\title{
Ambtshalve toepassing van rechtsgronden door de Nederlandse rechter
}

\author{
Daan Asser*
}

\section{Algemene beschouwingen over de taak van de rechter en de rolverdeling tussen rechter en partijen in het proces}

\section{I.I Inleiding}

De ambtshalve toepassing van rechtsgronden door de rechter was voor het laatst in I98I voorwerp van preadviezen en beraadslagingen in de afdeling privaatrecht van onze vereniging. ${ }^{1}$ Het onderwerp is blijkens recente discussie in de literatuur en nieuwe rechtspraak onverminderd actueel $^{2}$ en verdient na 34 jaar dan ook zeker een

* Prof. dr. W.D.H. Asser is hoogleraar burgerlijk procesrecht aan de Universiteit Leiden en oudraadsheer in de Hoge Raad.

I De preadviezen, getiteld 'Het ambtshalve aanvullen van rechtsgronden' waren van de hand van de Belgische preadviseurs E. Krings en B. Deconinck en de Nederlandse preadviseur T.A.W. Sterk en zijn gepubliceerd in TPR 1982 , p. 655-702.

2 Er is een grote hoeveelheid literatuur over dit onderwerp. Ik beperk me tot het noemen van de volgende sedert 2000 verschenen Nederlandse literatuur. Hierna worden de hier genoemde werken verkort aangehaald. A.G.F. Ancery, Ambtshalve toepassing van EU-recht (diss. Groningen), Serie Burgerlijk Proces \& Praktijk XIV, Deventer: Kluwer 20I2 - met een belangrijk deel over de huidige stand van zaken in het Nederlandse procesrecht; G. de Groot, Waarheidsvinding in het civiele (proces) recht, Preadvies Nederlandse Juristen-Vereniging, Deventer: Kluwer 20I2, hfdst. 3 en 4; zie ook de discussie n.a.v. het preadvies en vraagpunt 2 in: Waarheid en waarheidsvinding in het recht. Verslag van de op 8 juni 2012 te Rotterdam gehouden algemene vergadering van de Nederlandse Juristen-Vereniging (Handelingen Nederlandse Juristen-Vereniging 2012-2), Deventer: Kluwer 2013, p. 3I-49; R.H. de Bock, Tussen waarheid en onzekerheid: over het vaststellen van feiten in de civiele procedure (diss. Tilburg), Serie Burgerlijk Proces \& Praktijk, Deventer: Kluwer 20II, hfdst. 3; J. Ekelmans, De grenzen van het debat voor de civiele rechter in eerste aanleg, Deventer: Kluwer 2008; R.W.J. Crommelin, Het aanuullen van de rechtsgronden. De betekenis van art. 8:69 Awb in het licht van art. 48 (oud) Rv (diss. Leiden), Deventer: Kluwer 2007; C.E. Smith, Ambtshalve aanvullen van rechtsgronden, Ars Aequi Cahiers I4, Nijmegen: Ars Aequi Libri 2004. Van de handboeken en commentaren noem ik: E. Korthals Altes \& H.A. Groen, Mr. C. Assers Handleiding tot de beoefening van het Nederlands Burgerlijk Recht. Procesrecht. 7. Cassatie in burgerlijke zaken, Deventer: Kluwer 2015/204-208; H.J. Snijders, C.J.M. Klaassen \& G.J. Meijer, Nederlands burgerlijk procesrecht, Deventer: Kluwer 20II, nr. 42-5I, op een aantal punten uitgewerkt maar dan in de context van het hoger beroep in H.J. Snijders \& A. Wendels/H.J. Snijders, Civiel appel, Serie Burgerlijk Proces \& Praktijk 2, Deventer: Kluwer 2009, nr. 229-257; A.C. van Schaick, Mr. C. Assers Handleiding tot de beoefening van het Nederlands Burgerlijk Recht. Procesrecht. 2. Eerste aanleg, Deventer: Kluwer 20II/92-I00; A.I.M. van Mierlo, commentaar op art. 23, 24 en 25 in: A.I.M. van Mierlo \& C.J.J.C. van Nispen (red.), Tekst \& Commentaar Burgerlijke Rechtsvordering, Deventer: Kluwer 2014 (ook online); K. Teuben, Groene Serie Burgerlijke Rechtsvordering, art. 23, Deventer: Kluwer (online; bijgewerkt tot 22 oktober 2012); E.M. Wesseling-van Gent, Groene Serie Burgerlijke Rechtsvordering, art. 
nieuwe gedachtewisseling in de vereniging, temeer omdat in Nederland sindsdien het Wetboek van Burgerlijke Rechtsvordering belangrijke partiële vernieuwingsoperaties heeft ondergaan. In I988 is een nieuwe regeling van het bewijsrecht ingevoerd en in 2002 zijn algemene voorschriften in het wetboek gekomen en is de procedure in eerste aanleg vernieuwd. ${ }^{3}$

Wie wil denken en spreken over de taak van de rechter en de rolverdeling tussen rechter en partijen in het Nederlandse civiele proces, kan dat tegenwoordig niet meer doen binnen de veilige omheining van de tradities van het burgerlijk proces. Begrippen als partijautonomie en lijdelijkheid van de rechter die hier van oudsher als onwankelbare principes het kader bepaalden voor rechtsvinding en rechtstoepassing, verliezen langzamerhand die status. Zij zijn niet meer in alle opzichten vanzelfsprekend als gevolg van de ontwikkelingen in de maatschappij waardoor het civiele proces - in de betekenis van niet alleen de inrichting en het verloop van de individuele procedure maar ook van functie in de maatschappij als geheel - in toenemende mate wordt beschouwd als instrument van door wet en verdrag geboden rechtsbescherming waarop de burger aanspraak heeft (maar ook trouwens de overheid) en waarvoor de overheid verantwoordelijkheid draagt. Ik werk dat nu kort uit.

In de afgelopen eeuw is de maatschappij (de overheid) zich in toenemende mate de rechtsbescherming van individuele burgers en groepen burgers in hun onderlinge verhoudingen gaan aantrekken. De oorzaken en achtergronden daarvan behoeven hier niet te worden uitgemeten. In het algemeen kan men wel constateren dat het recht en ook het privaatrecht in steeds sterkere mate als instrument wordt gebruikt voor het bereiken van politieke en maatschappelijk gewenste doelen. De ontwikkeling van het privaatrecht is nog steeds voor een groot deel het resultaat van rechtspraak in individuele gevallen, maar rechtsbescherming als sociaal grondrecht brengt steeds meer privaatrechtelijke regelgeving mee om de realisering van dat grondrecht aan bepaalde groepen burgers te verzekeren en in individuele procedures de rechter te sturen teneinde die rechtsbescherming ook in die context te verwezenlijken. Daarnaast is het privaatrecht nog sterker dan vroeger een instrument in het kader van de economische ordening van de maatschappij. De principes van de gemeenschappelijke markt binnen de Europese Unie hebben ook naar het privaatrecht een uitstralende werking. In het procesrecht vindt die uitdrukking door toetsing van de mate van rechtsbescherming die een regel van nationaal procesrecht biedt aan het gelijkwaardigheidsbeginsel en aan het effectiviteitsbeginsel (doeltreffendheidsbeginsel) en doorbreking van nationale

24 en 25, Deventer: Kluwer (online; bijgewerkt tot I februari 2008). Verder noem ik G.C.C. Lewin, 'Ambtshalve toepassing van rechtsregels', TCR 20II, p. I2-I9; T.F.E. Tjong Tjin Tai, De rechterlijke vrijheid en de feitelijke grondslag, TCR 2002, p. 29 e.v.; E. Tjong Tjin Tai, 'Verrassingsbeslissingen door de civiele rechter', NJB 2000, p. 259 e.v.; W.D.H. Asser, H.A. Groen \& J.B.M. Vranken, m.m.v. I.N. Tzankova, Een nieuwe balans. Interimrapport Fundamentele herbezinning Nederlands burgerlijk procesrecht, Den Haag: Boom Juridische uitgevers 2003, hfdst. 6; W.D.H. Asser, H.A. Groen \& J.B.M. Vranken, m.m.v. I.N. Tzankova, Uitgebalanceerd. Eindrapport Fundamentele herbezinning Nederlands burgerlijk procesrecht, Den Haag: Boom Juridische uitgevers 2006, hfdst. 5 .

3 De Wet van 6 december 200 I tot herziening van het procesrecht voor burgerlijke zaken, in het bijzonder de wijze van procederen in eerste aanleg, Stb. 200I, 580, in werking getreden I januari 2002. De steeds geactualiseerde tekst van het Wetboek v. BRv is te vinden op http://wetten.overheid.nl/ BWBRoooI827 (geraadpleegd augustus 2015). 
processuele barrières op grond van het beginsel van effectieve rechtsbescherming door het EU-recht.

Een andere ontwikkeling is minstens van even groot belang. Onder invloed van de ontsporing van het recht als instrument in de hand van autoritaire, dictatoriale en misdadige regimes in de eerste helft van de twintigste eeuw is na de Tweede Wereldoorlog de 'rule of law' geïntroduceerd als algemeen principe in de verhouding tussen overheid en burgers: een burger heeft in een geschil met een andere burger of de overheid altijd recht op een onafhankelijke en onpartijdige rechter wiens beslissingen door de overheid worden gerespecteerd. De opkomst van voor de rechter afdwingbare grondrechten is sterk gestimuleerd door de Universele Verklaring van de Rechten van de Mens van 1948 en het daarop gebaseerde Europees Verdrag tot bescherming van de rechten van de mens en de fundamentele vrijheden. Het heeft wel even geduurd, maar na 65 jaar kan worden vastgesteld dat het EVRM een belangrijke constitutionele rechtsbron voor de dagelijkse rechtspraktijk is geworden. Daaraan heeft de rechtspraak van het Europese Hof voor de Rechten van de Mens in Straatsburg krachtig bijgedragen. Voor de dagelijkse procespraktijk vormt art. 6 EVRM - gemodelleerd naar art. Io van de Universele Verklaring van de Rechten van de Mens van 1948 - ook voor de civiele rechtspraak het vaste fundament voor een behoorlijke rechtspraak, een fair trial.

De rechtsvormende taak en praktijk van het Hof van Justitie hebben datzelfde gedaan voor de rule of law binnen de rechtssfeer van de Europese Unie, die vrij recent bovendien uitdrukking heeft gevonden in het Handvest van de grondrechten van de Europese Unie. Zo zijn processuele grondrechten in toenemende mate neergelegd in internationale verdragen en documenten van internationale organisaties.

De Nederlandse Grondwet kent wel bepalingen die de organisatie van de rechtspraak regelen, waaronder enige grondrechten op een behoorlijke rechtspraak, ${ }^{4}$ maar vooralsnog ontbreekt in de Grondwet een tweetal belangrijke grondrechten: het recht op toegang tot de rechter en het recht op een eerlijk proces, ${ }^{5}$ zodat daarvoor art. 6 EVRM en de rechtspraak van het EHRM in ons land de constitutionele basis vormen. ${ }^{6}$

4 Zoals in art. II6 Gw, dat bepaalt dat de inrichting, samenstelling en bevoegdheid van de rechterlijke macht bij wet worden geregeld en dat de wet aanwijst welke gerechten tot de rechterlijke macht behoren; art. II7 GW, dat de onafhankelijkheid waarborgt door benoeming van de leden van de rechterlijke macht voor het leven voor te schrijven; art. II2 en II3 Gw, die de rechterlijke macht de berechting van civiele geschillen respectievelijk strafzaken opdragen; en art. I2I Gw, dat de openbaarheid van behandeling en uitspraak alsmede de motivering van uitspraken verzekert.

5 Een Grondwetswijziging is voorgesteld om in de Nederlandse Grondwet het recht op toegang tot de rechter en op een eerlijk proces op te nemen. Zie het Rapport Staatscommissie Grondwet hfdst. 7.3.2 (www.rijksoverheid.nl/documenten/rapporten/20IO/II/II/rapport-staatscommissie-grondwet) en de internetconsultatie-wetsvoorstel tot wijziging van art. I7 Gw waarbij het recht op een eerlijk proces (en toegang tot de rechter) in de Gw wordt ingevoegd (www.internetconsultatie.nl/ eerlijkproces).

6 Via art. $93 \mathrm{Gw}$, op grond waarvan bepalingen van verdragen en van besluiten van volkenrechtelijke organisaties, die naar haar inhoud een ieder kunnen verbinden, verbindende kracht hebben en art. $94 \mathrm{Gw}$, dat de rechter voorschrijft wettelijke voorschriften buiten toepassing te laten indien deze toepassing niet verenigbaar is met een ieder verbindende bepalingen van verdragen en van besluiten van volkenrechtelijke organisaties. Daarbij moet worden aangetekend dat directe toetsing van de eigen wetten aan de Grondwet in Nederland is uitgesloten in art. I20 Gw, dat bepaalt dat de 


\section{I.2 Een eerlijk proces}

Het grote belang van art. 6 EVRM voor de bestudering van het civiele procesrecht is gelegen in de wezenlijke verandering van optiek die is ontstaan: de rechter is niet alleen de umpire in een wedstrijd tussen partijen om het gelijk (daarvan is in de praktijk nog heel vaak sprake) maar hij ${ }^{7}$ is ook en m.i. vooral verplicht ervoor te zorgen dat het proces zowel door zijn verloop als in de uitkomst de rechtsbescherming biedt die het recht belooft. Niet alleen het resultaat telt, ook de wijze waarop dat resultaat is bereikt. Een eerlijk proces is minstens zo belangrijk als een rechtvaardige uitkomst. Bij het spreken over de taak van de rechter is deze dimensie van belang. Zeker waar het onderwerp van dit preadvies meestal erg proces-technisch wordt benaderd, waarmee wordt bedoeld: het bewaken van de door de rechtspraak en doctrine geschapen onderscheiding tussen recht en feit, tussen feitelijke en juridische grondslagen van vordering en verweer, tussen petitum en gronden, tussen 'voorwerp' en 'oorzaak' van de vordering. Die onderscheidingen behoeven niet te worden verwezen naar de prullenbak maar moeten steeds worden gehanteerd in het kader van een eerlijk proces. Daarover nu een paar woorden meer.

Vijf waarborgen van een eerlijk proces spelen ten aanzien van de taakverdeling tussen partijen en rechter een rol. De eerste is het fundamentele recht van hoor en wederhoor of het fundamentele beginsel van tegenspraak (contradictoir beginsel), en het tweede daarmee verwante is het recht op gelijke behandeling (equality of arms). Deze beide vindt men in het Nederlandse wetboek terug in art. I9 Rv: 'De rechter stelt partijen over en weer in de gelegenheid hun standpunten naar voren te brengen en toe te lichten en zich uit te laten over elkaars standpunten en over alle bescheiden en andere gegevens die in de procedure ter kennis van de rechter zijn gebracht, een en ander tenzij uit de wet anders voortuloeit. Bij zijn beslissing baseert de rechter zijn oordeel, ten nadele van een der partijen, niet op bescheiden of andere gegevens waarover die partij zich niet voldoende heeft kunnen uitlaten.' De derde waarborg van een eerlijk proces is het recht op een onpartijdige rechter. Gevaar voor verlies van onpartijdigheid ligt op de loer waar de rechter zich actief gaat bemoeien met de grondslagen van vordering respectievelijk verweer van partijen, met de 'middelen' die zij in stelling brengen om de zaak te winnen. De rechter die op dat punt gaat 'meeprocederen' brengt zijn onpartijdigheid in gevaar, nog daargelaten dat hij het recht op hoor en wederhoor en gelijke behandeling veronachtzaamt als hij zijn eigen weg gaat en zich afsluit voor de mening van partijen. De vierde waarborg is het recht op inzicht in de gronden waarop de rechter de zaak beslist, meer gebruikelijk geformuleerd als de motiveringsplicht van

rechter niet treedt in de beoordeling van de grondwettigheid van wetten en verdragen. De meest recente poging om via grondwetswijziging een (tot een aantal grondrechten beperkt) toetsingsrecht in te voeren, het in eerste lezing door de Staten-Generaal aangenomen initiatief-wetsvoorstel Van Tongeren (nr. 32 334), is in tweede lezing uiteindelijk in maart van dit jaar vastgelopen in de Tweede Kamer, omdat daarin de grondwettelijk voorgeschreven tweederde meerderheid niet meer aanwezig bleek te zijn. Zie Handelingen Tweede Kamer 5 maart 20I5, 60-II-I e.v. De belangrijkste Nederlandse monografie over art. 6 EVRM in in het civiele proces is P. Smits, Artikel 6 EVRM en de civiele procedure, Serie Burgerlijk Proces \& Praktijk Io, tweede druk, Deventer: Kluwer 2008.

7 Ter voorkoming van misverstand over de vereiste gender neutrality: hier en verder wordt uitsluitend met het oog op het woordgeslacht van 'rechter' de mannelijke vorm van het voornaamwoord gebruikt. 
de rechter, vastgelegd in art. 230 lid I, aanhef en onder e Rv. De verantwoording die de rechter aflegt in zijn motivering van de beslissing laat zien op welke gegevens hij zijn beslissing baseert, waar hij die gegevens vandaan heeft, wat partijen daarover naar voren hebben gebracht en hoe hij daarop reageert. De Hoge Raad hanteert als criterium voor een behoorlijke motivering dat elke rechterlijke beslissing ten minste zodanig dient te worden gemotiveerd dat zij voldoende inzicht geeft in de aan haar ten grondslag liggende gedachtegang om de beslissing zowel voor partijen als voor derden - in geval van openstaan van hogere voorzieningen: de hogere rechter daaronder begrepen - controleerbaar en aanvaardbaar te maken. ${ }^{8}$ De vijfde waarborg is de verplichting van de rechter om uitspraak te doen op basis van de werkelijke feiten. Het recht op presentatie van bewijs en het recht op tegenspraak tegen de door de wederpartij in het geding gebrachte bewijsmiddelen zijn al eeuwen deel van ons civiele procesrecht, zijn ook verankerd in onze wetgeving (art. I9 Rv en de bepalingen over bewijsrecht) en liggen bovendien volgens de rechtspraak van het EHRM besloten in de equality of arms. ${ }^{9}$ De Hoge Raad spreekt in dit verband al lang van 'het algemene maatschappelijke belang van de waarheidsvinding in rechte'. ${ }^{\text {Io }}$ Waarheidsvinding is kortom een beginsel van procesrecht. ${ }^{\text {II }}$ Het verband met ons onderwerp springt misschien niet dadelijk in het oog, maar sprekend over de taakverdeling tussen partijen en rechter kan men niet voorbijzien aan de implicaties van dat beginsel voor de beoordeling van de vraag in hoeverre de rechter bevoegd is te interveniëren met betrekking tot de door de partijen gestelde feitelijke grondslagen van vordering en verweer, tenminste indien de in de betrokken zaak de actuele rechtsbescherming die het recht beoogt te bieden een dergelijke interventie verlangt. ${ }^{\mathrm{I}}$

\section{I.3 De actieve rechter}

Voor een goede beoordeling van de wijze waarop de Nederlandse rechter zijn taak ten opzichte van partijen ziet en uitoefent, is het nodig kort aandacht te besteden aan de sterk toegenomen actualiteit van de inrichting van het civiele proces en de daarmee samenhangende actieve rol van de rechter. Een zeer korte schets volgt hier.

Werd het verloop van het civiele proces lange tijd beheerst door de activiteit (of inactiviteit) van partijen, sinds de jaren zeventig van de vorige eeuw heeft de rechter een steeds actievere rol gekregen in de sturing van het proces. In het familierecht van Boek I BW werd in 1970 als de gewone procesvorm ingevoerd de verzoekschriftprocedure (Boek I, Titel $3 \mathrm{Rv}$ ). Die procedure wordt ingeleid met een verzoekschrift aan de rechter, waarna de verweerder een verweerschrift kan indienen en vervolgens een mondelinge behandeling van de zaak wordt gehouden. De rechter beschikt over meer processuele bevoegdheden dan de rechter in

8 Standaard sinds HR 4 juni I993, NJ I993/659 (m.nt. D.W.F. Verkade) (Vredo/Veenhuis).

9 Smits 2008, 3.3.4 en 3.4.3; De Bock 20II, 2.5; De Groot 20I2, 3.7.I.

Io Zie bijvoorbeeld HR II juli 2008, NJ 2009/45I (m.nt. E. J. Dommering), 3.4.6; HR io april 2009, NJ 20Io/47I (m.nt. C.J.M. Klaassen), 3·3; HRI8 april 20I4, NJ 2015/20 (m.nt. M.M. Mendel en H.B. Krans).

II De Bock 20II, 2.6.

I2 Zie over de waarheidsvinding in verband met de rolverdeling tussen rechter en partijen vooral De Bock 20II, hfdst. 3 en De Groot 20I2/4.7.I-4.7.4. 
de gewone, door een dagvaarding ingeleide procedure (de dagvaardingsprocedure). Sindsdien kent Nederland twee volwaardige procesvormen naast elkaar. In de van oudsher bestaande procedure die met een door de ene partij aan de andere uitgebrachte dagvaarding aanvangt (de dagvaardingsprocedure) worden met name de vermogensrechtelijke geschillen behandeld en beslist. De zeggenschap van partijen over het procesverloop is groter maar sinds de jaren tachtig van de vorige eeuw is de rol van de rechter gaandeweg sterker geworden, met name door de opkomst van de mondelinge behandeling van de zaak na het antwoord van de gedaagde, de comparitie na antwoord.

Sinds de wetswijziging van 2002 kennen wij een zeer actieve rechter die de procesgang in hoge mate bepaalt, daartoe ondersteund door landelijke procesreglementen en andere regelingen die zijn opgesteld door de Rechtspraak. ${ }^{13}$ Is in de verzoekschriftprocedure de mondelinge behandeling van de zaak - na indiening van het verzoekschrift en verweerschrift - de plaats waar de rechter met de partijen spreekt en zo nodig aanvullende informatie vraagt, getuigen en deskundigen hoort, in de dagvaardingsprocedure spreekt de rechter met partijen tijdens de comparitie na antwoord (art. I3I Rv). Daar zetten partijen op vragen van de rechter hun standpunten uiteen, mogen advocaten (meestal kort) nog de standpunten toelichten - echt uitvoerig pleiten komt nog maar weinig voor - en probeert de rechter te bereiken dat partijen de zaak schikken, wat vaak gebeurt. Zo nodig voert de rechter de regie over het verdere verloop van de procedure door daarover met partijen afspraken te maken, bijvoorbeeld over bewijslevering door getuigen of een deskundigenonderzoek. In hoger beroep kent de verzoekschriftprocedure hetzelfde model als in eerste aanleg. De dagvaardingsprocedure kent geen comparitie na antwoord, wel een pleitzitting (die ook als comparitie kan worden gebruikt) maar deze wordt lang niet altijd gehouden. Verder wordt in veel gevallen een comparitie na aanbrengen van de zaak in appel gehouden. Dat geschiedt nog voordat de appellant zijn bezwaren (grieven) in de daartoe bestemde memorie van grieven naar voren heeft gebracht en de verweerder ('geïntimeerde') zijn verweer in appel heeft gevoerd. De comparitie na aanbrengen dient om op basis van het debat en de uitspraak van de rechter in eerste aanleg te bezien of de zaak niet alsnog geschikt kan worden. Dat gebeurt in veel gevallen.

Deze ontwikkelingen zijn niet afgerond. Op het moment dat dit wordt geschreven (augustus 2015) is in het kader van het project KEI (Kwaliteit en Innovatie rechtspraak) bij de Eerste Kamer van de Staten-Generaal een wetsvoorstel aanhangig waarbij de civiele procedure niet alleen wordt gedigitaliseerd maar ook wordt vereenvoudigd. ${ }^{14}$ De twee verschillende procesvormen worden vervangen door één procesmodel dat door een verzoekschrift wordt ingeleid - zij het dat het onderscheid tussen verzoek (regel in de familiezaken) en vordering (vermogenszaken)

Zie voor deze regelingen www.rechtspraak.nl/Procedures/Landelijke-regelingen/Pages/default. aspx (geraadpleegd augustus 2015).

I4 Wetsvoorstel Wijziging van het Wetboek van Burgerlijke Rechtsvordering en de Algemene wet bestuursrecht in verband met vereenvoudiging en digitalisering van het procesrecht, Kamerstukken II 20I4/15, 34 059, zie voor de teksten https://zoek.officielebekendmakingen.nl/dossier/34059 (geraadpleegd augustus 2015). Zie over het project KEI www.rijksoverheid.nl/onderwerpen/rechtspraak-en-geschiloplossing/vernieuwing-in-de-rechtspraak/programma-kwaliteit-en-innovatie-rechtspraak-kei (geraadpleegd augustus 20I5). 
blijft bestaan. Na een verweerschrift volgt een centrale mondelinge behandeling, waarop ook bewijslevering kan plaatsvinden.

Een steeds actiever geworden rechter is niet alleen een uitvloeisel van het streven naar meer efficiëntie en snelheid in het proces, maar ook een product van een sterk gegroeid besef dat de rechter een eigen verantwoordelijkheid heeft voor de inhoudelijke procesvoering in het kader van de zorg voor een eerlijk proces en voor de inhoudelijke basis van zijn beslissing en dat hij niet meer alles op zich laat afkomen en dan beslist - de overheersende houding van de civiele rechter veertig jaar geleden.

In ditverband kan, bij wijze van intermezzo, ook gewezen worden op de invloed van het kort geding op de attitude van de Nederlandse civiele rechter. De grote vlucht die het kort geding bij de voorzieningenrechter van de rechtbank sinds de jaren zeventig van de vorige eeuw in ons land heeft genomen en met name de ruime bevoegdheid die de kortgedingrechter, onder het wakend oog van de Hoge Raad, zich toemeet, is een niet onbelangrijke factor geweest. Heel veel zaken die anders door de rechtbank zouden zijn behandeld, vonden en vinden hun weg naar het kort geding. Het procesmodel van het kort geding is heel eenvoudig, de klemtoon ligt op de behandeling ter zitting. Het formele bewijsrecht behoeft niet te worden toegepast. De rechter schikt de zaak of beslist vervolgens bij vonnis op basis van door partijen gestelde feiten die hem 'aannemelijk' voorkomen. Daarbij komt dan nog dat van het vonnis van de president van de rechtbank hoger beroep openstaat bij het hof en vervolgens cassatie van de uitspraak van het hof (het karakter van kort geding blijft weliswaar steeds behouden). Ook hele principiële kwesties worden in kort geding berecht en omdat over principiële rechtsbeslissingen door hof en Hoge Raad kan worden geoordeeld, ontstaat op dat punt precedentwerking. Deze informele en snelle rechtsgang is zeer succesvol gebleken en dat heeft de minder formele attitude van de rechter in de bodemprocedure voor een deel bepaald. De houding van de rechter op de comparitie na antwoord ${ }^{15}$ heeft geregeld veel weg van die van de rechter in kort geding.

\section{I.4 Partijautonomie en lijdelijkheid}

De taakvan de rechter en de rolverdeling tussen rechter en partijen in het civiele proces worden in belangrijke bepaald door de maatschappelijke visie op de doelstellingen van het civiele proces en de verwachtingen die in de maatschappij leven ten aanzien van de civiele rechtspraak in het algemeen. In onze westerse democratische rechtstaat geldt als uitgangspunt dat de burgers vrij zijn om hun onderlinge - privaatrechtelijke - rechtsbetrekkingen zelf te bepalen. Dit brengt mee dat zij zelf kunnen beschikken over hun rechten en verplichtingen en over de rechtsgevolgen die het recht aan bepaalde feiten verbindt. In het verlengde van deze autonomie van de burger ligt dat burgers hun geschillen over die rechtsgevolgen ook zelf kunnen regelen en dat indien

I5 Zie over de civiele zitting Janneke van der Linden, De civiele zitting centraal: informeren, afstemmen en schikken (diss. Tilburg), Serie Burgerlijk Proces \& Praktijk VIII, Deventer: Kluwer 20Io; voor de comparitie na antwoord W. Heemskerk, Groene Serie Burgerlijke Rechtsvordering art. I3I, Deventer: Kluwer (online; bijgewerkt tot II september 2013). Informatief is de door de Rechtspraak opgestelde Handleiding regie vanaf de conclusie van antwoord, 2009, te vinden op www.rechtspraak.nl/Procedures/Landelijke-regelingen/Sector-civiel-recht/Documents/Handleidingregievanafdeconclusievanantwoord2eversieseptember2009.pdf (geraadpleegd op I4 augustus 2015). 
en voorzover zij daarin niet slagen en de tussenkomst van de overheidsrechter inroepen om hun geschil te beslissen, deze de omvang van het te beslissen geschil zoals de partijen dat ter beslissing hebben voorgelegd, heeft te respecteren. In dit verband wordt het begrip partijautonomie in het civiele proces gebruikt, met als spiegelbeeldig begrip de 'lijdelijkheid' van de rechter. ${ }^{16}$ Als het gaat om de omvang van het geschil is er weinig reden om het principe waarvoor het begrip partijautonomie in dat verband staat, ter discussie te stellen: de inzet van het proces behoort niet aan de rechter maar aan de partijen. Dit uitgangspunt bij de rolverdeling in het civiele proces geldt in $\mathrm{Ne}-$ derland, België en alle democratische landen. ${ }^{17}$ Maar dat is de buitengrens. De echte autonomie in het privaatrecht is overigens wel behoorlijk teruggedrongen, zoals is aangestipt in § I.I, tot een niveau dat men vraagtekens kan zetten bij het gebruik van het woord partijautonomie, voor wat daaronder pleegt te worden verstaan.

Als we al uitgaan van autonomie van partijen bij het bepalen van de inzet van de procedure, de omvang van het geschil, doen zij dat niet zo heel vaak in gezamenlijk overleg. Dat is natuurlijk geen nieuw gezichtspunt, integendeel. Heel veel processen worden nolens volens gevoerd omdat partijen mijlenver uit elkaar liggen, hun geschil dus niet onderling oplossen en de rechter nodig hebben om de knoop door te hakken (of de schikking alsnog te bewerkstelligen), om te zwijgen van de processen waarin partijen elkaars gezworen vijanden zijn, zoals bijvoorbeeld in zeer contentieuze geschillen over alimentatie. Partijautonomie is dus ook in zoverre een relatief begrip. Het dient vooral de individuele partij en haar positie en niet het zoeken naar een gezamenlijke oplossing bij de rechter. Bij het zoeken naar een schikking onder leiding van de rechter staat de in het proces spelende partijautonomie niet centraal en wordt zelfs impliciet gevraagd die opzij te zetten, ook al berust het accepteren van een schikking zonder enige twijfel juist op de privaatrechtelijke autonomie van partijen om een einde te maken aan het geschil, zoals partijen ook het recht hebben dat te doen door middel van arbitrage, bij een vaststellingsovereenkomst (art. 7:900 $\mathrm{BW}$ - al of niet in de vorm van bindend advies - of door middel van mediation. In het civiele proces verdraagt het hameren op processuele partijautonomie zich slecht met de gedachte dat de procesvoering een door partijen en rechter samen gedragen verantwoordelijkheid is.$^{18}$ Maar ook als men dit laatste te ver vindt gaan, valt in elk geval te betwijfelen of partijautonomie, vanwege het individuele, particuliere belang bij het winnen van de zaak dat daarmee gediend is, in meer algemene zin de kwaliteit en de rechtvaardigheid van proces en uitspraak bevordert en dus de maatschappelijke vrede (maatschappelijk belang bij rechtvaardige beslissingen). ${ }^{19}$

I6 Kritisch over dit begrip Asser, Groen \& Vranken 2003, hfdst. 6; en over de (veelal afwijzende) reacties daarop Asser, Groen \& Vranken 2006, hfdst. 5, i.h.b. 5.4. Krachtig protagonist van de partijautonomie is Van Schaick 20II/92-Ioo en eerder in A.C. van Schaick, Het burgerlijk recht de baas? Over de verwevenheid van burgerlijk recht en burgerlijk procesrecht (oratie Tilburg), Deventer: Kluwer 2009; genuanceerd De Bock 20II, hfdst. 3, en De Groot 20I2/4.7.I-4.7.4.

I7 Een mooie klassieke verhandeling over dit onderwerp, waarin Engels en Frans recht worden vergeleken, is te vinden in J.A. Jolowicz, On Civil Procedure, Cambridge: 2000, hfdst. Io: 'Da mihi factum dabo tibi ius: a problem of demarcation in English and French law' (gebaseerd op een eerder artikel van zijn hand).

I8 Zie daarover hierna in hoofdstuk 5 .

I9 In deze zin De Groot 20I2/4.7.I, sprekend over partijautonomie in verhouding tot de waarheidsvinding en het daaraan ten grondslag liggende algemene maatschappelijke belang van de waarheidsvinding in rechte, hierboven in $§$ I.2 als vijfde genoemde waarborg van een eerlijk proces. 
Waar de privaatrechtelijke autonomie is ingeperkt door materiële dwingende rechtsregels, al of niet van openbare orde, werkt ook die inperking door in de procesrechtelijke bevoegdheden, niet omdat partijen in principe minder bevoegdheden zouden hebben, maar omdat daarnaast - dus niet zozeer daartegenover - de rechter meer bevoegdheden heeft en in voorkomend geval verplichtingen om in verband met ambtshalve toe te passen rechtsregels met het oog op die toepassing ook het debat over en het onderzoek naar de feiten ambtshalve uit te breiden. Een sprekend actueel voorbeeld is het gebied van de consumentenbescherming die wordt geboden door Richtlijn 93/13/EEG van de Raad van 5 april 1993 betreffende oneerlijke bedingen in consumentenovereenkomsten. Wij komen daarop hieronder in $\S 3 \cdot 4 \cdot 7 \cdot 3$ terug.

\section{$2 \quad$ Feit en recht ${ }^{20}$}

\section{I Inleiding}

Bij de bespreking van de problematiek van de rolverdeling van de rechter en de partijen in het proces kan een beschouwing over de verhouding tussen recht en feit niet ontbreken. Ons onderwerp wordt immers beheerst door de in ons recht bestaande dichotomie tussen feit en recht. Daarop is een krachtige logica gebouwd die tot uitdrukking komt in het klassieke syllogisme van de rechtsregel als maior, de feiten als minor en een conclusie bestaande uit de rechtsgevolgen die de maior verbinden aan de minor. De normatieve rechtsregel is zo opgebouwd en bijgevolg ook het rechterlijk vonnis. ${ }^{21}$ Het is de basis voor ons procesmodel waarop ook de inrichting van het proces is gebouwd: eerst de aandacht voor de feiten (stellen en bewijzen door partijen); als de feiten door de rechter zijn vastgesteld, volgt de rechtstoepassing door de rechter in zijn uitspraak. Voor de rechtsvinding (het bepalen van de inhoud van de maior) is dit model niet bruikbaar, daarvoor was het ook niet bedoeld. Als beslissingsmodel - model voor het vormen van het oordeel - is het evenmin altijd bruikbaar, want de rechter wordt vaak gevraagd zelf de maior vorm te geven vanuit een op grond van zijn waardering van de feiten (minor) opgebouwd oordeel. Maar in de opbouw van de uitspraak in onze rechtspraaktraditie is het nog springlevend. Dat wil niet zeggen dat de manier waarop uitspraken worden gemotiveerd niet anders zou moeten, waardoor meer inzicht zou worden verkregen in het rechtsvindings- en beslissingsproces dat aan de uitspraak ten grondslag ligt. Misschien zouden we zelfs verlost worden van veel van de problematiek die onderwerp is van dit preadvies als de civiele rechter gewoon wat duidelijker zou zijn over zijn beweegredenen om wat meer door hem juist gevonden orde te scheppen in de door partijen in hun onderlinge strijd soms bijeengerommelde 'rechtsstrijd'. De later (in § 3.4.4) te bespreken rechtspraak van de Hoge Raad laat zien dat hij de rechter daartoe ook de ruimte biedt.

20 Zie hierover vooral Smith 2004.

2I Hier en hierna spreek ik, uitsluitend ter wille van de leesbaarheid, meestal over vonnis, vordering en eiser, terminologie die behoort bij de dagvaardingsprocedure. De in de verzoekschriftprocedure daarvoor gebruikte termen zijn beschikking, verzoek en verzoeker. Met betrekking tot ons onderwerp is het maken van onderscheid in principe niet nodig. 
Ons onderwerp wordt ook behoorlijk gecompliceerd door het onderscheid tussen recht en feit. Het is vooral de natuurlijke interactie van feiten en recht in het proces die daarvan de oorzaak is. Door die interactie kan geheel onduidelijk worden wat feit is en wat recht, met name in de gevallen dat de feiten de inhoud van de norm bepalen, zoals bij de toepassing van open normen die zelfs bij de meest strakke rechtsregels het beeld kunnen verstoren. Denk aan de derogerende werking van de redelijkheid en billijkheid (art. 6:2 lid 2 BW en art. 6:248 lid 2 BW) die zelfs de meest harde contractsnorm op losse schroeven kan zetten. Bovendien kan het verloop van het debat tussen partijen meebrengen dat feiten die door partijen als niet relevant werden beschouwd, door de rechter als wel van (mogelijke) betekenis worden beoordeeld en in het gesprek met partijen op een comparitie aan de orde worden gesteld.

Een tweede complicerende factor is dat partijen in de weg die uiteindelijk heeft geleid tot een proces niet steeds met het oog op hun rechtspositie in een eventueel proces met elkaar hebben gecommuniceerd en ook niet altijd de invalshoeken en uitgangspunten hebben gekozen die later beslissend zouden blijken te zijn in het proces. De latere procesdoelen zijn niet steeds al vanaf het begin gedefinieerd en uitgewerkt. Misschien is dat nog wel het geval bij geruchtmakende ongevallen waardoor ook juristen meteen inspringen en de gevolgen voor hun bij het ongeval betrokken cliënten - veroorzakers of slachtoffers - netjes rubriceren en de discussie ordelijk laten verlopen met het oog op aansprakelijkheid en schadeverhaal. Maar ook dan kan er bijvoorbeeld onduidelijkheid bestaan over de stand van het recht (denk aan een tot dusver onbekende technische problematiek die zich heeft voorgedaan ${ }^{22}$ ) en worden er keuzen gemaakt die uiteindelijk niet goed overeenkomen met de gestelde procesdoelen als het op procederen aankomt en de rechter zich ermee gaat bemoeien.

Het voorgaande zou tot terughoudendheid moeten manen waar het gaat om het onderscheid tussen feit en recht en het handhaven van daarop gebouwde aloude principes en uitgangspunten voor de inrichting van het proces en de rolverdeling tussen partijen en rechter. De erkenning van de interactie tussen recht en feit is vruchtbaar voor de rechtsvorming en voor het bereiken van een rechtvaardige beslissing. Zij bevordert de waarheidsvinding en een open verhouding tussen de partijen en de rechter die hun geschil beslist waardoor verrassingen worden voorkomen en de voorspelbaarheid van de rechterlijke beslissing wordt vergroot. De rolverdeling tussen rechter en partijen wordt steeds meer bepaald door de regels van een eerlijk proces.

\subsection{Feiten en rechtsfeiten}

Partijen verstrekken in een proces alle soorten feitelijke informatie, in het gebruikelijke jargon 'feiten en omstandigheden': gebeurtenissen, situaties en relaties, waarnemingen, opvattingen, interpretaties en meningen, voorwerpen, eigenschappen, samenstellingen enz. Zij kunnen in het dagelijks leven een bepaalde juridische betekenis hebben, maar ook helemaal niet. Zij kunnen een bijzondere betekenis krijgen in een geschil en vervolgens in een daarover gevoerd proces. Al naar gelang

22 Zoals in het geval van de verschoven veendijk te Wilnis in HR I7 december 20I0, NJ 20I2/I55 (m.nt. T. Hartlief) (Hoogheemraadschap Amstel, Gooi en Vecht/Gemeente De Ronde Venen). 
die betekenis hebben zij in het proces - als ik me daartoe beperk - een bepaalde juridische status. Processtukken van een partij bevatten vaak veel feitelijke informatie van diverse aard. Maar niet alle informatie vormt de basis voor de door die partij ingenomen standpunten in het proces. Althans de juridisch relevante basis. Partijen maken een keuze uit de feiten waarop zij hun uiteenlopende processuele-juridisch relevante - standpunten baseren met het oog op de beslissing die elk van hen van de rechter verlangt. Zoals hierboven in $\$ 2$.I in algemene termen is uiteengezet aan de hand van het door de logica gegeven model van het syllogisme, geeft die rechterlijke beslissing in de kern het antwoord op de vraag of die door de eiser gestelde feiten naar het oordeel van de rechter leiden tot het door de eiser op grond van die feiten ingeroepen rechtsgevolg: verplicht het door de eiser aan de verweerder verweten en als onrechtmatig gekwalificeerde gedrag de verweerder tot de vergoeding van de schade die eiser stelt te hebben geleden als gevolg van die onrechtmatige daad? In dit verband is het begrip rechtsfeit van belang. ${ }^{23}$ Men kan met Scheltema het rechtsfeit omschrijven als het feit waaraan het recht gevolgen verbindt of met Meijers als de omstandigheid van wier bestaan de toepassing van een rechtsregel afhankelijk is. Een rechtsregel vindt toepassing op feiten die voldoen aan het in de regel gedefinieerde feit. Wat wij 'rechtsfeit' noemen bestaat meer dan eens uit een complex van feiten en omstandigheden die tezamen het rechtsfeit opleveren. Alle feiten die voldoen aan de in de rechtsregel opgenomen omschrijving van het feit waaraan de regel gevolgen verbindt, ${ }^{24}$ zijn dus te kwalificeren als rechtsfeiten.

$\mathrm{Nu}$ kunnen die feiten zelf al bestaan uit een juridisch gedefinieerde feitelijke omschrijving, zoals de omschrijving van hoedanigheden van personen zoals 'eigenaar', 'huurder', 'moeder', 'ouders', 'afzender', 'vervoerder' enz. ${ }^{25}$ Het zijn van ouder is een rechtsfeit voor de toepassing van bepaalde regels van familierecht. Zo kan men ook juridisch gedefinieerde verhoudingen en rechten als rechtsfeiten aanmerken, zoals huwelijk, nationaliteit, eigendom, bezit. In ons recht is het feitelijk karakter van 'rechten' uitdrukkelijk in het bewijsrecht erkend in art. I49 Rv, art. I50 Rv en I87 Rv: 'rechten' zijn voor bewijs vatbaar. ${ }^{26}$

Een intermezzo: het begrip 'feit'. Bij deze stand van zaken heeft het begrip 'feit' in het algemeen voor het procesrecht weinig effectief onderscheidend vermogen. Dat heeft het zelfs niet voor die tak van rechtspraak waarin feitelijk en juridisch zo streng mogelijk gescheiden zijn: de cassatierechtspraak. Wat daar 'feitelijk' is en dus niet vatbaar voor toetsing door de cassatierechter, wordt niet enkel bepaald door de 'feiten' (whatever that may be) maar vooral door wat de Hoge Raad aan

23 Zie over rechtsfeiten onder meer T.F.E. Tjong Tjin Tai 2002, p. 29 e.v.; Smith 2004/2.2.2 en 2.2.3 (in verband met de taakverdeling tussen partijen en rechter); De Bock 20II/3.8; De Groot 20I2/4.2.I.

24 De minor in het syllogisme waarin de rechtsregel de maior vormt en het rechtsgevolg de conclusio.

25 Met name Boek 8, Titel I BW bevat een groot aantal definities van feitelijke begrippen.

26 En in art. $187 \mathrm{Rv}$ : Het verzoekschrift [tot het houden van een voorlopig getuigenverhoor] houdt in:

a. de aard en het beloop van de vordering;

b. de feiten of rechten die men wil bewijzen;(enz.).

De voorheen gevoerde discussie of rechten voor bewijs vatbaar zijn, is verstomd na de beschouwingen van de minister in de memorie van antwoord bij het in I988 wet geworden wetsvoorstel Io 377. Zie G.R. Rutgers, R.J.C. Flach \& G.J. Boon, Parlementaire geschiedenis van de nieuwe regeling van het bewijsrecht in burgerlijke zaken. Perlementaire stukken systematisch gerangschikt, Deventer: Kluwer I988, p. 8o-8I. 
de feitenrechter ter beoordeling en bijgevolg voor diens rekening laat. ${ }^{27}$ Men zal dan ook in het procesrecht naar gelang van de processuele functie moeten vaststellen wat in het proces 'feitelijk' is en wat behoort tot het 'recht', in concreto: de op de rechtsfeiten toe te passen rechtsregel. Als het gaat om het bewijs, de waarheidsvinding, kiest De Bock, ${ }^{28}$ naar ik meen op grond van de bovenstaande beschouwingen waarbij ik in essentie heb aangesloten bij haar betoog, terecht voor een zuiver functioneel feitbegrip. Zij concludeert dat alles wat geen recht is, feit is. Ik ben het met haar eens dat deze conclusie ook geldt voor de rolverdeling tussen partijen en rechter waarover dit preadvies gaat. Recht wordt gevormd door de rechtsregels die de rechter moet toepassen bij de beslissing van geschillen. Wat niet in deze zin als recht kan worden gekwalificeerd, behoort tot het domein van de 'feiten'.

Terug naar het rechtsfeit. Als begrip is het gekoppeld aan de rechtsregel en staat het daarom in principe los van het proces. Maar in het proces krijgt het meestal pas concrete betekenis. Vordering en verweer zijn gebaseerd op door de (onderscheiden) partijen toepasselijk geachte rechtsregels en op de feiten die zij voor die toepassing noodzakelijk achten en daarom hebben gesteld. De eiser zal zijn vordering baseren op naar de ingeroepen rechtsnorm gekwalificeerde feiten, de rechtsfeiten, of in processueel jargon: de feitelijke gronden van de eis. Ook de verweerder kan zich op rechtsfeiten baseren, namelijk indien hij feiten aanvoert die leiden tot een zelfstandig rechtsgevolg dat de door de eiser ingeroepen normtoepassing blokkeert. Ik noem er drie: (a) het rechtsfeit dat de door de eiser gestelde verbintenis tot betaling van de koopsom is tenietgegaan doordat, anders dan de eiser beweert, betaling heeft plaatsgevonden; (b) het rechtsfeit dat het vorderingsrecht waarop de eis is gebaseerd is verjaard (waartoe de verweerder als rechtsfeiten zal moeten stellen dat de verjaringstermijn op een bepaald moment is ingegaan en vervolgens is verstreken); (c) rechtsfeiten die een andere kwalificatie van de door de eiser gestelde rechtsfeiten meebrengen waardoor de door de eiser ingeroepen norm zich niet voor toepassing leent: bijvoorbeeld de eiser stelt een huurovereenkomst maar de verweerder stelt dat het gaat om een gebruiksovereenkomst om niet. Of de verweerder stelt feiten waaruit naar voren komt dat de door eiser gestelde feiten niet de door eiser daaraan gegeven kwalificatie rechtvaardigt, bijvoorbeeld dat zijn gedrag in de gegeven omstandigheden niet onzorguuldig en onrechtmatig was. Wij noemen dit in Nederland een 'bevrijdend verweer'. Op grond van de hoofdregel van art. I50 Rv leidt dat tot bewijslast voor de gedaagde. ${ }^{29}$

Echter: de feiten die de verweerder enkel ter betwisting van de waarheid van de door eiser gestelde rechtsfeiten aanvoert, zoals feiten die, indien waar, de onwaarheid van de door de eiser gestelde rechtsfeiten zouden meebrengen, ${ }^{30}$ of die het in-

27 Zie over de relatie tussen art. 79 RO en art. 25 Rv E. Korthals Altes \& H.A. Groen 2015/204.

28 R.H. de Bock 20II/I.3.

29 Het is het equivalent van de regel in België m.b.t. de subjectieve bewijslast: reus excipiendo fit actor, art. I3I5 lid 2 BW, een bepaling die gelijk is aan art. I3I5 van de Franse Code civil. Zij kwam dan ook eveneens voor - in een bewerkte vorm - in het oude Nederlandse art. 1302 BW.

Een voorbeeld daarvan geeft HR 23 oktober I992, NJ I992/8I3. 
treden van het rechtsgevolg verhinderen, zou ik geen rechtsfeiten willen noemen ${ }^{3 \mathrm{I}}$ als zij niet verbonden zijn aan enig door de verweerder ingeroepen zelfstandig (bevrijdend) rechtsgevolg.

Ging het hiervoor vooral over een a priori gedefinieerd rechtsfeit, aandacht verdient de dynamiek van het rechtsfeit in het proces. In het proces moet worden uitgemaakt of de enerzijds gestelde en anderzijds betwiste feiten door de rechter moeten worden aangemerkt als feiten waaraan het door de stellende partij ingeroepen rechtsgevolg is verbonden door de in het gegeven geval toepasselijke rechtsregel, dus of zij rechtsfeiten zijn (afgezien van de vaststelling van die feiten - een bewijsvraag). In veel gevallen levert dit weinig problemen op en gaat het enkel om interpretatie van het als rechtsfeit gepresenteerde feit (feitencomplex). Maar er zijn ook gevallen waarin onduidelijk is of de ingeroepen rechtsregel en de rechtsgevolgen die deze in het vooruitzicht stelt, op het gegeven geval van toepassing zijn, zodat de vraag rijst of de gestelde feiten wel kunnen worden gekwalificeerd als in die rechtsregel omschreven. Een voorbeeld is de vraag of het door de eiser gewraakte gedrag van de gedaagde als onrechtmatige daad kan worden gekwalificeerd of dat de door de eiser gestelde schade waarvan hij van de gedaagde vergoeding vordert wel kan worden aangemerkt als het volgens die rechtsregel vereiste gevolg van dat gedrag, of dat het door de eiser aan de gedaagde verweten gedrag wel volgens die rechtsregel aan de gedaagde kan worden toegerekend (verweten). Dan bestaat dus in het proces onzekerheid over de vraag welke van de door de eiser met betrekking tot de onrechtmatigheid, causaliteit of toerekenbaarheid gestelde feiten zich lenen voor de kwalificatie die nodig is voor het intreden van het door de rechtsregel in het vooruitzicht gestelde rechtsgevolg. Of alle gestelde feiten rechtsfeiten zijn, staat in zo'n geval niet a priori vast. Maar aangenomen kan worden dat in de processuele context als rechtsfeit heeft te gelden het geheel aan feitelijke informatie die een partij aanvoert ter onderbouwing van het intreden van het door die partij ingeroepen rechtsgevolg, welke feitelijke informatie dus volgens die partij voldoet aan de kwalificatie die de toepasselijke rechtsregel als voorwaarde stelt voor het intreden van dat rechtsgevolg. Uiteraard moet de rechter uiteindelijk beslissen of dit laatste rechtens juist is. Maar totdat de rechter heeft beslist over het door die partij ingeroepen rechtsgevolg en daarmee over welke feitelijke informatie daarvoor al of niet voldoende was, dus wat de rechtsfeiten in casu behoren te zijn en in hoeverre de gestelde feitelijke informatie al of niet daartoe behoort, moet in de procedure dat geheel aan feitelijke informatie als rechtsfeit worden behandeld. De Groot ${ }^{32}$ spreekt meen ik daarom in het voetspoor van Tjong Tjin Tai ${ }^{33}$ en De Bock ${ }^{34}$ van een rechtsfeit 'wanneer een partij een normatief standpunt inneemt ten aanzien van het feit'. Van het rechtsfeit onderscheiden zij het blote feit, de beschrijving of uitspraak die enkel de werkelijkheid

3I De Groot 20I2/4.5.I lijkt deze feiten ook te beschouwen als rechtsfeiten, maar de enige normatieve lading die de verweerder geeft, is dat de vordering moet worden afgewezen. Dat rechtvaardigt m.i. niet de kwalificatie rechtsfeiten.

32 De Groot 20I2/4.I.2.

33 Tjong Tjin Tai 2002, p. 32.

34 De Bock 20II/3.8. 
weergeeft, zonder dat daaraan een normatieve lading wordt gegeven. 35 Uiteraard zijn dergelijke feiten geen rechtsfeiten als zij niet zijn gesteld met het oog op een (onder meer) aan dat feit verbonden rechtsgevolg en zij hebben evenmin relevantie als zij door de wederpartij niet zijn gesteld ter bestrijding van de waarheid van de voor dat rechtsgevolg gestelde rechtsfeiten of ter verhindering van het intreden van dat rechtsgevolg.

Voor ons onderwerp ligt hier echter wel een behoorlijke voetangel, omdat blote feiten wel in het dossier kunnen voorkomen en de mogelijkheid zich kan voordoen dat de rechter van oordeel is dat zij wèl relevant zijn voor het ingeroepen rechtsgevolg of ter bestrijding daarvan. Dan gaan voor de rechter de seinen op oranje: hij nadert de grenzen van de rechtsstrijd. Maar voor het overige worden 'blote feiten' uiteraard om de haverklap in het kader van rechtsfeiten gesteld, met dien verstande dat zij dan binnen de context van het ingeroepen rechtsgevolg een rol spelen, dus behoren tot het complex van alle feitelijke informatie die door een partij wordt aangevoerd als door die partij noodzakelijk geachte voorwaarde voor het intreden van het door haar ingeroepen rechtsgevolg. De blote feiten maken in dat geval dan ook een essentieel onderdeel uit van het rechtsfeit, reden waarom naar mijn mening het begrip rechtsfeit een ruime lading heeft. Het feit: 'De auto van de verweerder reed ter plaatse van het ongeval met een gemeten snelheid van I30 km per uur', is een bloot feit. Nog een bloot feit: 'Ten tijde van het ongeval was het wegdek door hevige regen zeer nat'. Een bloot feitelijke uitspraak, maar al met een impliciete normatieve lading. $\mathrm{Nu}$ wordt daaraan toegevoegd: 'Ten tijde van het ongeval gold ter plaatse een maximumsnelheid van roo km per uur'. Ook dat is een bloot feit, maar met een sterkere impliciete normatieve lading, omdat daaruit blijkt dat de auto van de verweerder in elk geval harder reed dan ter plaatse was toegestaan. De expliciete normatieve conclusie van de eiser volgt dan ook: 'Dus reed verweerder ten tijde van het ongeval niet alleen harder dan was toegestaan maar ook nog met een snelheid die gegeven het zeer natte wegdek onverantwoord hoog was.' Dat vormt dan de onderbouwing van het rechtsfeit dat verweerder (ervan uitgaande dat hij de bestuurder was) een onrechtmatige daad heeft gepleegd die hem kan worden toegerekend, met als rechtsgevolg dat hij de schade van eiser die het gevolg is van het ongeval moet vergoeden.

Bij het spreken over rechtsfeiten in verband met de bevoegdheden van rechter en partijen op het feitelijke vlak moet dus worden onderscheiden tussen de situatie in het proces waarin nog niet vaststaat welke feiten uiteindelijk de beslissende rechtsfeiten zullen blijken te zijn en de situatie dat de rechter daarover heeft beslist. Zolang zich de eerste situatie voordoet, geldt (a) dat de rechter de processuele rechten van partijen heeft te respecteren, maar tegelijkertijd (b) dat het de rechter is die uiteindelijk een uitspraak moet doen die zijns inziens rechtens de juiste is. Enerzijds betekent dit laatste mijns inziens noodzakelijkerwijze dat de rechter altijd opheldering mag vragen van partijen over hun standpunt ten aanzien van een uit het debat blijkend feit waarop partijen zich niet hebben beroepen maar dat volgens de rechter mogelijk wel (mede) beslissend is. Anderzijds zal de rechter hierbij de waarborgen van een eerlijk proces hebben te eerbiedigen, zodat op dit punt het debat volwaardig is aangevuld. In $\$ 3.3$ komen wij hierop terug.

Men spreekt ook wel van ‘concrete feiten'; Tjong Tjin Tai 2002 passim. 
Ten slotte nog een ander aspect dat in het oog kan worden gehouden in verband met ons onderwerp. In de processuele context zijn rechtsfeiten de feiten waarop in ons systeem het bewijs zich richt. Centraal in de bewijslevering staat de beslissing van de zaak, de bewijslevering is gericht op feiten die tot de beslissing van de zaak kunnen leiden, zoals art. I66 lid I Rv het uitdrukt. ${ }^{36}$ Het is van belang dit te onderstrepen, omdat meer dan eens de problemen rond de kwalificatie van een feit als rechtsfeit (of juist niet) hun gevolgen hebben op het terrein van het bewijs en de bewijslastverdeling, in de zin van verdeling van het bewijsrisico die beslissend is voor de afloop van het geding. Ook de in art. I50 Rv neergelegde hoofdregel van bewijsrisicoverdeling stelt de rechtsgevolgen voorop: 'De partij die zich beroept op rechtsgevolgen van door haar gestelde feiten of rechten, draagt de bewijslast van die feiten of rechten.' Het artikel koppelt de bewijslast aan het inroepen van rechtsgevolgen van gestelde feiten en stelt meteen ook buiten twijfel dat bewijslast - in de zin van bewijsrisico - het bewijs van de gestelde rechtsfeiten betreft. Het is dus niet zo dat reeds het stellen van feiten tot bewijslast leidt (daarom is misleidend de gebruikelijke uitdrukking 'wie stelt moet bewijzen'). Dat was ook nooit zo; ook het hierboven al genoemde 'moederartikel', art. I3I5 Cc, gaat van rechtsfeiten uit. Daarom draagt de verweerder die enkel feiten stelt ter betwisting van de door de eiser gestelde rechtsfeiten, geen bewijslast volgens art. I5O Rv, omdat wat hij stelt geen rechtsfeiten zijn, zoals we zojuist zagen. Pas als de door eiser gestelde rechtsfeiten vaststaan en tegenbewijs nog openstaat, behoeft de verweerder dat tegenbewijs te leveren door het bewijs van de door hem gestelde feiten. Dit - aan het Duitse recht ontleende - systeem noodzaakt zowel partijen als de rechter om op grond van de ingeroepen rechtsgevolgen na te gaan welke de rechtsregel is die de ingeroepen rechtsgevolgen aan de gestelde feiten verbindt en of de gestelde feiten kunnen worden gekwalificeerd als de rechtsfeiten waaraan die rechtsregel het ingeroepen rechtsgevolg verbindt.

\section{Vier opdrachten aan de rechter: art. 23, art. 24 en art. $25 \mathrm{Rv}$}

\section{I Inleiding}

In het vorige hoofdstuk is aandacht besteed aan de wijze waarop feiten en recht op elkaar inwerken in het proces. In de dynamiek van het proces vindt de afbakening plaats van de bevoegdheden van de partijen en die van de rechter om te bepalen waarover het proces gaat, binnen welk feitelijk en juridisch kader de rechter heeft te beslissen. Het begrip rechtsfeit stond daarin centraal omdat het via het rechtsgevolg de verbinding vormt tussen feiten en het recht (de rechtsregel) waardoor de feiten relevantie krijgen voor de in het proces ingeroepen rechtstoepassing. In dit hoofdstuk vindt uitwerking plaats aan de hand van de drie artikelen in het Wetboek

36 Art. I66 Rv betreft de toegang tot bewijslevering door het laten horen van getuigen: 'Indien bewijs door getuigen bij de wet is toegelaten, beveelt de rechter een getuigenverhoor zo vaak een van de partijen het verzoekt en de door haar te bewijzen aangeboden feiten betwist zijn en tot de beslissing van de zaak kunnen leiden. Hij kan dit ook ambtshalve doen.' 
van Burgerlijke Rechtsvordering die sinds de belangrijke vernieuwingsoperatie van 2002 de materie bestrijken ${ }^{37}$ :

- art. $23 \mathrm{Rv}$ 'De rechter beslist over al hetgeen partijen hebben gevorderd of verzocht';

- art. $24 \mathrm{Rv}$ 'De rechter onderzoekt en beslist de zaak op de grondslag van hetgeen partijen aan hun vordering, verzoek of verweer ten gronde hebben gelegd, tenzij uit de wet anders voortuloeit';

- art. $25 \mathrm{Rv}$ 'De rechter vult ambtshalve de rechtsgronden aan'.

Deze bepalingen behoren tot de algemene voorschriften voor procedures (Afdeling 3 van Boek I, titel I Rv) omdat zij gelden voor alle soorten procedures - dagvaardingsprocedure en verzoekschriftprocedure - en in alle instanties.

Zij zijn, evenals andere bepalingen in die afdeling, ${ }^{3^{8}}$ de uitdrukking van fundamentele beginselen van het civiele procesrecht en geven de rechter stringent ogende opdrachten ten aanzien van de grondslagen en inhoud van zijn beslissing. Meestal wordt bij de bespreking van deze wetsartikelen meteen overgeschakeld naar de grondslagen van vordering en verweer en dat is begrijpelijk omdat zij de grondslag van de beslissing daaraan koppelen. Maar het is van belang te onderstrepen dat deze bepalingen de rechter aanspreken op zijn verantwoordelijkheid voor een deugdelijke beslissing waarin recht wordt gedaan aan het geschil zoals dat in vordering en verweer aan hem is gepresenteerd. Als het gaat om de rechtsstrijd en de manier waarop de rechter daarmee omgaat, is die verantwoordelijkheid van de rechter de kern. Partijen debatteren met elkaar vanuit hun eigen belangen, het winnen van de zaak staat daarbij uiteraard voorop. Dat debat geeft de rechter speelruimte omdat hij uiteindelijk beslist en daartoe de standpunten van partijen zal moeten interpreteren, wegen en beoordelen.

Bij dit uitgangspunt kunnen, naar mijn mening, die standpunten per definitie geen dictaat aan de rechter zijn maar moeten zij ook van de kant van de rechter ter discussie gesteld kunnen worden. Dat moet niet pas gebeuren in het vonnis maar juist voordat het vonnis wordt geveld. Partijen en de hogere rechter moeten de rechter (en hij moet zichzelf) die ruimte gunnen. Een systeem dat de rechter in een fijnmazig en ondoorzichtig web opsluit - en daar lijkt het soms op in de onderhavige materie - waarborgt allesbehalve een goede beslissing van het geschil. Het is daarom goed als de drie bepalingen die in dit hoofdstuk worden besproken zo worden uitgelegd en toegepast dat de rechter voldoende ruimte wordt gelaten en dat de opdrachten niet ontaarden in een keurslijf van voorschriften maar worden gezien als een kader dat ruim genoeg is om de rechter in een behoorlijk proces dat eerlijk verloopt en partijen tot het laatst de gelegenheid geeft hun invloed op de rechterlijke oordeelsvorming uit te oefenen, in staat te stellen recht te doen in het geschil, zoals hij dat met het oog op de belangen van de partijen en van een behoorlijke rechtspraak in het algemeen verantwoord vindt. De artikelen zijn de uitdrukking

37 Nieuw waren toen de artikelen $23 \mathrm{Rv}$ en $24 \mathrm{Rv}$; art. $25 \mathrm{Rv}$ stond al in de wet als art. $48 \mathrm{Rv}$.

38 Ik noem art. I9 (hoor en wederhoor, zie boven § I.2), art. 20 (waken tegen onredelijke vertraging van het proces), art. 2I (waarheids- en volledigheidsplicht van partijen t.a.v. het aanvoeren van de voor de beslissing van belang zijnde feiten), art. 22 (inlichtingen- en exhibitieplicht van partijen op bevel van de rechter), art. 26 (verbod van rechtsweigering door de rechter), art. 27 en 28 (openbaarheid van behandeling en uitspraak) en art. 30 (motiveringsplicht van de rechter in zijn uitspraken). 
van beginselen van burgerlijk procesrecht en die functie moeten ze in het proces ook kunnen vervullen doordat bij hun uitleg en toepassing rekening wordt gehouden met de dynamiek van de interactie tussen partijen onderling en tussen en de rechter. Het proces is ervoor om het onderzoek te doen dat nodig is voor de beslissing en om zo nodig en zo mogelijk het kader waarbinnen dat moet gebeuren, te wijzigen. Daartoe biedt het procesrecht trouwens vanouds ook de middelen door de mogelijkheid van wijziging van (de gronden van) de eis door de eiser of van het verweer door de verweerder. ${ }^{39}$

\subsection{Het petitum - art. $23 \mathrm{rv}$ 'de rechter beslist over al hetgeen partijen hebben gevorderd of verzocht'}

Art. $23 \mathrm{Rv}$ betreft het petitum: wat gevorderd of - in de verzoekschriftprocedure verzocht wordt. Men kan met de Belgische terminologie ook zeggen: het voorwerp van de vordering of eis. Het artikel verplicht de rechter om ten aanzien van het gehele petitum uitspraak te doen.

Voor de uitleg van wat wordt gevorderd dient de rechter ook zo nodig te letten op de gronden van de eis en van het verweer, met name hoe de verweerder de vordering heeft opgevat en heeft mogen opvatten. In dit verband is ook een thema of de rechter, gelet op de vordering, minder mag toewijzen dan gevorderd. De Hoge $\mathrm{Raad}^{40}$ heeft ten aanzien van dat thema beslist dat als de eiser een bedrag vordert uit hoofde van geldlening en gedaagde stelt dat wel een geldlening tot stand is gekomen maar tegen een lager bedrag dan door eiser gesteld, de rechter ervan moet uitgaan dat in wat op grondslag van de overeenkomst is gevorderd een vordering tot een lager bedrag besloten ligt voorzover ook die vordering redelijkerwijs op die grondslag kan worden gebaseerd. Een voorbeeld daarvan geeft een recente uitspraak van de Hoge Raad.

Een door ziekte arbeidsongeschikte werknemer vordert van zijn werkgever doorbetaling van zijn loon op grond van de volgens de werknemer toepasselijke collectieve arbeidsovereenkomst (cao). Het hof wijst die vordering af omdat de werknemer niet heeft bewezen dat deze cao van toepassing is. De werknemer had niet met zoveel woorden subsidiair het wettelijke percentage van 70\% van het loon gevorderd (art.7:629 lid I BW). In cassatie wordt geklaagd dat het hof de vordering niet geheel had mogen afwijzen zonder te onderzoeken of zij op grond van die wetsbepaling gedeeltelijk toewijsbaar was, aangezien de arbeidsongeschiktheid wegens ziekte vaststond. De Hoge Raad vernietigt het arrest van het hof. Hij legt de stellingen van de werknemer, bezien in samenhang met het petitum (waarin doorbetaling van het hele bruto loon werd gevorderd) zo uit, dat zij geen andere uitleg toelaten dan dat de werknemer veroordeling verlangt tot betaling van loon primair voor 100\%, met toepassing van cao-bepalingen, en subsidiair gedeeltelijk op de voet van art. 7:629 lid I BW. Dan wordt overwogen: 'Nadat het hof had geoordeeld dat aan [eiser] geen beroep toekwam op de CAO Metaalbewerking, is het niet ingegaan op de vraag of de vordering gedeeltelijk toewijsbaar was. Als het hof dit niet heeft gedaan omdat het van oordeel was dat art. 7:629 lid I BW daarvoor geen grondslag kon bieden, is het van een onjuiste rechtsopvatting uitgegaan. Het hof had

39 De rechter kan dat uiteraard niet, zie voor het petitum art. $23 \mathrm{Rv}$, hierna $\$ 3.2$ en voor de grondslagen art. $24 \mathrm{Rv}$, hierna $\$ 3.3$.

40 HR 5 januari 1996 , NJ I $996 / 449$ (m.nt. H.E. Ras). 
immers reeds vastgesteld dat tussen partijen sprake was van een arbeidsovereenkomst voor onbepaalde tijd, en de arbeidsongeschiktheid van [eiser] wegens ziekte was niet in geschil. Als het hof op andere gronden van oordeel was dat voor gedeeltelijke toewijzing van de vordering onvoldoende grond bestond, is zijn oordeel in ieder geval onvoldoende gemotiveerd. ${ }^{41}$

In het kader van dit preadvies kan de vraag wat er moet gebeuren als de rechter nalaat te beslissen op een of meer onderdelen van de vordering, blijven rusten. Wel verdient opmerking dat art. $32 \mathrm{Rv}^{42}$ het mogelijk maakt de partij die dat treft de rechter kan verzoeken zijn uitspraak aan te vullen. De rechter mag dat echter niet ambtshalve doen, de wetstekst 'op verzoek van een partij' is dwingend. Dat heeft niet zozeer van doen met de partijautonomie als wel met de rechtszekerheid met betrekking tot de uitspraak die te veel in het gedrang zou komen als de rechter elk willekeurig moment zelf zijn uitspraak zou kunnen aanvullen. ${ }^{43}$

Het is de rechter in het algemeen niet toegestaan meer of anders toe te wijzen dan is gevorderd (non ultra of extra petita). ${ }^{44}$ De regel is een uitdrukking van de exclusieve bevoegdheid van de eiser (of de verweerder die als eiser optreedt t.a.v. een tegenvordering) om te bepalen wat de rechter dient toe te wijzen.

Door Hartkamp 45 is de vraag opgeworpen of de rechter een in het proces aan de orde zijnde rechtshandeling die strijdig blijkt te zijn met de goede zeden of de openbare orde en volgens art. 3:40 BW absoluut nietig is, ambtshalve, dus zonder dat een van de partijen in het geding dat heeft gevorderd, nietig zou mogen verklaren. Omdat de kwestie samenhangt met het aanvullen van (Europese) rechtsgronden, zal ik daarop verder ingaan in $\$ 3 \cdot 4 \cdot 7 \cdot 2$.

\subsection{De grondslag van de beslissing - art. $24 \mathrm{Rv}$ 'de rechter onderzoekt en beslist de zaak op de grondslag van hetgeen partijen aan hun vordering, verzoek of verweer ten gronde hebben gelegd, tenzij uit de wet anders voortvloeit'}

\subsubsection{De rechtsstrijd wordt gevormd door partijen}

Art. $24 \mathrm{Rv}$ vormt de basis van de beslissing van de rechter en zijn onderzoek van de zaak. Die basis is wat de partijen in de procedure aanvoeren: wat zij aan vordering en verweer te grondslag hebben gelegd.

4I HR I7 oktober 20I4, ECLI:NL:HR:20I4:3000.

42 Art. 32 lid I Rv: 'De rechter vult te allen tijde op verzoek van een partij zijn vonnis, arrest of beschikking aan indien hij heeft verzuimd te beslissen over een onderdeel van het gevorderde of verzochte. De rechter gaat niet tot de aanvulling over dan na partijen in de gelegenheid te hebben gesteld zich daarover uit te laten.'

43 Memorie van Toelichting; Ten Kate \& Wesseling-van Gent 2013, p. 245-246. NB: verbetering van kennelijke fouten in de uitspraak (art. 3I Rv) mag wel ambtshalve.

44 Een belangrijke uitzondering daarop vormt de vaststelling van een dwangsom, art. 6rib Rv, welke ook hoger kan zijn dan gevorderd, BenGH 17 december I992, nr. A 9I/4, NJ 1993/545 (H.J. Snijders).

45 A.S. Hartkamp, Ambtshalve aanvulling van rechtsgronden naar Europees recht en naar Nederlands recht (oratie Nijmegen), Deventer: Kluwer 2007. 
Het artikel koppelt de grondslag van de beslissing van de rechter aan de grondslagen van vordering (in de verzoekschriftprocedure: verzoek) of verweer. Waar in het artikel ook die koppeling wordt gelegd met het onderzoek van de zaak, is dat het onderzoek dat aan de basis van de beslissing ligt, dat in die beslissing heeft doorgewerkt. Een rechter kan tijdens de behandeling van de zaak bij zijn onderzoek de door art. 23 en $24 \mathrm{Rv}$ gestelde grenzen best overschrijden, bijvoorbeeld om een schikking te bereiken of juist om zicht te krijgen op waar die grenzen liggen, wat precies wordt gevorderd of wat het verweer is dat daartegen wordt gevoerd. Het komt geregeld voor dat de rechter met dat doel op de zitting informatie vraagt en krijgt over achtergronden en aspecten die uiteindelijk niet dragend zijn voor de beslissing. Echter ten aanzien van de door de rechter gegeven beslissing bindt art. $24 \mathrm{Rv}$ het onderzoek aan de in dat artikel beschreven grondslag. Dat blijkt uiteindelijk definitief pas uit de beslissing zelf, uit de uitspraak waarin die voorkomt. ${ }^{46}$ Voor de beantwoording van de vraag of de rechter zich aan die grondslag heeft gehouden is namelijk de inhoud van de beslissing de maatstaf, dat wil zeggen uiteindelijk het dictum en de geschilbeslissingen die het dictum dragen ${ }^{47}$ en uiteraard de motivering van die beslissingen. Geen rol spelen daarbij de overwegingen 'ten overvloede' die het dictum niet dragen en evenmin tussenbeslissingen van de rechter met betrekking tot het onderzoek - bijvoorbeeld bewijslevering - die uiteindelijk de beslissing in het dictum van de einduitspraak over het geschil of een onderdeel daarvan niet dragen. Overigens kan het natuurlijk voorkomen dat de rechter in een tussenbeslissing (opgenomen in een tussenuitspraak) de door art. 23 en $24 \mathrm{Rv}$ gestelde grenzen overschrijdt. Denk bijvoorbeeld aan een bewijsopdracht die getuigt van miskenning van de grenzen van de rechtsstrijd. Dat zou aanleiding kunnen zijn, na verkregen verlof van diezelfde rechter, $4^{8}$ om van die beslissing in appel te gaan. Dan zal de appelrechter over een eventuele overschrijding van de grenzen van de rechtsstrijd moeten beslissen (of de cassatierechter als het gaat om tussenuitspraken van de appelrechter).

Meestal wordt art. $24 \mathrm{Rv}$ aan de orde gesteld in verband met de negatieve opdracht aan de rechter om niet zelf feiten te gaan sprokkelen (daarover meer hierna). Maar in de eerste plaats is sprake van een positieve opdracht: de rechter moet de grondslagen van vordering en verweer serieus nemen bij het vormen van zijn oordeel. ${ }^{49}$ Partijen verzamelen en presenteren de feitelijke en juridische componenten van de beslissing op de vordering; zij bepalen in hun wederzijdse standpunten het aan de rechter voorliggende 'geschil'. Partijen vormen het '(partij)debat' of 'de rechtsstrijd'. Dat zijn termen die in dit verband hetzelfde uitdrukken en afwisselend in de rechtspraak worden gebruikt, met name in combinatie met 'de grenzen van', omdat art. $24 \mathrm{Rv}$ ook de maatstaf geeft voor het bepalen van de grenzen (de omvang) van het door de rechter te beslissen geschil.

46 Definitief, omdat de rechter tijdens een zitting ook wel al iets kan zeggen - als partijen dat willen over wat hij van de zaak vindt en wat de beslissing zou zijn.

47 Vgl. de beslissingen waaraan het gezag van gewijsde toekomt waarop art. 236 lid I Rv ziet: 'Beslissingen die de rechtsbetrekking in geschil betreffen en zijn vervat in een in kracht van gewijsde gegaan vonnis, hebben in een ander geding tussen dezelfde partijen bindende kracht.'

48 Tussentijds hoger beroep of cassatieberoep van tussenuitspraken vereist verlof van de rechter die de tussenuitspraak heeft gedaan, art. 337 lid 2 en art. 358 lid 4 Rv.

Dat was niet gebeurd in HR I2 mei 2006, ECLI:NL:HR:2006:AV8720. 
In de rechtspraak en literatuur pleegt men de grondslagen waarop beide partijen procederen (wat zij 'aan hun vordering, verzoek of verweer ten gronde hebben gelegd') die art. $24 \mathrm{Rv}$ op het oog heeft, te benoemen als 'feitelijke grondslagen'. Die terminologie gaat terug op de situatie van de wet vóór wijziging in 2002, toen wij alleen het oude art. $48 \mathrm{Rv}$ hadden, het equivalent van het huidige art. $25 \mathrm{Rv} \cdot .^{\circ} \mathrm{Uit}$ de in deze artikelen neergelegde verplichting van de rechter tot ambtshalve aanvulling van rechtsgronden leidde men (en leidt men nog steeds) a contrario af dat het de rechter niet is toegestaan de feitelijke gronden aan te vullen. Sinds de invoering van art. $24 \mathrm{Rv}$ wordt dit verbod positief ingelezen in art. 24 Rv. ${ }^{\mathrm{I}}$

Maar afgezien daarvan, inderdaad zijn het feiten en vooral rechtsfeiten, zoals hierboven in $\$ \mathbf{2 . 2}$ genoemd, die partijen aan hun vordering respectievelijk verweer ten grondslag leggen. Zowel de eiser als de verweerder presenteren hun feitelijk betoog (hun 'verhaal') waaruit zij, als het goed is, vervolgens de relevante juridische conclusies trekken met het oog op de beslissing van de rechter, die immers op rechtstoepassing berust. Vanwege dit laatste plegen de grondslagen waarop art. 24 $\mathrm{Rv}$ doelt mede juridisch van aard te zijn, de rechtsgronden, met name voor de eiser, die zijn vordering zal baseren op de rechtsgevolgen van de door hem gestelde feiten. Advocaten zullen zeker de rechtsfeiten en de rechtsgronden als zodanig presenteren. Maar waar de juridische bijstand ontbreekt $\mathrm{t}^{52}$ zal het wellicht blijven bij feiten, blote feiten en feitelijke mededelingen met een in algemeen spraakgebruik verpakt normatief karakter die door de partijen niet zijn vervat in de juridisch-technisch correcte terminologie maar wel juridische relevantie hebben (klant: 'Ik hoef die gordijnen die ik heb ontvangen niet te betalen, want ze zijn niet wat ik heb afgesproken in de winkel'; de leverancier: 'Ik heb van de klant nooit gehoord dat er iets mankeerde aan de door ons geleverde gordijnen'). Weliswaar kan een verweerder zich in voorkomend geval beperken tot het ontkennen van de waarheid van die door de eiser gestelde feiten met het doel dat de rechter niet door eiser gestelde rechtsgevolgen van de door hem gestelde feiten zal erkennen (leverancier: 'De geleverde gordijnen zijn van de stof en het dessin die de klant bij in de winkel heeft afgesproken en daarom heb ik recht op betaling'; klant: 'Dit zijn niet de gordijnen die ik heb afgesproken in de winkel'). Maar ook de verwerende partij zal meestal rechtsgronden aanvoeren om het door eiser ingeroepen rechtsgevolg te bestrijden. Zij kan zich beroepen op rechtsregels die meebrengen dat dit rechtsgevolg niet intreedt (klant: 'Ik heb dadelijk na ontvangst opgebeld en gezegd aan de mevrouw die ik sprak dat de gordijnen niet klopten met wat ik had afgesproken en die mevrouw zou dat doorgeven', wat juridisch geduid kan worden als voldoen aan de klachtplicht van de koper in art. 7:23 BW). Denk ook bijvoorbeeld aan het beroep op de derogerende werking van

50 Art. 48 (oud) Rv luidde: 'De regters moeten bij hunne beraadslagingen van ambtswege de regtsgronden aan vullen welke niet door de partijen mogten zijn aangevoerd.' Voor het toenmalige art. $48 \mathrm{Rv}$ zie men het in noot 2 genoemde preadvies van Sterk en de in noot I genoemde dissertatie van Crommelin. Lange tijd is de dissertatie van J.J. Vriesendorp, Ambtshalve aanvullen van rechtsgronden in het burgerlijk geding, Leiden I970, de Fundgrube voor de rechtspraak op art. $48 \mathrm{Rv}$ geweest. Later heeft Vriesendorp daarvan een verkorte en aangevulde uitgave laten verschijnen: Ambtshalve aanvullen van rechtsgronden, Serie Studiepockets privaatrecht, nr. 23, Zwolle: Tjeenk Willink I98I.

5I Zie voor een en ander Tjong Tjin Tai 2002, p. 29-30.

52 Dat kan steeds meer voorkomen nu de competentiegrens voor zaken waarin geen verplichte procesvertegenwoordiging door een advocaat geldt (de kantonzaken) op 25.000 ligt. 
de redelijkheid en billijkheid, art. 6:248 lid 2 BW: in de gegeven omstandigheden is het intreden van de door eiser op grond van een contractuele regel naar maatstaven van redelijkheid en billijkheid onaanvaardbaar. De verweerder kan zich ook beroepen op een interpretatie van de door eiser ingeroepen rechtsregel die meebrengt dat deze de door eiser ingeroepen rechtsgevolgen juist niet verbindt aan de door eiser gestelde rechtsfeiten.

Kortom, het behoeft geen betoog dat de grondslagen waarover art. 24 Rv spreekt in verreweg de meeste gevallen zowel feitelijk als juridisch van aard zijn: feitelijke gronden en rechtsgronden. Die twee zijn veelal niet te scheiden als gevolg van de hierboven in hoofdstuk 2 beschreven inwerking van feiten en recht op elkaar. We kunnen daarom beter aansluiten bij de wet en simpelweg spreken van grondslagen van vordering/verzoek en verweer. Die grondslagen bevatten feitelijke elementen ('blote feiten') ${ }^{53}$ en juridische elementen (rechtsregels, rechten, kwalificaties, rechtsgevolgen). ${ }^{54}$ Die grondslagen vormen naar mijn mening in hun geheel (feitelijk en juridisch) de rechtsstrijd en art. $24 \mathrm{Rv}$ bindt de rechter in principe aan de inhoud en omvang daarvan.

Bij dit alles is het van belang om in het oog te houden dat het aan de rechter is om te interpreteren wat ieder van hen precies bedoelt. De rol van de rechter wordt niet enkel bepaald door wat 'partijen' willen en beogen maar mede (en vooral) door de tegenstelling tussen de partijen en de ruimte die daardoor ontstaat voor een zelfstandig optreden van de rechter bij het vaststellen van de omvang van de rechtsstrijd. ${ }^{55} \mathrm{De}$ rechtsstrijd is dan ook uiteindelijk wat de rechter ervan in zijn vonnis maakt - herhaald in appel en zelfs in cassatie, want de Hoge Raad doet aardig mee als het gaat om cassatieklachten over schending van de rechtsstrijd, zoals wij hierna zullen zien.

De rechter mag overigens bij het vaststellen van de inhoud en omvang van de rechtsstrijd in het licht van het beginsel van hoor en wederhoor partijen niet verrassen door zijn interpretatie van de rechtsstrijd. Dan handelt hij naar de rechtspraak van de Hoge Raad in strijd met het fundamentele beginsel van procesrecht dat partijen over de wezenlijke elementen die ten grondslag liggen aan de rechterlijke beslissing, voldoende moeten zijn gehoord en niet mogen worden verrast door een beslissing van de rechter waarmee zij, gelet op het verloop van het processuele debat, geen rekening behoefden te houden. ${ }^{56}$ Meestal is dan sprake van een verboden aanvulling van de in art. $24 \mathrm{Rv}$ bedoelde grondslagen van eis of verweer, zodat de rechter daarmee de grenzen van de rechtsstrijd overschrijdt. ${ }^{57}$ De rechter zal in het oog moeten houden dat er grenzen aan zijn interpretatiemogelijkheden zijn en dat bij twijfel de beoogde interpretatie het beste aan partijen kan worden voorgelegd zodat zij daarover hun standpunt kunnen geven.

53 Zie $\$ 2.2$.

54 De Groot 20I2/4.5.I drukt zich in dit verband enigszins anders uit: de feitelijke grondslag kan niet alleen rechtsfeiten omvatten maar kan ook een 'gemengd feitelijk en juridisch karakter hebben'.

55 Vgl. wat hiervoor in $\$$ 3.I is opgemerkt.

56 HR 3I januari 20I4, ECLI:NL:HR:20I4:2I2; HR 2I december 200I, ECLI:NL:HR:200I:AD3997, NJ 2004/34 (m.nt. W.D.H. Asser).

57 Zoals in HR 3I januari 20I4, ECLI:NL:HR:20I4:2I2 het geval was, waarin het hof - mogelijk per vergissing - een feitelijke stelling van de eiser waarmee deze een verweer van de verweerder bestreed, verkeerd had geïnterpreteerd en op basis daarvan ten onrechte de grondslag van de vordering van de eiser had aangevuld. 


\subsubsection{De rechter mag niet treden buiten de rechtsstrijd}

\subsubsection{Inleiding}

Partijen hebben het exclusieve recht om de grenzen van de rechtsstrijd te verleggen. Zelfs als de rechter een partij suggereert de grondslag van haar verweer of vordering te wijzigen, kan de rechter dat niet zelf bewerkstelligen maar alleen de desbetreffende partij. Dat is wat art. $24 \mathrm{Rv}$ (in verbinding met art. $23 \mathrm{Rv}$ ) leert en het blijkt duidelijk uit de rechtspraak van de Hoge Raad..$^{8}$

De vraag in hoeverre art. $25 \mathrm{Rv}$ daarop een uitzondering vormt op grond waarvan de rechter ambtshalve een wijziging kan brengen in een van de grondslagen, niet alleen wat betreft de juridische elementen maar ook de feitelijke, komt eerst in verband met dat artikel aan de orde en zal daarom worden beantwoord in $\S 3.4$. Ik ben het eens met De Groot waar zij betoogt ${ }^{59}$ dat art. $24 \mathrm{Rv}$ de rechter geen bevoegdheid tot aanvulling toekent zodat de vraag in hoeverre de aanvulling van rechtsgronden aanvulling van de feitelijke grondslag zou moeten meebrengen een vraag is die in het kader van art. $25 \mathrm{Rv}$ aan de orde dient te komen. ${ }^{60}$

Daarnaast speelt de vraag in hoeverre de rechter, zonder dat hij aanvulling van rechtsgronden noodzakelijk vindt, feiten aan zijn beslissing ten grondslag mag leggen die niet door een van de partijen deel zijn gemaakt van de in art. 24 Rv bedoelde grondslagen van vordering of verweer. De rechter put dan feiten uit het dossier of uit een andere bron waarop partijen zich niet hebben beroepen. We zullen in dit verband in de volgende paragraaf aandacht besteden aan art. I49 Rv, dat de bronnen benoemt waaruit de rechter mag putten. In $\$ 3 \cdot 3.2 .3$ komen de grenzen van art. $24 \mathrm{Rv}$ aan de orde en in $\$ 3 \cdot 3 \cdot 2.4$ wordt afgerond met een case study ten aanzien van art. $\mathrm{I} 49 \mathrm{Rv}$ en art. $24 \mathrm{Rv}$ in hun onderlinge relatie.

\section{3·3.2.2 De grenzen van art. $\mathrm{I} 49 \mathrm{Rv}$}

Art. I49 Rv luidt:

1. Tenzij uit de wet anders voortvloeit, mag de rechter slechts diefeiten of rechten aan zijn beslissing ten grondslag leggen, die in het geding aan hem ter kennis zijn gekomen of zijn gesteld en die overeenkomstig de voorschriften van deze afdeling zijn komen vast te staan. Feiten of rechten die door de ene partij zijn gesteld en door de wederpartij niet of niet voldoende zijn betwist, moet de rechter als vaststaand beschouwen, behoudens zijn bevoegdheid bewijs te verlangen, zo vaak aanvaarding van de stellingen zou leiden tot een rechtsgevolg dat niet ter vrije bepaling van partijen staat.

2. Feiten of omstandigheden van algemene bekendheid, alsmede algemene ervaringsregels mogen door de rechter aan zijn beslissing ten grondslag worden gelegd, ongeacht of zij zijn gesteld, en behoeven geen bewijs.

58 HR I oktober 2004, NJ 2005/92 (Poort/Stoppels); HR 24 juni 2005, NJ 2006/46 (Dimopoulos/Van Mierlo-Konings); HR I7 februari 2006, NJ 2006/I58; HR 3I maart 2006, NJ 2006/233; HR 7 april 2006, ECLI:NL:HR:2006:AU6935 (X/curator Bakker); HR I4 maart 2008, NJ 2008/466 (J.M.M. Maeijer en H.J. Snijders) (X./mr. Aerta q.q.).

59 De Groot 2012/4.7.2.

6o Zo ook Asser, Groen \& Vranken 2006/5.6. 
Het artikel is het eerste van afdeling I.2.9 Rv, waarin het bewijsrecht wordt geregeld. Wij moeten de bepaling dan ook in de eerste plaats zien als een bewijsrechtelijke, dat wil zeggen dat zij afbakent op welke feiten (en rechten) de bewijsregels in het proces betrekking hebben. In de rechtspraak en de literatuur wordt zij echter ook in verband gebracht met ons onderwerp. Dan is vooral de eerste zin van het eerste lid van belang, evenals de uitzondering daarop in het tweede lid. De tweede zin van het eerste lid betreft vooral het bewijs en legt de rechter de verplichting op om feiten die door de ene partij zijn gesteld en door de andere partij niet, of naar het oordeel van de rechter niet voldoende zijn bestreden, als vaststaand te beschouwen. Die verplichting drukt uit dat de partij die dat feit stelt niet door de rechter gedwongen kan worden het alsnog te bewijzen. Dat is slechts anders indien het door partijen ingeroepen rechtsgevolgen betreft die partijen niet gezamenlijk in het leven kunnen roepen, zoals een huwelijk. De rechter zal ongeacht de omstandigheid dat partijen eendrachtig stellen getrouwd te zijn, bewijs daarvan mogen verlangen als naar zijn oordeel het bestaan van het huwelijk niet voldoende in het proces is gestaafd.

Art. I49 Rv betreft mijns inziens niet zozeer de grenzen van de rechtsstrijd waarop art. 24 Rv betrekking heeft, maar vooral de bronnen waaruit de rechter de feitelijke informatie mag putten die hij aan zijn beslissing ten grondslag legt. Die bronnen worden gevormd door alles wat de partijen in het geding hebben gesteld, zowel in hun in het geding overgelegde processtukken en de door hen overgelegde bewijsstukken als mondeling (op een comparitie, bij gelegenheid van een getuigenverhoor, een deskundigenonderzoek, een bezichtiging ter plaatse, desgevraagd of spontaan). Voorts kunnen het alle andere gegevens zijn die de rechter in het geding op andere wijze ter kennis zijn gekomen, bijvoorbeeld uit de bewijsstukken, uit verklaringen van derden, zoals getuigen en deskundigen, en door zijn eigen waarneming ter zitting dan wel bij bezichtigingen, ook als die waarnemingen niet in een proces-verbaal zijn vastgelegd. Van een zitting (comparitie of mondelinge behandeling, pleitzitting) wordt namelijk in de praktijk lang niet altijd een uitvoerig proces-verbaal opgemaakt; de rechter kan ook in zijn uitspraak van zulke waarnemingen mededeling doen en zijn beslissing daarop baseren. ${ }^{6}$ Hier blijft verder rusten de bewijsrechtelijke eis dat de door de rechter aan zijn beslissing ten grondslag gelegde feitelijke informatie naar de regels van het bewijsrecht is komen vast te staan.

Essentieel is dat deze veelheid van bronnen in het geding aanwezig is. De rechter die zelf op zoek gaat naar feiten - tegenwoordig vaak op internet - mag wat hij heeft gevonden niet zonder meer voor zijn beslissing gebruiken. Dan schendt hij art. I49 Rv en bovendien het beginsel van hoor en wederhoor (art. I9 Rv) omdat hij gegevens gebruikt waarover partijen zich niet hebben kunnen uitlaten. ${ }^{62} \mathrm{Hij}$ zal hoe dan ook

6I Naar vaste rechtspraak van de Hoge Raad is de rechter bij de vaststelling in zijn uitspraak van het ter zitting verhandelde niet aan de inhoud van het proces-verbaal gebonden, zodat een verschil tussen de inhoud van het proces-verbaal en de overweging van de rechter waarop de beslissing steunt, deze laatste niet zonder meer onbegrijpelijk maakt (HR I6 april 2004, NJ 2004/425). Van onbegrijpelijkheid van de uitspraak was wèl sprake in HR 2 maart 20I2, NJ 2012/I57 omdat het hof zijn uitspraak deed stoelen op een voorval ter zitting waarvan het proces-verbaal geen bevestiging inhield, doch veeleer een vermelding bevatte die op het tegendeel daarvan duidde.

62 HR I5 april 20II, ECLI:NL:HR:20II:BP56I2; HR 9 september 20II, ECLI:NL:HR:20II:BRI654. 
eerst die informatie met de partijen moeten delen en hun reactie daarop moeten vragen. Art. I49 Rv staat ook in de weg aan het gebruiken van feitelijke informatie uit in het geding overgelegde stukken uit een andere procedure, als niet voor wederpartij en rechter duidelijk is dat de partij die deze stukken heeft overgelegd die informatie aan haar standpunt ten grondslag heeft gelegd. ${ }^{63}$

In hoeverre de rechter deze feitelijke informatie aan zijn beslissing ten grondslag mag leggen, wordt bepaald door de grenzen van de rechtsstrijd (art. $24 \mathrm{Rv}$ ) en door de manier waarop de rechter die informatie gebruikt. De rechter mag binnen de rechtsstrijd alle mogelijke in het geding gestelde of gebleken feitelijke informatie gebruiken voor zijn beoordeling van de betwiste grondslagen van vordering of verweer. ${ }^{64}$ Zoals door de Hoge Raad geformuleerd: het staat de rechter vrij, binnen de grenzen van de rechtsstrijd, alle behoorlijk te zijner kennis gebrachte en ten processe gebleken feiten en omstandigheden in zijn beoordeling van het hem voorgelegde punt van geschil te betrekken. Hij heeft de vrijheid aan zulke feiten zijn eigen conclusies te verbinden. Dat geldt ook voor feiten en omstandigheden waarop partijen zich niet met zoveel woorden hebben beroepen. ${ }^{65}$

De rechter mag met andere woorden de rechtsfeiten die partijen als grondslag voor vordering en verweer hebben gesteld 'staven' aan die informatie, zoals de wetgever het destijds uitdrukte. Daaronder moet worden verstaan dat de rechter uit allerlei feitelijke informatie die in het geding ter kennis is gekomen de juistheid of onjuistheid van een door een partij als grondslag gesteld rechtsfeit mag afleiden. Uit die informatie mag de rechter de conclusies trekken omtrent dat rechtsfeit die hij nodig vindt, niet alleen op het punt van de juistheid (waarheid) van het feit (dus op het punt van het bewijs). Hij mag dat ook ten aanzien van de rechtsgevolgen die de betrokken partij aan dat rechtsfeit verbindt. Maar daarbij moet hij dus binnen de rechtsstrijd blijven, dat wil zeggen zich beperken tot een beoordeling van het rechtsfeit dat als grondslag was gesteld. Hoever de rechter kan gaan is dan ook een kwestie van interpretatie van de inhoud en reikwijdte van de grondslag en van wat behoort tot het rechtsfeit dat daarvan deel uitmaakt en ter beoordeling staat. Hetzelfde geldt voor een feitelijk verweer. De rechter mag de feitelijke grondslag daarvan staven aan feitelijke gegevens die hij in het dossier vindt, ook als de verweerder zich daarop niet in het bijzonder heeft beroepen. Het zal geen betoog behoeven dat het probleem zich extra scherp manifesteert als de rechter feitelijke gegevens gebruikt die hij aantreft in de stukken die zijn overgelegd door de partij ten nadele van wie hij die gegevens vervolgens gebruikt. Is deze partij bijvoorbeeld eiser, dan zal zij aanvoeren dat de wederpartij die gegevens niet ten grondslag heeft gelegd aan haar verweer, zodat de rechter de grenzen van de rechtsstrijd heeft veronachtzaamd. Maar dan wordt eraan voorbijgezien dat bij de beoordeling van, in dit geval, het verweer van de verweerder de rechter heel wel mag letten op feiten die te vinden zijn in de stellingen van eiser of in door hem overgelegde bewijsstukken die het

63 HR I7 oktober 2008, ECLI:NL:HR:2008:BE720I, (Baros/COA) NJ 2009,476 (H.J. Snijders); HR Io augustus 20I2, ECLI:NL:HR:20I2:BW5867.

64 Memorie van toelichting op art. 24 Rv, A.I.M. van Mierlo, m.m.v. F.M. Bart, Parlementaire geschiedenis Herziening van het burgerlijk procesrecht, Deventer: Kluwer 2002, p. I6I.

65 HR I2 december I997, NJ I998/224; HR 24 september 2004, NJ 2004/672; HR I5 september 2006, ECLI:NL:HR:2006:AX538I. 
door de verweerder gevoerde verweer staven. In dat geval legt de rechter aan zijn beslissing niet een niet gevoerd verweer ten grondslag, omdat het feitelijk gegeven het verweer van de verweerder ondersteunt.

\subsubsection{De grenzen van art. $24 \mathrm{Rv}$}

Van het zojuist genoemde geval moet het volgende worden onderscheiden. Het kan zijn dat de rechter een door hemzelf naar voren gehaalde feitelijke of meer juridische grond gebruikt als grondslag voor zijn beslissing (art. $24 \mathrm{Rv}$ ) in die zin dat hij in zijn beslissing rechtsgevolgen (mede) daaraan verbindt die meebrengen dat bijvoorbeeld de vordering wordt afgewezen, terwijl de partij die daarvan profiteert (de verweerder in dit geval) die grond niet (mede) ten grondslag heeft gelegd aan zijn verweer. Deze partij heeft zich niet op die grond beroepen om te betogen dat de vordering niet toewijsbaar is, zij heeft er met andere woorden geen verweermiddel van gemaakt. Maar dat doet de rechter wel en kennelijk omdat hij van oordeel is dat juist deze grond ertoe leidt dat de vordering niet kan slagen. Op die manier laat de rechter zo'n grond onderdeel worden van de grondslag van zijn beslissing hoewel deze geen deel uitmaakt van de grondslag van het verweer. Daarmee handelt hij in strijd met art. $24 \mathrm{Rv}$ omdat dit artikel de grondslag van de beslissing nu eenmaal bindt aan de door partijen aan vordering respectievelijk verweer gegeven grondslagen. De rechter treedt buiten de grenzen van de rechtsstrijd. Het staat de rechter dus niet vrij zijn beslissing te baseren op bijvoorbeeld feitelijke gronden die weliswaar zouden kunnen worden afgeleid uit in het geding gebleken feiten en omstandigheden, maar die door de desbetreffende partij niet aan haar vordering of verweer ten grondslag zijn gelegd, zoals de Hoge Raad het formuleert. ${ }^{66}$ Hetzelfde geldt voor juridische gronden, zoals op niet door partijen ingeroepen rechtsregel gebaseerde kwalificaties van feiten, zoals door de rechter aangenomen gebrekkigheid van het geleverde product waarvan de leverancier betaling vordert en waartegen de afnemer het verweer voert dat het product niet meer bruikbaar was omdat het later dan afgesproken was geleverd. Het kan ook gaan om rechtsgevolgen die zijn verbonden aan de feitelijke grondslagen, bijvoorbeeld de volgens de rechter uit de vaststaande feiten blijkende maar niet door de verweerder aangevoerde nietigheid van de overeenkomst op basis waarvan de eiser nakoming vordert. Door zulke gronden aan zijn beslissing ten grondslag te leggen overschrijdt de rechter niet alleen de grenzen van de rechtsstrijd maar wordt de wederpartij tekortgedaan in haar recht zich daartegen naar behoren te kunnen verdedigen, zoals de Hoge Raad vanaf 2003 eraan toevoegt. ${ }^{67}$ Met deze toevoeging zet de Hoge Raad

66 HR 29 maart I996, NJ I996/42I.

67 HR 26 september 2003, NJ 2004/46o (Regiopolitie/Hovax); HR I oktober 2004, NJ 2005/92 (Poort/ Stoppels); HR 24 juni 2005, NJ 2006/46 (Dimopoulos/Van Mierlo-Konings); HR ro februari 2006, NJ 2006/I54 (Univé/Axa); HR I7 februari 2006, NJ 2006/I58 (Spector/Fotoshop); HR 3I maart 2006, NJ 2006/233(E.ON/Motion Fors); HR 7 april 2006 (X/curator Bakker), ECLI:NL:HR:2006:AU6935; HR 24 november 2006, NJ 2007/539 (m.nt. H.J. Snijders) (Maastricht School of Management/Kostelijk); HR I2 januari 2007, JOL 2007/9; HR I4 maart 2008, NJ 2008/466 (m.nt. J.M.M. Maeijer en H.J. Snijders) (X./mr. Aerts q.q.); HR 25 april 2008 (Houttuin/X), ECLI:NL:HR:2008:BCo375; HR Io augustus $2012(\mathrm{~A} / \mathrm{X}), \mathrm{NJ} 2012 / 485$. 
het verbod van overschrijding van de rechtsstrijd in het teken van schending van het beginsel van hoor en wederhoor. De rechter mag zijn beslissing niet baseren op een grond die geen voorwerp is geweest van het debat. Hiermee verlegt de Hoge Raad het accent in dit soort gevallen van de partijautonomie naar het fundamentele beginsel van hoor en wederhoor. Dat wil overigens niet zeggen dat als de rechter maar hoor en wederhoor toepast ten aanzien van zijn trouvailles, hij altijd gedekt is. De nieuwe grond moet wel door de partij die het aangaat worden overgenomen als grondslag voor haar vordering of verweer en bovendien moet de stand en instantie waarin de procedure zich bevindt deze uitbreiding van de rechtsstrijd toelaten, wat niet altijd het geval behoeft te zijn zoals blijkt uit het hierna in $\$$ 3.4.4.I besproken arrest Spijkers/Ru-Pro. ${ }^{68}$

Een onmiskenbaar voorbeeld van overschrijding van de grenzen van de rechtsstrijd als bedoeld in art. $24 \mathrm{Rv}$ levert HR I4 december 2012, ECLI:NL:HR:20I2:BY224I. Het betreft een zaak waarin een werknemer voorwaardelijk op staande voet was ontslagen. Het hof overwoog dat de door de werkgever gestelde dringende reden, die vereist is voor een dergelijk ontslag, niet, zoals art. 7:677 lid I BW eist, onverwijld bij de voorwaardelijke ontslagaanzegging is meegedeeld aan de ontslagen werknemer. Het niet mededelen van de dringende reden is een rechtsfeit, leidt nl. tot nietigheid van het ontslag. Maar omdat de werkneemster zich niet op dat feit had beroepen, mocht het hof dat niet ten grondslag leggen aan zijn beslissing dat het ontslag niet kan worden beschouwd als een ontslag wegens een dringende en onverwijld meegedeelde reden, ook al zou uit de in het geding zijnde feitelijke informatie inderdaad af te leiden zijn dat die redenen niet onverwijld zijn meegedeeld.

Het onderscheid tussen overschrijding van de grenzen van de in art. 24 Rv bedoelde rechtsstrijd en het in de vorige paragraaf genoemde geval van schending van art. I49 Rv is niet altijd zo helder. We zagen daar hoe belangrijk het is dat als het gaat om het toelaatbaar 'staven' van een gestelde feitelijke grondslag (rechtsfeit) aan feiten waarop een partij zich niet (expliciet) heeft beroepen, het rechtsfeit dat gestaafd wordt wel daadwerkelijk is gesteld. Maar de interactie tussen art. I49 Rv en art. $24 \mathrm{Rv}$ blijkt steeds weer subtiel te kunnen zijn. De bepalingen zijn op dit punt niet altijd makkelijk van elkaar te onderscheiden. We zien dan ook dat in uitspraken van de Hoge Raad waarin de kwestie aan de orde is, schending van art. I49 Rv, art. I9 $\mathrm{Rv}$ (of: 'het fundamentele beginsel van hoor en wederhoor') en art. $24 \mathrm{Rv}$ naast elkaar genoemd worden. Het is goed daarbij te bedenken dat die drie bepalingen elk hun eigen functie hebben maar kunnen samenlopen. ${ }^{69}$

\subsubsection{Een case study}

$\mathrm{Na}$ alle theoretische uiteenzettingen in de vorige paragrafen is het nodig de problematiek te illustreren aan de hand van een arrest van de Hoge Raad, waarin hij het onderscheid laat zien tussen art. $24 \mathrm{Rv}$ en art. I49 Rv. ${ }^{\circ}$

68 HR 23 september 20II, NJ 20I3/6 (m.nt. H.J. Snijders).

69 Zie bijvoorbeeld HR 3I maart 2006, NJ 2006/233; HR 7 april 2006, ECLI:NL:HR:2006:AU6935; HR 9 september 20II, ECLI:NL:HR:20II:BRI654; HR Io augustus 20I2, ECLI:NL:HR:2012:BW5867.

70 HR I5 september 2006, ECLI:NL:HR:2006:AX538I; JBPr 2007/4 (m.nt. H.T. Verhaar). 
Een werknemer, een chauffeur die de auto van het werk bij hem thuis had staan en was belast met het woon-/werkvervoer van de country-manager van het bedrijf van de werkgever, vordert van zijn werkgever een vergoeding van overwerk. Hij onderbouwt die vordering met een door hem overgelegde urenadministratie die hij zelf heeft bijgehouden. De werkgever voert het verweer dat de werknemer geen overwerk heeft verricht en dat de door de werknemer geproduceerde urenadministratie aantoonbare onjuistheden bevat, waartoe de werkgever een aantal voorbeelden noemt van uren die volgens hem geen werktijden vertegenwoordigen.

Het hof is van oordeel dat de urenadministratie wel in het proces kan worden gebruikt en een vermoeden van overwerk oplevert, maar het stelt vervolgens n.a.v. het verweer van de werkgever dat de urenadministratie onbetrouwbaar is, vast dat in die administratie uren voorkomen die niet als werktijd kunnen gelden. Op grond daarvan vermindert het hof op basis van wat het heeft vastgesteld het bedrag dat de werkgever wegens overuren alsnog aan de werknemer moet vergoeden.

In cassatie komt de werknemer daartegen op met het betoog dat het hof geen uren in mindering had mogen brengen die de werkgever niet had genoemd in zijn verweer. Het gaat dan met name om de door het hof volgens de werknemer ten onrechte in mindering gebrachte uren besteed aan de ritten tussen de woning van de werknemer en het huisadres van de country-manager (dus woon-/werkvervoer van de werknemer zelf).

De Hoge Raad verwerpt dat standpunt. In de eerste plaats overweegt hij dat het hof, gesteld voor de beoordeling van het verweer van de werkgever dat de urenadministratie onbetrouwbaar was, niet in strijd met art. $24 \mathrm{Rv}$ de feitelijke grondslag van het verweer heeft aangevuld. Daartoe wijst de Hoge Raad op een aantal door de werkgever in het kader van zijn verweer genoemde voorbeelden van uren in de door de werknemer overgelegde administratie die geen werktijd waren. Daaraan doet niet af, zo overweegt de Hoge Raad verder, 'dat [de werkgever] niet met zoveel woorden heeft aangevoerd dat ook de met het woon-/ werkverkeer gemoeide tijd (...), volgens haar niet als overwerk kan worden beschouwd, en dat ook daarom de door [de werknemer] bijgehouden urenregistratie onbetrouwbaar was'.

Vervolgens overweegt de Hoge Raad: 'Ook voorzover het middel de klacht zou inhouden dat het hof in strijd met art. I49 Rv. feiten aan zijn beslissing ten grondslag heeft gelegd die niet ten processe zijn gebleken of gesteld en zijn komen vast te staan, is het ongegrond. Het hof mocht bij de beoordeling van de - door [de werkgever] betwiste - betrouwbaarheid van de door [de werknemer] bijgehouden urenadministratie binnen de grenzen van de rechtsstrijd alle behoorlijk te zijner kennis gebrachte en ten processe gebleken feiten en omstandigheden in zijn beschouwingen betrekken en het had de vrijheid daaraan zijn eigen conclusies te verbinden. Dat heeft het hof gedaan. [De werknemer] heeft in hoger beroep (...) aangevoerd dat zijn werktijden beginnen bij het ophalen van de manager en eindigen na het naar huis brengen van de manager. Het hof heeft geoordeeld (...) dat [de werknemer] in de logboeken van de auto van [de werkgever] niet alleen dagelijks het aantal door hem gereden kilometers en de bestemmingen noteerde maar tevens het tijdstip waarop hij van huis vertrok en dat waarop hij weer thuis arriveerde. Het heeft daaruit de - niet onbegrijpelijke - gevolgtrekking gemaakt dat in de door [de werknemer] bijgehouden urenregistratie ook begrepen is de - naar het hof kennelijk en niet onbegrijpelijk uit de stellingen van [de werknemer] heeft afgeleid: ook volgens [de werknemer] niet als werktijd te beschouwen - tijd die gemoeid was met het reizen van het woonhuis van [eiser] naar het woonhuis van de countrymanager en vice versa.' 
Eerst een korte analyse. De Hoge Raad beschouwt als de feitelijke grondslag van het verweer dat de door de werknemer overgelegde urenadministratie onbetrouwbaar is, niet slechts de uren die de werkgever heeft genoemd om te laten zien waarom de urenadministratie onbetrouwbaar was. Die feitelijke grondslag was volgens dit arrest: 'de urenadministratie is onbetrouwbaar', en dus ruimer. Daarom was het hof, dat heeft onderzocht welke uren in de administratie geen werkuren waren, niet gebonden aan de door de werkgever genoemde voorbeelden ter onderbouwing van zijn verweer. We zien dat veel afhangt van de interpretatie van de feitelijke grondslag van het verweer - in dit geval van interpretatie door de cassatierechter een dubbele: de Hoge Raad interpreteert het arrest van het hof ten aanzien van de door het hof kennelijk aangenomen omvang van de rechtsstrijd - want dat schrijven de aan de cassatierechter opgelegde beperkingen t.a.v. feitelijke oordelen voor. De manier waarop dit gebeurt, is overigens wel eigen aan de werkwijze van de Hoge Raad. In dit geval is duidelijk dat het hof volgens de Hoge Raad het verweer van de werkgever zo heeft mogen opvatten dat het hof de vrijheid had om op basis van de door de werknemer overgelegde urenadministratie zelfstandig de overwerkuren vast te stellen.

$\mathrm{Nu}$ het tegenlicht in de vorm van wijziging van het geval. Stel dat de werkgever zijn verweer tegen de vordering tot vergoeding van overwerk zou hebben beperkt tot betwisting van de omvang van de door de werknemer gevorderde vergoeding. In dat geval spitst de werkgever bovendien de feitelijke grondslag van zijn verweer toe op de stelling dat geen vergoeding was verschuldigd voor de door de werkgever genoemde gevallen waarin de urenadministratie niet tot het werk te rekenen uren vermeldt. In dat geval zou de rechtsstrijd zijn beperkt tot die gevallen en zou het hof niet andere, aan het hof gebleken, feitelijke onjuistheden in de urenadministratie ten grondslag aan zijn beslissing hebben mogen leggen en de vordering navenant hebben mogen verminderen. Dan zou het hof de feitelijke grondslag van het verweer hebben aangevuld en de grenzen van de rechtsstrijd hebben overschreden. Wel is voorstelbaar (en ook wel voor de hand liggend) dat het hof in dat geval met partijen zou hebben besproken dat het nog meer uren was tegengekomen in de urenadministratie die niet als werkuren konden worden beschouwd in het licht van de vaststaande feiten - waaronder het feit dat, zoals de werknemer zelf had gesteld en door de werkgever niet was bestreden, de werktijd pas begon als de werknemer met zijn auto was gearriveerd bij het huis van de country-manager en eindigde als hij deze weer had thuisgebracht. Dan is het de vraag hoe partijen reageren - nog afgezien van de prealabele vraag of de stand van de procedure (met name in hoger beroep) een aanvulling door de werkgever van zijn verweer met de door het hof genoemde uren, nog toeliet. Wij komen op dit aspect terug in $\S 3 \cdot 4$.

Maar dit geval deed zich niet voor want de werkgever bestreed dat er überhaupt sprake was van overwerk en daartoe verweerde hij zich tegen de urenadministratie van de werknemer omdat die onbetrouwbaar was. In dat kader noemde hij een aantal voorbeelden om die onbetrouwbaarheid te staven. Het lag voor de hand dat het hof gelet op dat verweer zich verplicht voelde de urenadministratie geheel tegen het licht te houden. Zou het hof zich hebben beperkt tot de door de werkgever genoemde uren, dan zou het aan het verweer te kort hebben gedaan, en dat zou in strijd zijn geweest met de opdracht van art. $24 \mathrm{Rv}$. 


\subsection{Aanvulling van rechtsgronden - art. $25 \mathrm{Rv}$ 'de rechter vult ambtshalve de rechtsgronden aan'}

\subsubsection{Inleiding}

De rechter moet volgens art. $25 \mathrm{Rv}$ ambtshalve de toepasselijke rechtsregels aanvullen. Ius curia novit. Wij kennen niet het 'actiënrecht' van het Romeinse rechtssysteem. Een eiser behoeft geen actie te benoemen om rechtsingang te verkrijgen. De gedaagde behoeft geen bepaald door hem juridisch benoemd verweer te voeren. Wij kennen alleen nog de namen van zulke acties (actio Pauliana) en verweren (exceptio doli) die wij gebruiken om snel duidelijk te maken waarover we het hebben. Partijen mogen in principe volstaan met de feiten te stellen en de rechtsgevolgen die zij aan die feiten verbinden zonder dat zij de rechtsregel hoeven aan te wijzen die daarvoor de juridische grondslag biedt. Het is aan de rechter om gelet op de feiten en de aard en strekking van de ingeroepen rechtsgevolgen die rechtsregel te identificeren of (denk aan de Hoge Raad in laatste instantie) te formuleren. De rechter vindt het recht.

De rechtsregels die de rechter aanvullend moet toepassen ${ }^{71}$ behoeven niet van dwingend recht te zijn en/of van openbare orde. Het gaat zeer in het algemeen om de toepassing van rechtsregels die de rechter in het gegeven geval toepasselijk acht maar niet door de partij die het aangaat zijn ingeroepen. Bij dit laatste hoeft geen sprake te zijn van het uitdrukkelijk noemen van rechtsregels door de partij; het kan ook blijken uit haar stellingen, bijvoorbeeld uit een bepaalde door haar aan de gestelde feiten gegeven kwalificatie. Er kan ook onduidelijkheid bestaan over welke rechtsregels de partij op het oog heeft. In al die gevallen moet de rechter zelfstandig vaststellen welke rechtsregels op de gestelde feiten van toepassing zijn. en dat betekent dat hij ook zelfstandig moet vaststellen welke rechtsgevolgen die rechtsregels aan die feiten verbinden.

In $\S 3.3 .2$ is aan de orde gekomen dat de rechter op grond van art. $24 \mathrm{Rv}$ de grondslagen die partijen aan hun vordering resp. verweer hebben gegeven heeft te respecteren. Daarop vormt deze bepaling in die zin een uitzondering dat de rechter ingevolge art. $25 \mathrm{Rv}$ de verplichting heeft om binnen de door art. $24 \mathrm{Rv}$ afgepaalde rechtsstrijd de rechtsgronden aan te vullen, wat betekent dat hij zijn beslissing baseert op een niet door partijen aangevoerde rechtsgrond die wel past bij de feitelijke grondslag van vordering of verweer. Het gaat om de vraag of het door de betrokken partij ingeroepen rechtsgevolg van een door haar gesteld rechtsfeit - bijvoorbeeld de verplichting tot schadevergoeding - ook kan worden aangenomen op grond van een andere rechtsregel dan door die partij aangevoerd. De vraag is dus: leiden de gestelde feiten ook met toepassing van een andere rechtsregel tot het door de desbetreffende partij blijkens haar processuele standpunt beoogde rechtsgevolg?

Een van de functies van art. $25 \mathrm{Rv}$ is dan ook te voorkomen dat een partij de dupe wordt van een onjuiste rechtsopvatting als haar vordering of verweer ook gehonoreerd kan worden op een andere rechtsgrond dan door haar gesteld. Maar de aanvulling werkt dan meestal ten nadele van de wederpartij. Dus niet iedereen wordt geholpen en dat levert nogal eens grond op voor cassatieklachten op dit terrein.

7I Onder de verplichting tot aanvuliing valt ook het buitenlandse recht: HR I7 december 20Io, ECLI:NL:HR:20I0:BOI979. 
Een andere belangrijke functie is een meer algemeen maatschappelijke: de handhaving van het recht. Dat geldt met name indien dwingend recht en/of recht van openbare orde moet worden toegepast en partijen zich daarop niet hebben beroepen. Daarop wordt hieronder in $\$ 3.4 .7$ ingegaan.

\subsubsection{De strakke regels voor de procedure in hoger beroep}

Omdat de Hoge Raad meestal te oordelen krijgt over uitspraken van de appelrechter, moet, voordat wij verder gaan, enige aandacht worden besteed aan de regels met betrekking tot de rechtsstrijd in appel. ${ }^{72}$ Die regels laten minder ruimte voor koerswijzigingen gedurende de procedure dan de eerste aanleg.

In appel kent men een dubbele omlijning van de rechtsstrijd, te weten (a) de inhoudelijke van art. $24 \mathrm{Rv}$ - 'de rechtsstrijd van partijen' - en (b) een procedurele. Over (a) hebben wij hierboven gesproken; (b) levert (nog) meer moeilijkheden op. Die omlijning vindt plaats door het grievenstelsel, de devolutieve werking van het hoger beroep en de zogeheten 'twee-conclusieregel' (gebaseerd op art. 347 lid I Rv).

De twee-conclusieregel houdt in dat de appellant een memorie van grieven indient waarin hij zijn bezwaren tegen de uitspraak in eerste aanleg aanvoert (grieven) en de vernietiging vordert van de uitspraak in eerste aanleg (al of niet gedeeltelijk), en dat de geïntimeerde vervolgens een memorie van antwoord indient waarin hij de grieven bestrijdt. Daarmee is procedureel de omvang van het hoger beroep, d.w.z. de inhoudelijke geschilpunten en de vordering in appel waarover de appelrechter heeft te beslissen, vastgelegd. ${ }^{73}$ Bij pleidooi in hoger beroep (als dat wordt gehouden) mogen slechts bij uitzondering nieuwe grieven (waardoor de rechtsstrijd in appel wordt uitgebreid) worden aangevoerd. Daarna is er evenmin nog ruimte voor uitbreiding van de rechtsstrijd tenzij de appelrechter goede redenen heeft die ruimte alsnog te geven. ${ }^{74}$

Het grievenstelsel en de devolutieve werking leveren meer problemen op. Een ultrakorte schets volgt hier. De grieven ${ }^{75}$ en de appelvordering van de appellant alsmede het principe van de devolutieve werking van het appel - in hoeverre de grieven het gebied ontsluiten waarbinnen de appelrechter de zaak opnieuw heeft te beoordelen - bepalen tezamen in hoeverre de rechtsstrijd van partijen in appel weer openligt.

72 Zie hierover onder meer F.B. Bakels, A. Hammerstein \& E.M. Wesseling-van Gent, Mr, C. Assers Handleiding tot de beoefening van het Nederlands Burgerlijk Recht. Procesrecht. 4 Hoger Beroep, Deventer: Kluwer 20I2, hoofdstuk Io - over de ambtshalve aanvulling van rechtsgronden nr. I7I-I77; Snijders \& Wendels 2009/229-257. Voor het naadje van de kous raadpleegt men H.E. Ras/A. Hammerstein, De grenzen van de rechtsstrijd in hoger beroep in burgerlijke zaken, Serie Burgerlijk Proces \& Praktijk, Deventer: Kluwer 20II.

73 Ingeval de geïntimeerde bij memorie van antwoord incidenteel appel instelt, heeft de oorspronkelijke (principaal) appellant, dan incidenteel geïntimeerde, nog een mogelijkheid van schriftelijke reactie op de grieven in het incidenteel appel (memorie van antwoord in het incidenteel appel).

74 Zie de arresten HR 20 juni 2008 (Willemse/NOM), NJ 2009/2I (m.nt. J.M.M. Maeijer en H.J. Snijders) en HR I9 juni 2009 (mr. Wertenbroek q.q./Van den Heuvel), NJ 20Io/I54 (m.nt. H.J. Snijders).

75 Het begrip 'grief' wordt door de Hoge Raad zeer ruim opgevat: grieven zijn alle gronden die de appellant aanvoert ten betoge dat de bestreden uitspraak behoort te worden vernietigd, HR 3 februari 2006, NJ 2006/I20 (Budé/Geju). 
De appelrechter mag niet meer beslissen over een of meer onderdelen van de vordering van de eiser die in eerste aanleg in het dictum van het vonnis zijn toe- of afgewezen en van welke toe- of afwijzing in appel geen vernietiging wordt gevorderd. In zoverre is de uitspraak van de eerste rechter na afloop van de appeltermijn onherroepelijk geworden. Voorzover van die uitspraak wèl appel is ingesteld - wat betekent dat de appellant in het dictum van de appeldagvaarding inzoverre vernietiging van het vonnis in eerste aanleg vordert - mag de appelrechter ten aanzien van geschilpunten die verband houden met het (inzoverre) in appel aan de orde gestelde vonnis alleen die geschilpunten (opnieuw) beoordelen voorzover de grieven van de appellant dat mogelijk maken. Er kan over zulke geschilpunten zijn beslist (bijvoorbeeld de verwerping van een verweer) waartegen geen grief is gericht, in welk geval de appelrechter die geschilpunten niet opnieuw mag beoordelen. Zij vallen buiten het 'door de grieven ontsloten gebied' en blijven daarom buiten het bereik van de appelrechter. Ten aanzien van de geschilpunten die wel binnen dat gebied vallen, geldt ook voor de appelrechter de regel van art. $25 \mathrm{Rv}$ : hij zal de rechtsgronden ambtshalve moeten aanvullen maar mag daarbij de grenzen van de rechtsstrijd van partijen niet overschrijden. Hier heeft de appelrechter overigens wel een ruime marge van interpretatie van de stukken (mede in het licht van hoe de wederpartij de grieven heeft mogen opvatten), wat niet wegneemt dat de Hoge Raad die interpretatie op begrijpelijkheid kan toetsen.

Een uitzondering op deze regel vormen echter geschilpunten waarin recht van openbare orde toepasselijk is. ${ }^{76}$ De appelrechter moet dan zo nodig buiten de grieven om dat recht toepassen op reeds besliste geschilpunten. Als gezegd: het gaat hier om geschilpunten die buiten het door de grieven ontsloten gebied vallen maar die wèl betrekking hebben op de rechtsvordering van eiser of een gedeelte daarvan welke ter beslissing aan de appelrechter is voorgelegd door de vordering van de appellant tot vernietiging van de uitspraak van de rechtbank. De openbare orde doorbreekt deze regel niet: (het gedeelte van) de vordering waarover onherroepelijk in eerste aanleg in het dictum van de uitspraak van de rechtbank is beslist maar waarvan geen hoger beroep is ingesteld, blijft ook voor de openbare orde gesloten gebied. ${ }^{77}$

Dit strakke en soms nogal moeilijk te hanteren systeem is enerzijds alleszins gerechtvaardigd. In appel mag immers van de partijen worden verwacht dat de rechtsstrijd door hen - 'wijzer' geworden door het proces en de uitkomst van de eerste aanleg - voldoende doeltreffend is omlijnd door de grondslagen van vordering en verweer. Uitbreiding of wijziging van de grondslagen van de rechtsstrijd in een laat stadium is dan meestal een gepasseerd station, afgezien van tijdens de appelprocedure zich voordoende nova die aanpassing van de rechtsstrijd zouden vergen. Maar anderzijds het kan ook zo zijn dat de appelrechter ziet dat de in appel voor hem geldende grenzen van de rechtsstrijd een niet goed passend keurslijf vormen voor het doen van een uitspraak die naar zijn oordeel de juiste zou zijn. Dan zal de

76 Daarover meer in $\$ 3 \cdot 4.8$.

77 Aldus de zogenoemde 'enge' leer, die door de Hoge Raad en de meeste schrijvers wordt gehuldigd. Zo moet ook worden begrepen overweging 3.6.3 van HRI3 september 2013, ECLI:NL:HR:2013:69I, NJ 2014/274 (m.nt. H.B. Krans) (Heesakkers/Voets), dat hierna in $\$ 3.4 .8 .3$ aan de orde komt. 
appelrechter aanpassing van de rechtsstrijd moeten kunnen toelaten, als een goede procesorde zich daartegen niet verzet. Dit laatste zal zich niet voordoen als alleen langs die weg kan worden gekomen tot een rechtens juiste beslissing. In $\S 3.4 .5$ zullen we vier voorbeelden zien van een dergelijke (al of niet toelaatbare) aanpassing op suggestie van de appelrechter.

\subsubsection{Het aanvullen van rechtsgronden}

Wat aanvullen van rechtsgronden inhoudt, komt duidelijk naar voren uit het arrest Van Rooij/Erven van der Sluijs.

Van der Sluijs c.s., eigenaren van een woonhuis, vorderen ontruiming daarvan door de bewoner Van Rooij. Zij kwalificeerden de rechtsverhouding tot Van Rooij als bruikleen, maar deze voerde als verweer dat hij de woning had gehuurd. De ontruiming wordt toegewezen, waarbij de rechter de rechtsverhouding als huur kwalificeert. De bewoner klaagt bij de Hoge Raad dat de rechter de ontruiming niet had mogen bevelen op een andere grondslag dan de door de eigenaren gestelde bruikleen. De Hoge Raad verwerpt die klacht:

'In haar algemeenheid is onjuist de opvatting dat, indien de rechter tot de slotsom komt dat de werkelijk tussen partijen bestaande rechtsverhouding een andere is dan door de eiser gesteld, de door eiser ingestelde vordering niet op grondslag van die andere rechtsverhouding kan worden toegewezen. Zij miskent dat het enkele feit dat een eisende partij de aan haar vordering ten grondslag gelegde rechtsverhouding onjuist heeft gekwalificeerd, de rechter niet ontslaat van zijn uit art. [25] $\mathrm{Rv}$ voortvloeiende verplichting om ambtshalve en onafhankelijk van enige door die partij aangehangen rechtsbeschouwing te onderzoeken of de door deze tijdens het geding aan haar vorderingen ten grondslag gelegde feiten die vorderingen kunnen dragen. Dat is slechts anders, indien moet worden aangenomen dat de eisende partij haar vordering uitsluitend beoordeeld wenste te zien op basis van een rechtsverhouding die aan die kwalificatie beantwoordt. Dit geval doet zich hier niet voor. Van der Sluijs c.s. hebben immers reeds in een op 23 augustus I988 genomen memorie gesteld dat aan de zijde van Van Rooij sprake was van een zodanig grove wanprestatie, dat de tussen partijen gesloten overeenkomst, of dit nu een bruikleenovereenkomst of een huurovereenkomst was, ontbonden diende te worden.' ${ }^{78}$

De kern van de geciteerde overwegingen is gelegen in de zin dat de rechter de verplichting heeft om ambtshalve en onafhankelijk van enige door de eisende partij aangehangen rechtsbeschouwing te onderzoeken of de door deze tijdens het geding aan haar vorderingen ten grondslag gelegde feiten die vorderingen kunnen dragen. Uiteraard geldt dit in voorkomend geval ook voor de verwerende partij. Deze terminologie blijft dicht bij de grondslagen waarover art. 24 Rv spreekt. Bovendien wordt niet als criterium genoemd of de desbetreffende partij de verkeerde rechtsregel heeft ingeroepen, maar of de feiten die door de partij tijdens het geding ten grondslag zijn gelegd aan haar vordering c.q. verweer die vordering of dat verweer kunnen dragen. Uiteraard gaat het daarbij om rechtsfeiten, rechtsgevolgen, rechtsregels, maar de formulering is zo gekozen dat wat de partij zelf aan juridische kwalificaties daaraan verbindt niet van belang is omdat de rechter zelfstandig op

78 HR I5 mei 1998, NJ 1998/625 (Van Rooy/Erven van der Sluijs). 
zoek moet gaan naar regel en rechtsgevolg. Maar heeft hij dan wel altijd de beschikking over de geschikte rechtsfeiten om bij zijn zoektocht van uit te gaan? Dat is natuurlijk de vraag - zie daarover $\$ 3 \cdot 4 \cdot 3$. Het uitgangspunt is echter wat de partij zelf aan feiten aan zijn vordering c.q. verweer ten grondslag heeft gelegd. In dit grensgebied begeeft de rechter zich soms als hij vindt dat de ingeroepen rechtsgronden moeten worden gewijzigd. In de volgende paragraaf wordt daarop ingegaan.

In de laatste twee zinnen van het hierboven geciteerde gedeelte uit het arrest komt een uitzondering voor die berust op de autonomie van de eisende partij (of in voorkomend geval natuurlijk de verweerder) om het geschil beoordeeld te zien uitsluitend op de door haar aangevoerde rechtsgrond. Dat komt niet zo vaak voor en mag ook niet te snel worden aangenomen, zeker als de ambtshalve toepassing van de door de rechter toepasselijk geachte rechtsgrond leidt tot een voor die partij gunstige uitkomst. Het blijft een echte uitzondering en mag zeker niet worden omgekeerd zoals gebeurt in het in de volgende paragraaf genoemde arrest Post/ Kleijweg, want dan wordt te veel afbreuk gedaan aan de verplichting die de rechter door art. $25 \mathrm{Rv}$ wordt opgelegd.

\subsubsection{Afbakening t.o.v. de verboden aanuulling van feitelijke gronden}

Hiervoor in $\S 3.3 . \mathrm{I}$ hebben we gezien dat de grondslagen van vordering of verweer zowel feitelijke als juridische elementen bevatten, elementen die op elkaar inwerken. Bij de noodzakelijke analyse die de rechter moet maken in verband met eventuele aanvulling van rechtsgronden en de bepaling van de grenzen van zijn bevoegdheid daartoe, zullen de daarvoor relevante grondslagen aan de hand van die elementen moeten worden gedefinieerd. Het ligt voor de hand om de ingeroepen rechtsgevolgen tot uitgangspunt te nemen want die leiden de rechter tot de feiten en tot de rechtsnorm die bepaalt aan welke feiten die rechtsgevolgen zijn verbonden.

Aan de feitelijke basis voor de ambtshalve aanvulling van rechtsgronden heeft de Hoge Raad in een recent arrest, waarin een loepzuiver voorbeeld van toelaatbare ambtshalve aanvulling van rechtsgronden aan de orde was, ${ }^{79}$ overwegingen gewijd.

De zaak betrof een erfdienstbaarheid van weg die in het kader van een reconstructie van een gebied (Midden-Delfland) van rechtswege was vervallen als gevolg van een fout van het Kadaster of van de Reconstructiecommissie. De eigenaren van het heersende erf vorderden van de eigenaren van het dienende erf medewerking aan vestiging van een nieuwe erfdienstbaarheid, welke medewerking werd geweigerd. Het hof was van oordeel, met aanvulling van rechtsgronden, dat in de stellingen van de eigenaren van het heersende erf dat de eigenaren van het dienende erf een onterecht voordeel genieten door misbruik te maken van de gemaakte fout en dat eerstgenoemden door dat misbruik nadeel lijden, een beroep besloten ligt op ongerechtvaardigde verrijking. Het hof heeft bij pleidooi dit oordeel op voorhand aan partijen voorgehouden en hun de gelegenheid gegeven zich daarover uit te laten. Het heeft het beroep op ongerechtvaardigde verrijking gegrond geoordeeld, overwogen dat schadevergoeding ook in natura kan plaatsvinden en vastgesteld dat de vordering van de eigenaren van het heersende erf hier naadloos op aansluit en derhalve toewijsbaar is. 
De Hoge Raad overweegt dat voor die ambtshalve aanvulling noodzakelijk, maar ook voldoende, is dat een partij zodanige feitelijke stellingen aan haar vordering ten grondslag legt dat deze - eventueel in onderling verband en samenhang bezien, mits voor zowel de rechter als de wederpartij duidelijk genoeg is dat de desbetreffende stellingen (mede) in die samenhang of dat verband ten grondslag worden gelegd aan de vordering - toewijzing van de vordering kunnen rechtvaardigen op de door de rechter bij te brengen rechtsgrond. De Hoge Raad respondeerde hiermee op een cassatieklacht die inhield dat het hof door de vordering op basis van een andere dan door de eisers gestelde rechtsgrond te onderzoeken en toe te wijzen, in strijd met het recht een rechtsgrond heeft aangevuld, nu de eisers niet (duidelijk genoeg) te kennen hadden gegeven toewijzing van de vordering op deze grondslag te wensen. Dat is een spiegelbeeldige redenering van die welke we tegenkwamen aan het slot van de in de vorige paragraaf besproken overweging in het arrest Van Rooij/Erven van der Sluijs. Ook daarom kon die redenering niet slagen omdat zij een eis stelt die niet geldt. Het criterium is volgens dat arrest immers niet dat de eiser te kennen heeft gegeven dat hij die ambtshalve rechtstoepassing wenste maar of aangenomen moet worden dat hij die niet wenste.

De Hoge Raad laat de rechter veel ruimte om de feitelijke grondslag voor de ambtshalve rechtstoepassing aanwezig te achten en daartoe de stellingen te interpreteren, met dien verstande dat hij daarbij rekening moet houden met wat de wederpartij mocht begrijpen en verwachten. De belangrijkste voorwaarde is immers dat het voor rechter en wederpartij duidelijk genoeg is dat de desbetreffende feitelijke stellingen door de verweerder aan de vordering (of in voorkomend geval door de verweerder aan het verweer) ten grondslag zijn gelegd. De ambtshalve aanvulling moet dus plaatsvinden binnen de door de feitelijke grondslag van eis c.q. verweer omlijnde grenzen van de rechtsstrijd (art. $24 \mathrm{Rv}$ ). Een simpel voorbeeld van aanvulling en interpretatie kwamen we hierboven in $\$ 3.2$ al tegen in HR I7 oktober 20I4, ECLI:NL:HR:20I4:3000.

\subsubsection{De rechter mengt zich in de zaak}

\subsubsection{Vier verkeerslichten: twee groene en twee rode}

De rechter komt op verboden terrein als hij ten behoeve van de ambtshalve toepassing van een niet door partijen ingeroepen rechtsregel en de door die regel geëiste rechtsfeiten, feiten nodig heeft die niet voorkomen in de feitelijke grondslag van vordering of verweer. In dat geval dreigt hij buiten de grenzen van de rechtsstrijd te komen indien hij die feiten gaat zoeken in het dossier (denk aan art. I49 Rv dat hier de weg wijst) waarop de partijen zich niet hebben beroepen. Vindt de rechter het echter nodig om de feitelijke grondslag van vordering of verweer aan te vullen om met toepassing van een ambtshalve bijgebrachte rechtsgrond recht te doen of heeft hij in het licht van het hierboven genoemde criterium gerede twijfel of de bestaande feitelijke grondslag voldoende basis biedt voor die toepassing, dan zal hij de partijen dit moeten voorleggen. Hierboven in $\S 3 \cdot 3 \cdot 2.3 \mathrm{kwam}$ al ter sprake dat de Hoge Raad de overschrijding van de grenzen van de rechtsstrijd in het teken van het beginsel van hoor en wederhoor zet. Maar dan komt de procedurele vraag of dit nog mogelijk is in het inmiddels bereikte stadium van het proces. 
Met het voorgaande houdt ook verband het geval dat de rechter meent dat een partij een feitelijke of juridische grond, bijvoorbeeld een verweermiddel, niet heeft aangevoerd waartoe de zaak volgens de rechter wel aanleiding gaf op grond van de in de zaak in het algemeen toepasselijke rechtsregels. De rechter mag de rechtsregel waarop die grond of dat verweermiddel berust dan niet ambtshalve toepassen op de feiten die vaststaan omdat hij daarmee de door art. $24 \mathrm{Rv}$ bepaalde grenzen van de rechtsstrijd zou overschrijden. De wet kent overigens enkele bepalingen waaruit dat in bepaalde gevallen expliciet volgt. Zo verbiedt art. 3:322 BW de rechter ambtshalve het middel van verjaring toe te passen en verbiedt art. 236 lid $3 \mathrm{Rv}$ de rechter ambtshalve het gezag van gewijsde van een uitspraak toe te passen.

In vier uitspraken heeft de Hoge Raad op dit punt verkeerslichten neergezet ten aanzien van de vraag of de rechter in zo'n geval een dergelijke grond of verweer aan de orde mag stellen. Eerst twee groene lichten: de rechter mocht het wel, en dan twee rode: de rechter mocht het niet. In het arrest Regiopolitie Gelderland-Zuid/ $\operatorname{Hovax}^{80}$ betrof het een niet gevoerd maar volgens de appelrechter relevant eigenschuldverweer (art. 6:IOI BW).

Hovax had een bedrijfspand verhuurd aan Regiopolitie ${ }^{8 \mathrm{r}}$ maar laatstgenoemde stelde zich op het standpunt dat met haar geen huurovereenkomst tot stand was gekomen. Als gevolg hiervan leed Hovax schade waarvan zij in deze procedure vergoeding vorderde van Regiopolitie. De rechtbank - als appelrechter - stelde ambtshalve in een tussenvonnis de vraag aan de orde of Hovax schadebeperkende maatregelen had genomen die in de gegeven omstandigheden redelijkerwijs van haar konden worden gevergd. Zij gelastte daarover een deskundigenbericht. Op basis daarvan oordeelde de rechtbank bij eindvonnis dat Hovax over een bepaalde periode dat het verhuurde leeg stond ten onrechte geen schadebeperkende maatregelen had genomen. De rechtbank verminderde op grond daarvan de schadevergoeding.

Hovax komt daartegen op in cassatie. Zij stelt dat de rechtbank buiten de grenzen van de rechtsstrijd is getreden door dit onderwerp in haar tussenvonnis aan de orde te stellen, hoewel daarop tot op dat moment door de Regiopolitie geen beroep was gedaan.

De Hoge Raad overweegt:

'5.2 Het is op zichzelf juist dat de rechter een wettelijke verplichting tot schadevergoeding niet ambtshalve mag verminderen op de grond dat naar zijn oordeel - kort gezegd - sprake is van "eigen schuld" van de benadeelde aan zijn schade, ook al wordt (aldus de MvA II bij art. 6:Ior, Parl. Gesch. Boek 6, blz. 353) "de vergoedingsplicht (...), wanneer aan de eisen van het artikel is voldaan, van rechtswege verminderd (...)". Het mede in art. 6 EVRM verankerde fundamentele beginsel van hoor en wederhoor brengt mee dat de rechter pas tot die vermindering mag overgaan indien de aansprakelijk gestelde persoon een voldoende gemotiveerd beroep op eigen schuld van de benadeelde aan zijn schade heeft gedaan. Anders dan het onderdeel betoogt, betekent dit echter niet dat het de rechter nimmer zou vrijstaan de eigen-schuld-vraag ambtshalve aan de orde te stellen. Uit het hiervoor overwogene volgt wél dat hij, als hij dat doet, partijen in de gelegenheid dient te stellen het processuele debat dienaangaande aan te gaan en dat hij zich van een beslissing op dit punt dient te onthouden als vervolgens blijkt dat partijen dat debat niet wensen te voeren.

80 HR 26 september 2003, NJ 2004/46o.

8I Of de huurovereenkomst tot stand was gekomen, was ook een vraag die uiteindelijk bevestigend werd beantwoord. 
5.3 De vraag wanneer het de rechter vrijstaat deze kwestie ambtshalve aan de orde te stellen, kan niet in haar algemeenheid worden beantwoord. Het onderhavige geval wordt echter daardoor gekenmerkt dat het partijdebat in eerste aanleg en in hoger beroep tot aan het eerste tussenvonnis van de rechtbank, zich had beperkt tot de vraag of aansprakelijkheid van de Regiopolitie tegenover Hovax bestond, c.q. of de door Hovax gestelde huurovereenkomst al dan niet tot stand was gekomen. Onder deze omstandigheden lag het, nadat de rechtbank had geoordeeld dat Hovax in het tot dan toe gevoerde debat het gelijk aan haar zijde had, zozeer voor de hand dat de Regiopolitie - die al eerder had gesteld dat het pand inmiddels zou zijn verhuurd en dat Hovax zich daarover diende uit te laten - vervolgens een beroep zou willen doen op eigen schuld van Hovax aan haar schade, dat het de rechtbank vrijstond deze vraag ambtshalve aan de orde te stellen.'

In het verlengde van deze uitspraak ligt het arrest X/Mr. Aerts q.q. (faillissementscurator) van ruim vier jaar later. ${ }^{82}$

De zaak betreft de aansprakelijkheid van de bestuurder van de gefaillieerde vennootschap [A] voor het tekort in het faillissement van de vennootschap. Die aansprakelijkheid volgt uit art. 2:248 BW indien de bestuurder zijn taak kennelijk onbehoorlijk heeft vervuld en aannemelijk is dat dit een belangrijke oorzaak is van het faillissement. Volgens lid 7 van dat artikel wordt voor de toepassing van dit artikel met een bestuurder gelijkgesteld degene die het beleid van de vennootschap heeft bepaald of mede heeft bepaald, als ware hij bestuurder.

In deze zaak was NVR weliswaar niet formeel bestuurder van de gefailleerde vennootschap, maar is zij volgens het hof wel als mede-beleidsbepaler mogelijk op de voet van art. 2:248 lid 7 BW ansprakelijk te houden als ware zij bestuurder. Omdat dit oordeel zou neerkomen op een verrassingsbeslissing, stelt het hof partijen in de gelegenheid zich hierover uit te laten.

Daartegen komt NVR in cassatie op. Betoogd wordt dat het hof heeft miskend dat het de rechter niet vrijstaat zijn oordeel te baseren op rechtsgronden die weliswaar zouden kunnen worden afgeleid uit de in het geding gebleken feiten of omstandigheden doch die door de desbetreffende partij niet aan haar vordering ten grondslag zijn gelegd. De Hoge Raad overweegt:

'4.3.2 Het onderdeel faalt. Het hof heeft eerst vastgesteld dat NVR niet op grond van een rechtsgeldig genomen besluit is benoemd tot bestuurder van [A] en vervolgens overwogen dat uit de stellingen van partijen wel kan worden afgeleid dat NVR via Za. is opgetreden als mede-beleidsbepaler van [A]. Hieruit heeft het hof de conclusie getrokken dat voor toewijzing van de vordering van de curator de grondslag moet worden gevonden in art. 2:248 lid 7 in verbinding met lid I en/of lid 2 en art. 2:II BW, doch dat de curator zijn vordering daarop niet heeft gebaseerd omdat hij meende dat NVR wél tot bestuurder was benoemd. Het hof heeft terecht overwogen dat het daarom de vordering niet op die grondslag mocht toewijzen, omdat het hof daarmee niet alleen, zoals het heeft onderkend, het beginsel van hoor en wederhoor zou hebben geschonden, maar ook omdat het daarmee buiten de rechtsstrijd van partijen zou zijn getreden. Het stond het hof echter, gelet op het verloop van het processuele debat, vrij de curator in de gelegenheid te stellen zich uit te laten over een, zoals in dit geval voor de hand lag, op art. 2:248 lid 7 in verbinding met lid I en/of lid 2 en art. 2:II BW te baseren aansprakelijkheid van [A]. Daarbij verdient opmerking dat voor heropening

82 HR I4 maart 2008, NJ 2008/466 (m.nt. JMM Maeijer en HJ Snijders). 
van het partijdebat aanleiding werd gevonden in de omstandigheid dat inmiddels bij het getuigenverhoor feiten aan het licht waren gekomen die wezen op aansprakelijkheid op grond van een ander lid van dezelfde bepaling die al aan de vordering wegens bestuurdersaansprakelijkheid ten grondslag was gelegd. Nu de curator vervolgens de grondslag van zijn vordering heeft aangevuld met de stelling, zoals het hof deze heeft opgevat, dat NVR via $\mathrm{Za}$. is opgetreden als mede-beleidsbepaler van [A] en [A] tegen deze aanvulling geen bezwaar heeft gemaakt, mocht het hof de vordering tot betaling van I.000.000 op deze nieuwe grondslag beoordelen.'

De rechter mag dus nieuwe gronden en weren aan de orde stellen als het debat daartoe aanleiding geeft, als dit - anders gezegd - 'voor de hand ligt'. Om verrassingsbeslissingen te voorkomen moet het debat dan worden heropend. Van belang is dat in het arrest X/mr. Aerts q.q. de Hoge Raad het hof toestaat recht te doen op de nieuwe grondslag omdat de curator die had overgenomen.

Hoe heel anders liep het in twee zaken waarin de Hoge Raad kort na elkaar arrest heeft gewezen; de rode lichten. In de eerste plaats de zaak Pessers/Ru-Pro. ${ }^{83}$

Ru-Pro verkoopt een bedrijfspand aan Pessers tot zekerheid met een recht tot terugkoop ('de aanvullende overeenkomst). Nadien wordt het pand doorverkocht aan een derde. Het geschil tussen Ru-Pro en Pessers betreft de afdracht aan Ru-Pro van de opbrengst van die doorverkoop.

Op de pleitzitting stelt het hof aan de orde dat de verkoop aan Pessers nietig was vanwege het verbod van overdracht van een goed tot zekerheid (fiduciaverbod) in art. 3:84 lid $3 \mathrm{BW}$. In het daarop volgende debat volgt in verband met die nietigheid van de verkoop een eiswijziging van Ru-Pro, welke door het hof wordt geaccepteerd. Daartegen richt zich het cassatieberoep van Pessers.

De Hoge Raad overweegt dat de eiswijziging gelet op de strakke procedureregels in appel niet had mogen worden aanvaard door het hof. Voorts overweegt hij: 'De stukken van het geding laten, ten slotte, niet het oordeel toe dat daarin zo duidelijke aanwijzingen zijn gelegen dat de aanvullende overeenkomst strekte tot het verschaffen van een met de wettelijke zakelijke zekerheidsrechten vergelijkbaar verhaalsrecht als bedoeld in art. 3:84 lid 3 [BW], dat het aan de orde stellen van dit thema binnen de grenzen van de door partijen bepaalde rechtsstrijd voor de hand lag. Integendeel: de mogelijke toepasselijkheid van het fiduciaverbod bracht - in de eindfase van de procedure in hoger beroep - een geheel nieuw element in het tussen partijen gevoerde debat.'

Een gelijksoortige beslissing is te vinden in het arrest Doornenbal/Van der Spek, ${ }^{8}{ }^{4}$ waarin het hof de nietigheid aan de orde stelt van een afstandsbeding van de gebruiker van de grond waarom het in deze zaak ging ${ }^{85}$ en dit vervolgens als verweer wordt overgenomen in een laat stadium van de procedure. Dat verweer lag volgens de Hoge Raad echter niet 'in het verlengde' van de reeds door partijen omlijnde rechtsstrijd in appel.

83 HR 23 september 20II, NJ 2013/6 (m.nt. H.J. Snijders).

84 HR 9 december 20II, NJ 2013/7 (m.nt. H.J. Snijders).

85 Het betrof het volgende beding: 'Bij eventuele onteigening zal huurder in de gelegenheid worden gesteld de voor dat jaar geldende oogst te oogsten. Verhuurder is bij onteigening geen schadevergoeding verplicht jegens huurder.' 
In beide gevallen heeft het hof naar het oordeel van de Hoge Raad door de uitbreiding van het verweer te aanvaarden, de door de goede procesorde op dit punt gestelde grenzen miskend. 'Dat wordt niet anders doordat het hof zelf dit verweer aan de orde heeft gesteld, omdat voor de grondslag waarop het hof heeft te beslissen niet bepalend is wat het hof aan de orde heeft gesteld maar, ingevolge art. $24 \mathrm{Rv}$, hetgeen de partijen aan hun vordering en verweer ten grondslag hebben gelegd en ten grondslag mochten leggen gelet op de goede procesorde in verband met het stadium waarin de procedure zich bevond. ${ }^{96}$

\subsubsection{De conclusie uit de vier arresten: wat ligt wel of niet voor de hand?}

Men kan zeggen dat de arresten Regiopolitie/Hovax en X/mr. Aerts q.q. voor beide instanties zijn geschreven, waarbij laatstgenoemd arrest laat zien dat als uit bewijslevering blijkt dat de kaarten anders liggen, dit een reden kan zijn om in een laat stadium van de procedure het debat te heropenen over de rechtsgronden. Echter de arresten Pessers/Ru-Pro en Doornenbal/Van der Spek hangen duidelijk samen met het strakke processysteem in appel. Maar in beide zaken speelt ook een rol dat de aanvulling van rechtsgronden berustte op een (mogelijk) onjuiste rechtsopvatting van het hof. In de zaak Pessers/Ru-Pro leverden de stukken van het geding niet zo duidelijke aanwijzingen op dat de 'aanvullende overeenkomst' een met het fiduciaverbod strijdige strekking had - lees: daarvoor was dus in het debat van partijen geen steun te vinden. Dan houdt het verhaal eigenlijk al meteen op. In de zaak Doornenbal/Van der Spek oordeelde de Hoge Raad dat het afstandsbeding niet nietig was maar vernietigbaar en daarom geen rechtsregel van openbare orde betrof. In zo'n geval ligt het inderdaad ook geenszins voor de hand om daarover het debat te openen. Kortom, de beide rode lichten werden ook - en misschien wel vooral gegeven vanwege inhoudelijk ten minste kwestieuze rechtsopvattingen van het hof. Dat was niet het geval bij Regiopolitie/Hovax en X/mr. Aerts q.q., waarin de aanvulling van rechtsgronden in het licht van de feiten die waren komen vast te staan inderdaad voor de hand lag, in laatstgenoemde zaak overigens wat meer dan in de eerstgenoemde. Het criterium geeft op het eerste gezicht niet veel houvast maar het wordt wat meer geconcretiseerd met 'in het verlengde liggen van de reeds door partijen omlijnde rechtsstrijd' in het arrest Doornenbal/Van der Spek. Maar nogmaals: de rechter moet wel het recht waarmee hij de rechtsgronden wil aanvullen goed beheersen.

Een aspect dat in geen van de arresten door de Hoge Raad expliciet is genoemd, is het gevaar dat de rechter zijn onpartijdigheid verliest als hij met aanvullende voorstellen komt die te ver afliggen van de rechtsstrijd die door partijen is omlijnd. Dat gevaar kan niet worden gekeerd met enkel de fundamentele waarborg van het recht van hoor en wederhoor, want die ziet op het kunnen reageren op het voorstel. Hier kan echter (de schijn van) een niet onpartijdige mentale instelling van de rechter spelen. Het doen van het voorstel zou namelijk al kunnen suggereren dat de rechter wil gaan 'meeprocederen'. Daarmee wordt bedoeld dat de rechter zich gaat opstellen als een partij in het proces: hij neemt tijdens het proces open-

Zie over deze arresten ook De Groot 20I2/4.6.4-4.6.6. 
lijk een standpunt in waarmee hij het proces stuurt in de richting van een door hem beoogde beslissing en niet enkel een door hem nodig geacht (voortgezet) debat. Door het eerste sluit hij zich prematuur af voor argumenten van de partij die een andere beslissing nastreeft. Deze partij heeft dan geen mogelijkheid meer om tot het laatst in de procedure het oordeel van de rechter te beïnvloeden, welke mogelijkheid trouwens ook ten grondslag ligt aan het recht van hoor en wederhoor en het beginsel van equality of arms. Van dat - subjectieve - verlies van onpartijdigheid hoeft geen sprake te zijn, maar de schijn kan wel gewekt worden en dat is al voldoende voor schending van het grondrecht op een onpartijdige rechter. Het is dus van belang dat als de rechter suggesties of voorstellen doet tot wijziging van de grenzen van de rechtsstrijd, hij zijn onpartijdigheid door een naar buiten blijkende onpartijdige houding bewaakt. Hij kan dat doen door zich dienend (faciliterend) op te stellen. De rechter blijft immers een dienende taak houden: hij moet het geschil van partijen beslechten en mag dit niet naar zich toe trekken. ${ }^{87}$ De aanvulling van rechtsgronden en de daarmee samenhangende uitbreiding van het feitelijke debat moeten dienstbaar zijn aan een rechtvaardige beslissing in het geschil tussen partijen en mogen geen elementen in het proces brengen die helemaal niet thuishoren in de door het partijdebat omlijnde rechtsstrijd. Daarmee wordt niet de partijautonomie op de stoel van de rechter gezet. Partijen kunnen de rechtsstrijd verkeerd hebben omlijnd omdat ze vanuit de optiek van een juiste rechtstoepassing niet de goede keuzes hebben gemaakt. De rechter die wakkt over de rechtstoepassing op de feiten zal dan moeten corrigeren, en die correctie betreft dan uiteraard ook de kwalificatie van de feiten. Dit kan als gezegd eerst blijken tijdens het verloop van de procedure, als de feiten wat meer uit de verf komen. Het is dan de plicht van de rechter om bij te sturen en dit met partijen te bespreken. Dat geldt ook in appel, met name wanneer daarin bewijslevering heeft plaatsgevonden. Want de hiervoor genoemde strakke regels gelden dan wel als basis, maar feitelijk onderzoek in hoger beroep wordt er bepaald niet door verboden, evenmin als aanpassing van de rechtsstrijd als die na dat onderzoek nodig blijkt. Dat leren de twee groene lichten.

\subsubsection{Aanvullen van feitelijke gronden ten dienste van de juiste rechtstoepassing}

In de vorige paragrafen is uitvoerig stilgestaan bij het aanvullen van rechtsgronden doordat de rechter kwalificaties introduceert of rechtsregels toepast (al of niet na dit aan partijen te hebben voorgesteld of voorgelegd) waarop geen van de partijen zich heeft beroepen. Mag de rechter ten dienste van de ambtshalve aanvulling van rechtsgronden die hij nodig acht partijen uitnodigen de feitelijke gronden (rechtsfeiten) aan te vullen?

In haar hiervoor al meermalen genoemde preadvies voor de Nederlandse Juristen-Vereniging wil De Groot dat mogelijk maken en art. 25 Rv daartoe aanvullen. De nieuwe tekst zou dan luiden:

87 Over de dienende taak van de rechter en onpartijdigheid in verband met aanvulling van rechtsfeiten ten dienste van de waarheidsvinding maakt De Groot 2012/473 behartenswaardige opmerkingen. 
'1. De rechter vult ambtshalve de rechtsgronden aan die bestaan uit de toepassing van een rechtsregel.

2. Ten dienste van de waarheidsvinding in het geschil van partijen kan de rechter ambtshalve rechtsgronden aanvullen die een feitelijk element bevatten, mits een partij op het feitelijk element een beroep heeft gedaan'. ${ }^{88}$

Als ik het goed zie, ligt de kern van het tweede lid hierin dat de rechter met het oog op de door hem nodig geachte aanvulling met een rechtsgrond die een feitelijk element bevat, de partij die het aangaat voorstelt de feitelijke grondslag van haar vordering of verweer uit te breiden met feiten waaraan de door de rechter te introduceren rechtsgrond rechtsgevolg verbindt. Het is De Groot te doen om met dit voorstel de waarheidsvinding te verbeteren: onderzoek naar de feiten die relevant zijn voor een beslissing van het geschil op basis van de door de rechter juist geoordeelde rechtsregels. Wat zij voorstelt, vloeit in wezen al voort uit de rechtspraak. Waar de rechter aan partijen een niet in grondslagen van vordering of verweer voorkomende rechtsgrond voorlegt die volgens hem zou kunnen of moeten worden toegepast, impliceert dit dat de partij die ervan profiteert die rechtsgrond en de daarbij behorende rechtsfeiten in zijn grondslag opneemt. De wederpartij kan daartegen uiteraard verweer voeren, maar de rechtsgrond en het rechtsfeit zijn daarmee onderdeel van het debat geworden. De rechtspraak van de Hoge Raad die hiervoor in $\$ 3.4 .4$ is besproken, raakt vooral de vraag of dat allemaal nog wel mogelijk was. De Groot wil die vraag, als ik het goed zie, bij voorbaat bevestigend beantwoorden ter wille van de waarheidsvinding. Ik ben het daarmee eens, niet alleen vanuit de optiek van de waarheidsvinding maar ook vanuit de optiek van een gezamenlijk gedragen verantwoordelijkheid van partijen en rechter voor een behoorlijk proces waarin het gaat om de werkelijke en rechtens relevante rechtsfeiten en rechtsgevolgen. ${ }^{89}$

\subsubsection{Aanvulling van rechtsgronden in cassatie}

Tot zover stond de ambtshalve aanvulling van rechtsgronden door de feitenrechter (rechtbank en gerechtshof) centraal. In cassatie is een groot deel van de problematiek niet relevant. Daar bestaat immers geen ruimte voor feitelijke nova en in de procedure na cassatie en verwijzing is de ruimte daarvoor beperkt. Aanvullen van feitelijke gronden is dus in cassatie niet aan de orde.

Het op art. 4I9 lid I $\mathrm{RV}^{9 \circ}$ berustende 'middelenstelsel' in cassatie brengt mee dat de Hoge Raad een uitspraak van het hof niet mag vernietigen op basis van ambtshalve door hem bijgebrachte gronden, dat wil zeggen zonder dat een cassatiemiddel is ingebracht tegen de beslissing van het hof die vernietigd wordt. De Hoge Raad is zeer strikt in de toepassing van deze procesregel, met dien verstande dat het Europese recht ambtshalve cassatie voorschrijft als het hof zich in strijd met

88 Het voorstel werd samengevat voor de discussie in vraagpunt 2: 'Het verdient aanbeveling in art. 25 Rv ook tot uitdrukking te brengen dat de rechter in het geschil van partijen naar waarheid dient te beslissen.' Dit vraagpunt werd met een kleine meerderheid ontkennend beantwoord. Zie daarover Handelingen NJV 20I2-2.

89 Dat zal haar niet verbazen. Zie Asser, Groen \& Vranken 2003/6.3.3 en 2006/5.5-5.6.

90 Lid I van dat artikel luidt: 'De Hoge Raad bepaalt zich bij zijn onderzoek tot de middelen waarop het beroep steunt.' 
de Europese bevoegdheidsregels niet onbevoegd had verklaard. ${ }^{\text {I }}$ Intussen wordt in de literatuur ${ }^{92}$ verdedigd om ambtshalve cassatie mogelijk te maken en daarvoor zijn goede gronden. ${ }^{93}$ Het middelenstelsel is door de Hoge Raad zelf vormgegeven op grond van een zeer strikte uitleg van art. 4I9 Rv. In principe is dat ook wel praktisch, maar principieel niet vereist. Afgezien daarvan geldt ook voor de cassatierechter art. $25 \mathrm{Rv}$ in de zin dat hij op grond van een cassatiemiddel mag casseren met aanvulling van de rechtsgronden, dus rechtsgronden waarop het middel zich niet beroept. ${ }^{44}$ Dat komt regelmatig voor zonder dat de Hoge Raad, gekluisterd aan zijn middelenstelsel, het met zoveel woorden zegt. De techniek die daarvoor wordt gebruikt, is interpretatie van het middel en daarin inlezen van de juiste rechtsgrond. Dit toont trouwens al aan dat het ook eenvoudiger zou kunnen door met zoveel woorden de rechtsgrond aan te vullen. Verwerping van het beroep op ambtshalve bijgebrachte gronden gebeurt ook regelmatig. Daar kan de Hoge Raad open kaart spelen omdat hij dan niet wordt belemmerd door het middelenstelsel (geen vernietiging zonder middel); er wordt voor de verwerping van de klachten immers geen daartoe strekkend verweer geëist.

Intussen moet het voorgaande niet doen vergeten dat het cassatieberoep er ook voor is om aanvulling van rechtsgronden waar die verplicht was maar door de feitenrechter was nagelaten alsnog op de agenda te krijgen. Over schending van art. $25 \mathrm{Rv}$ kan uiteraard geklaagd worden. Langs die route kunnen zelfs na vernietiging door de cassatierechter en verwijzing van de zaak teneinde alsnog de toepasselijke rechtsregels toe te passen, de feitelijke gronden worden aangevuld die voor die toepassing nodig zijn, als de Hoge Raad dat toestaat, bijvoorbeeld omdat hij de toe te passen rechtsregels (opnieuw) heeft geformuleerd, maar ook in het geval dat sprake is van regels van openbare orde (daarover meer in de volgende paragraaf).

In de prejudiciële procedure ${ }^{95}$ heeft de Hoge Raad uiteraard veel meer armslag. Centraal staat daarin niet de beslissing van de zaak maar de beantwoording van de prejudiciële vragen. Hij is niet gebonden aan de feiten die de rechter die de vraag stelt voorlopig heeft vastgesteld met het oog op de vraag. Later in een eventuele cassatieprocedure in de zaak is de Hoge Raad als cassatierechter niet gebonden aan zijn antwoord.

\subsubsection{Dwingend recht en openbare orde}

\subsubsection{Inleiding}

Hiervoor in $\$$ 3.4.I hebben we als tweede functie van art. $25 \mathrm{Rv}$ genoemd de rechtshandhaving. Die geldt in versterkte mate voor de ambtshalve toepassing van

9I HvJ EG I5 november I983, NJ I984/695 (Mr. Duijnstee q.q./Goderbauer).

92 Ik verwijs kortheidshalve naar Asser Procesrecht. Korthals Altes \& Groen 7 2015/273-275.

93 Voor dit aspect verwijs ik ook naar de preadviezen van collega Ivan Verougstraete (hoofdstuk 4) en mij (hoofdstuk 7) voor de vergadering van onze Vereniging in 2007, Den Haag: Boom Juridische uitgevers 20II.

94 Asser Procesrecht. Korthals Altes \& Groen 7 2015/276.

95 Art. 8I van de Wet op de Rechterlijke Organisatie; art. 392-394 Rv. Zie daarover Asser Procesrecht. Korthals Altes \& Groen 7 2015/338-34I. 
dwingend recht en recht van openbare orde. Voor dwingend recht dat niet van openbare orde is, gelden de gewone regels die hierboven zijn uiteengezet. De rechter mag bij de aanvulling van regels van dwingend recht die niet van openbare orde zijn de grenzen van de rechtsstrijd niet overschrijden.

Ten aanzien van het begrip openbare orde in de context van ons onderwerp bestaat geen maximale duidelijkheid. ${ }^{6}$ Waar de wet spreekt van rechtsgevolgen die niet ter vrije bepaling van partijen staan, zoals in art. $149 \mathrm{Rv},{ }^{97}$ wordt tot uitdrukking gebracht dat partijen niet vrijelijk die rechtsgevolgen kunnen uitsluiten of veranderen. Dat houdt verband met het bij de desbetreffende rechtsgevolgen betrokken algemeen belang of de daarbij betrokken fundamentele rechtsbeginselen.${ }^{9}$ Elders spreekt de Hoge Raad met het oog op de ambtshalve rechtstoepassing van: '[een bepaling ter] bescherming van algemene belangen van zo fundamentele aard dat zij (ongeacht het partijdebat of de bijzondere omstandigheden van het geval) altijd door de rechter moet worden toegepast'. ${ }^{99}$ Men zou ook kunnen spreken van 'superdwingend recht'. ${ }^{\text {100 }}$

Het zijn overigens lang niet altijd voor de samenleving fundamentele rechten en rechtsgevolgen die van openbare orde zijn. Het kan ook gaan om fundamentele ordeningsprincipes die de rechtszekerheid dienen. Zo zijn procesrechtelijke termijnen (bijvoorbeeld beroepstermijnen) van openbare orde, wat betekent dat de rechter ze ambtshalve moet toepassen. ${ }^{\text {Ior }}$

De rechter zal telkens moeten nagaan of een bepaling van dwingend recht ook van openbare orde is, in welk geval hij tot ambtshalve toepassing moet overgaan, ook als hij daarmee zou treden buiten de grenzen van de rechtsstrijd.

Een voorbeeld van een rechtsgevolg van - mijns inziens - openbare orde in de sfeer van het dagelijks leven en de wijze waarop de Hoge Raad het karakter van de rechtsregel vaststelt, levert HR 27 september 2013, ECLI:NL:HR:2013:CAI970.

Het proces gaat over alimentatie na echtscheiding. Voor de echtscheiding tussen partijen in 1997 hebben zij een alimentatieovereenkomst gesloten. Op grond hiervan diende de man alimentatie aan de vrouw te betalen. De man houdt in 2009 op met betalen.

96 Zie over dit begrip Asser Procesrecht. Korthals Altes \& Groen 7 2015/205; Snijders \& Wendels 2009/234; beide werken met voorbeelden.

97 Zie ook art. I53 Rv (in verband met de werking van bewijsovereenkomsten), art. I57 lid 2 Rv (in verband met de dwingende bewijskracht van akten), art. I020 lid 3 Rv (in verband met de reikwijdte van de arbitrageovereenkomst) en verder een aantal artikelen die partijen het recht geven af te wijken van de gewone bevoegdheidsregels.

98 Vgl. HR ro mei I985, NJ I986/5. Zie ook HR I8 februari I994, NJ I994/765 (m.nt. H.J. Snijders): onder strijd met de openbare orde in art. Io6$_{5} \mathrm{lid} \mathrm{I} \mathrm{Rv}$ is begrepen schending van fundamentele beginselen van procesrecht. Vgl. daarmee HR 2I maart I997, NJ I998/207 (m.nt. H.J. Snijders) (Eco Swiss, tussenarrest), r.o. 4.2: 'Van strijd met de openbare orde als bedoeld in [art. 1065 lid I Rv] is slechts sprake indien - voor zover thans van belang — de inhoud of uitvoering van het vonnis strijd oplevert met dwingend recht van een zo fundamenteel karakter dat de naleving ervan niet door beperkingen van procesrechtelijke aard mag worden verhinderd. Naar Nederlands recht zal in het algemeen de enkele omstandigheid dat door de inhoud of uitvoering van het arbitrale vonnis een verbodsbepaling uit het mededingingsrecht buiten toepassing blijft, niet meebrengen dat sprake is van strijd met de openbare orde als hier omschreven.'

99 HR 28 januari 20II, NJ $2011 / 167$ (m.nt. P. van Schilfgaarde), r.o. 3.8.

IOo Snijders \& Wendels 2009/234.

IOI HR 3 oktober 20I4, ECLI:NL:HR:2014:2894. 
De vrouw verzoekt veroordeling van de man tot betaling van de achterstallige en verdere alimentatie. De man verzoekt de alimentatie op nihil te stellen. In de alimentatieovereenkomst was een beding van niet-wijziging opgenomen: '6.3. Partijen doen over en weer afstand van hun recht tot nietigverklaring, vernietiging en wijziging of ontbinding van deze overeenkomst.' De rechtbank wijst het verzoek van de vrouw toe en dat van de man af. Het hof bekrachtigt die uitspraak. Art. I:I59 lid 2 BW bepaalt dat zo'n beding vervalt als het, zoals in dit geval, is aangegaan voordat het verzoek tot echtscheiding is ingediend, tenzij die indiening plaatsvond binnen drie maanden na de alimentatieovereenkomst. In de procedure beroept de man zich op dit verval van het niet-wijzigingsbeding. Het hof gaat daaraan voorbij: 'Nu de man jarenlang de afgesproken alimentatie heeft betaald en de vrouw derhalve mocht vertrouwen op de geldigheid van het convenant, is het in strijd met de goede procesorde dat de man zich thans op het vervallen verklaren van het niet-wijzigingsbeding beroept.'

Daarover klaagt de man in cassatie en betoogt dat de rechter ingevolge art. I:I59 lid 2 $\mathrm{BW}$ geen rechtsgevolg mag verbinden aan een niet-wijzigingsbeding in een convenant dat meer dan drie maanden voor de indiening van het echtscheidingsverzoek is gesloten, ongeacht of een der partijen zich daarop heeft beroepen. Dat betoog is naar het oordeel van de Hoge Raad juist. 'Blijkens de in de conclusie van de Advocaat-Generaal onder 2.4 geciteerde passage uit de memorie van toelichting bij genoemde bepaling (Kamerstukken II I968-1969, I0 213, nr. 3, p. 24) is het, kennelijk met het oog op de ver strekkende gevolgen van een niet-wijzigingsbeding, bij wijze van "veiligheidsklep" nodig geoordeeld dat het beding vervalt indien het echtscheidingsverzoek niet binnen drie maanden na het aangaan van het convenant, waarin het beding is opgenomen, wordt ingediend. Art. I:I59 lid 2 BW moet aldus worden uitgelegd dat het niet-wijzigingsbeding door het verstrijken van de bedoelde termijn van drie maanden van rechtswege vervalt, en dat de rechter deze bepaling ambtshalve dient toe te passen. Anders dan het hof oordeelde, is derhalve niet van belang of het beroep van de man op genoemde bepaling naar maatstaven van redelijkheid en billijkheid onaanvaardbaar is, zoals het hof kennelijk heeft bedoeld in rov. 15.'

Het beding vervalt van rechtswege en geen enkele omstandigheid die samenhangt met de situatie tussen partijen kan daaraan iets veranderen. Zelfs de derogerende werking van de redelijkheid en billijkheid is uitgeschakeld. Hier zou sprake moeten zijn van een hoger belang dan het particuliere belang van deze beide partijen. De rechter dient dan op grond van dat hogere belang de bepaling ambtshalve toe te passen, wat betekent: ongeacht of daarop een beroep is gedaan. De Hoge Raad gebruikt het begrip openbare orde niet, maar dat is niet essentieel. Het effect is hetzelfde. Deze uitspraak betreft wel degelijk particuliere belangen van de partijen. Hier wordt een partij beschermd tegen het prematuur aangaan van een contractsbepaling die verstrekkende nadelige gevolgen kan hebben voor de in principe zwakkere partij. Het gaat niet zozeer om ordening van de samenleving maar om zwaarwegend geoordeelde individuele rechtsbescherming.

Wat hier gebeurt, is dat in het kader van de ambtshalve rechtstoepassing en in verband met in het bijzonder de vraag of de rechter voor die toepassing buiten de grenzen van de rechtsstrijd mag treden, een beginsel van effectieve rechtsbescherming zich laat gelden. Dat is op de keper beschouwd natuurlijk een algemeen principe van het civiele procesrecht, maar in bepaalde gevallen zijn de belangen die door die rechtsbescherming worden gediend zo zwaarwegend dat het beschikkingsrecht van individuele partijen ten aanzien van hun rechten en de daaraan verbonden 
rechtsbescherming (de partijautonomie) daarvoor moet wijken. Zo'n geval doet zich voor als per definitie de autonomie van partijen niet steeds gelijkwaardig is: er is partijautonomie en partijautonomie, om het zo maar eens te zeggen. De partijen die per definitie in hun rechtsverhouding tot de wederpartij zwak staan, verdienen in bepaalde gevallen extra waarborgen in het proces om die bescherming die het recht hun belooft effectief te laten zijn. De zojuist geciteerde uitspraak van de Hoge Raad geeft daarvan een voorbeeld. In de volgende paragraaf vinden we een ander toepassingsgebied van openbare orde.

\subsubsection{Ambtshalve vernietiging van rechtshandelingen (art. 3:40 BW)}

Door Hartkamp ${ }^{102}$ wordt verdedigd dat de rechter die constateert dat de rechtshandeling waarvan de rechtsgevolgen in het geding zijn, in strijd is met de openbare orde of goede zeden, ambtshalve en in zoverre tredend buiten de rechtsstrijd van partijen omdat op die nietigheid geen beroep is gedaan, moet beslissen dat die rechtshandeling nietig is (art. 3:40 lid I BW). Hij onderscheidt deze functie van art. $25 \mathrm{Rv}$ (door hem genoemd het tweede toepassingsgeval) van de hierboven genoemde gevallen van toepassing van die bepaling (volgens Hartkamp het eerste toepassingsgeval), omdat de rechter in het tweede toepassingsgeval niet de door partijen aangevoerde rechtsgronden aanvult. Hartkamp houdt zijn betoog in de context van de ambtshalve toepassing van EU-recht, maar wat hij voorstaat geldt volgens hem ook in de nationale context. Hartkamp ${ }^{\mathrm{I0} 3}$ breidt de categorie uit tot gevallen waarin volgens een regel van dwingend recht maar niet van openbare orde een tussen partijen bestaand beding nietig is. Maar uit het door hem daartoe genoemde arrest waarin van zo'n regel sprake was, ${ }^{104}$ blijkt duidelijk dat, omdat deze regel wel van dwingend recht maar niet van openbare orde is, het hof deze niet buiten de door de grieven omlijnde rechtsstrijd mocht toepassen. Hartkamp stelt dat dit echter niet voor de rechter in eerste aanleg zou hebben gegolden en dat deze de regel ook buiten de rechtsstrijd zou hebben moeten toepassen. Snijders ${ }^{105}$ bestrijdt de door Hartkamp bepleite ruime ambtshalve toepassing van regels waaruit absolute nietigheid voortvloeit. Hij heeft daarvoor geen overtuigend argument gevonden en dat zou er toch wel moeten zijn bij een dergelijke differentiatie van procesrecht. De opvatting van Hartkamp vindt zijns inziens ook geen enkele steun in de rechtspraak, behalve mogelijk, maar dan ten onrechte als gezegd, in een terloops en ten overvloede opgenomen zinsnede van het Vreugdenhil-arrest. ${ }^{106}$ Hartkamps repliek $^{107}$ is krachtig.

I02 Hartkamp, 2007. Daarover ontspon zich een debat: H.J. Snijders, 'Ambtshalve aanvulling van gronden van Europees recht in burgerlijke zaken herijkt', WPNR (2008) 676I, p. 54I-552; A.S. Hartkamp, 'Ambtshalve aanvullen van rechtsgronden Reactie op "Ambtshalve aanvulling van gronden van Europees recht in burgerlijke zaken herijkt” van prof. mr. H.J. Snijders in WPNR (2008) 676I', WPNR (2008) 6779, p. 977-98I en het naschrift van H.J. Snijders op p. 98I-982. Samenvattend en geactualiseerd A.S. Hartkamp, Mr. C. Assers Handleiding tot de beoefening van het Nederlands Burgerlijk Recht. 3. Vermogensrecht algemeen.Deel I.Europees recht en Nederlands vermogensrecht, Deventer: Kluwer 20I5/I28.

I03 Rede, p. 20.

I04 HR I4 november 2003, NJ 2004/I38 (m.nt. G.J.J. Heerma van Voss).

I05 WPNR 676I, p. 545 .

Io6 HR 3 december 2004, NJ 2005/II8 (m.nt. M.R. Mok).

IO7 WPNR (2008) 6779, p. 979. 
'De niet-inachtneming van vormvoorschriften leidt in beginsel tot nietigheid (art. 3:39 BW). Vormvoorschriften lijken mij niet van dien aard dat steeds van bepalingen van openbare orde sprake is. Toch denk ik dat een rechter menig vormvoorschrift ambtshalve zal toepassen; men denke aan het geval dat de eiser een vordering baseert op een cessie waarvan, naar uit het dossier kan worden afgeleid (maar anders dan door een beroep daarop zijdens de gedaagde), geen akte is opgemaakt. Een ander argument leveren de nietigheden in het nieuwe arbeids- en huurrecht van Boek 7 BW op, waar de term "nietigheid" bewust is gekozen om aan te geven dat de dwingende bepaling ambtshalve door de rechter kan worden toegepast en dat beide partijen een beroep op de bepaling kunnen doen, terwijl duidelijk is dat niet steeds van een bepaling van openbare orde sprake is. In de memorie van toelichting bij het wetsontwerp dat tot titel 7.10 heeft geleid wordt zelfs gesteld dat dit voor alle nietigheden bedoeld in art. 3:40 lid 2 geldt', aldus zijn reactie. In zijn naschrift blijft Snijders bij zijn bestrijding van deze opvatting.

Het komt mij voor dat beiden gelijk hebben. Snijders heeft gelijk dat de opvatting van Hartkamp niet past in de huidige leer ten aanzien van de aanvulling van rechtsgronden. Die houdt in dat alleen in gevallen waarbij de rechtsgrond van openbare orde is (of van daarmee gelijk te stellen karakter, zie de vorige paragraaf), de rechter deze zal moeten toepassen, ook al treedt hij buiten de rechtsstrijd. Voor het nationale Nederlandse recht ${ }^{\text {108 }}$ erkent Hartkamp datook in zijn Asser/Hartkamp 3 -I, ${ }^{\text {Io9 }}$ verwijzend naar HR I6 januari 2009, NJ 2009/54 (Gemeente Heerlen/Whizz), waarin wordt overwogen:

'Onderdeel I.I is gebaseerd op de opvatting dat art. 8I EG (in het licht van de rechtspraak van het HvJ EG) meebrengt dat de rechter, ook als hij daarmee buiten de grenzen van de rechtsstrijd zou treden, zo nodig ambtshalve de nietigheid van een (beding in een) overeenkomst wegens ongeoorloofde verhindering van de mededinging zou moeten vaststellen, althans ambtshalve onderzoek daarnaar zou moeten instellen. Wat er ook zij van de juistheid van die opvatting met betrekking tot art. 8I EG, zulks gaat in ieder geval niet op in het onderhavige geval aangezien - zoals het hof in rov. 5.I, in cassatie onbestreden, heeft vastgesteld - hier geen sprake is van een beperking van de handel tussen lidstaten, zodat niet art. 8I EG doch alleen art. $6 \mathrm{Mw}$ aan de orde is. Art. $6 \mathrm{Mw}$ bevat evenwel geen recht van openbare orde dat de rechter, ook als hij daarmee buiten de grenzen van de rechtsstrijd zou treden, ambtshalve moet toepassen.'

Maar Hartkamp heeft gelijk dat het niet aangaat een absolute nietigheid die volgt uit een wetsbepaling die niet een regel van openbare orde bevat, in het proces te negeren enkel omdat die nietigheid geen onderdeel uitmaakt van de rechtsstrijd. De bakens zouden op dit punt verzet moeten worden. Het is naar mijn mening wel degelijk de taak van de rechter om die nietigheid aan de orde te stellen en partijen erop te wijzen dat de rechter in het licht daarvan niet verantwoord zou handelen door te doen alsof zijn neus bloedt. Op die wijze zal het gegeven zonder twijfel deel worden van het debat, ook al wordt het misschien niet expliciet overgenomen in de grondslagen van de partij die bij nietigheid baat heeft. Het is belangrijker dat de partijen ermee geconfronteerd zijn en daarover hun standpunt hebben kunnen uiten dan dat een partij de grond formeel tot de hare maakt. Dat is trouwens ook het recept

Io8 Zie voor het EU-recht de volgende paragraaf.

Io9 Asser/Hartkamp 3-I 2015/I28. 
indien de rechter ambtshalve buiten de rechtsstrijd rechtsgronden van openbare orde zou gaan toepassen: eerst voorleggen om partijen daarop te laten reageren.

\subsubsection{EU-recht}

In 20II heeft Hartkamp in zijn preadvies voor onze vereniging het onderwerp in het kader van het EU-recht besproken. ${ }^{\text {IIO }}$ Een korte schets van de actuele stand van zaken daarom. ${ }^{\text {III }}$

De belangrijkste vraag die in het kader van de ambtshalve toepassing van EUrecht - en dan met name mededingingsrecht en de consumentenbescherming speelde, is of voor ambtshalve toepassing het EU-recht dezelfde status heeft als het nationale recht van openbare orde. Immers, indien dat moet worden aangenomen, heeft de rechter, ongeacht de hem door art. $24 \mathrm{Rv}$ opgelegde binding aan de grondslagen van vordering en verweer, de plicht de grenzen van de rechtsstrijd te verleggen door ruimte te scheppen voor een op die ambtshalve toepassing gericht debat op basis van de in het geval toepasselijke regels van EU-recht. Het is nu wel duidelijk dat die vraag zowel voor het mededingingsrecht (met name het kartelverbod van art. IoI VWEU - voorheen art. 8I EG) als de rechtsbescherming van consumenten op grond van Richtlijn 93/I3/EEG bevestigend moet worden beantwoord.

Aan de orde zijn in deze materie het gelijkwaardigheidsprincipe: waar de rchter in zaken van nationaal recht bevoegd of verplicht is tot aanvulling van rechtsgronden, moet hij dat ook zijn in zaken waarin EU-recht van toepassing is, alsook het effectiviteitsbeginsel (doeltreffendheidsbeginsel): nationale procesrechtelijke voorschriften mogen het in de praktijk niet onmogelijk of uiterst moeilijk maken om een aan het EU-recht ontleend recht uit te oefenen, wat in ons geval erop neerkomt dat de rechter nationale procesrechtelijke belemmeringen moet doorbreken - denk aan overschrijding van de grenzen van de rechtsstrijd - indien de aard van het EUrecht zo fundamenteel van aard is dat zulks geboden is op grond van het effectiviteitsbeginsel. In dit laatste geval pleegt het HvJ EU de desbetreffende regels(s) van EU-recht aan te merken als van openbare orde. Hierna wordt de werking van het effectiviteitsbeginsel in vogelvlucht beschouwd.

Voor wat betreft het kartelverbod stelde het Van Schijndel-arrest ${ }^{112}$ het gemeenschapsrecht ten aanzien van de bevoegdheid en plicht van de rechter tot ambtshalve toepassing op grond van art. $25 \mathrm{Rv}$ op één lijn met het nationale recht. Wel ambtshalve toepassen was de boodschap, maar niet wanneer de rechter de hem passende lijdelijkheid zou moeten verzaken door buiten de rechtsstrijd van partijen te treden en zich te baseren op andere feiten en omstandigheden dan die welke de partij die bij

IIo A.S. Hartkamp, De horizontale werking van het (primaire) recht van de Europese Unie en het Nederlandse vermogensrecht, preadvies voor de Vereniging voor de vergelijkende studie van het recht van België en Nederland, Den Haag: Boom Juridische uitgevers 20II, p. 348-358.

III Ik verwijs voor de materie voorts naar Hartkamp, 20I5/I24-I30. Ancery 20I2, hfdst. 8; H.B. Krans, Nederlands burgerlijk procesrecht en materieel EU-recht, Serie Burgerlijk Proces en Praktijk, Deventer: Kluwer 20Io, hfdst. 5; alle met verdere literatuur. Bij De Groot 20I2/3.7.2 is veel literatuur vermeld. Zie ook de hierboven in noot 102 vermelde discussie tussen Snijders en Hartkamp n.a.v. diens Nijmeegse rede.

II2 HvJ EG I4 december I995, C-430/93 en C-43I/93, NJ I997/II6 (m.nt. P.J.Slot en Snijders onder NJ I997/II8) (Van Schijndel en Van Veen). 
de toepassing van de bepaling belang heeft aan haar vordering ten grondslag heeft gelegd. Het effectiviteitsbeginsel stond niet aan een dergelijke beperking in de weg. De Hoge Raad leidde in 1997 (in het tussenarrest in de zaak Eco Swiss ${ }^{113}$ ) uit het Van Schijndel-arrest van het HvJ af dat het mededingingsrecht niet van openbare orde was.

De ontwikkelingen op het terrein van het kartelrecht stonden niet stil. Het kartelrecht werd al gelijkgesteld met nationaal recht van openbare orde in het Eco Swissarrest van $1999,{ }^{\mathrm{II}}$ dus niet zo lang na het Van Schijndel-arrest. De rechter die een vordering tot vernietiging van een arbitraal vonnis op grond van strijd met nationale regels van openbare orde moet toewijzen, moet dat ook doen ingeval een dergelijke vordering is gebaseerd op schending van het in art. IoI lid I VWEU neergelegde verbod. ${ }^{15}$ Dit was mijns inziens toch wel een duidelijke vingerwijzing ten aanzien van het karakter van het kartelrecht. De partijautonomie, basis bij uitstek van de arbitrage, moet daarvoor wijken. ${ }^{116}$ Met name in het Manfredi-arrest ${ }^{117}$ wordt die ontwikkeling in wezen voltooid wanneer wordt overwogen dat de artikelen (thans) IOI en IO2 VWEU bepalingen van openbare orde zijn die door de nationale rechter ambtshalve moeten worden toegepast, waartoe, mijns inziens dus alleszins begrijpelijk, ${ }^{118}$ naar het Eco Swiss-arrest wordt verwezen. Intussen had de Hoge Raad zich in het Vreugdenhil-arrest van $2004^{\text {II }}$ laten ontvallen dat het hof '- in cassatie terecht niet bestreden - [heeft] geoordeeld dat het de nietigheid wegens strijd met het mededingingsrecht van de tussen thans verweerster in cassatie als veilingbedrijf en thans eiseres tot cassatie als importeur gesloten overeenkomsten inzake het veilingklaar maken van importproducten, voor zover nodig ambtshalve moet vaststellen'. Dat heeft overigens niets terloops, want Advocaat-Generaal Keus had betoogd dat en waarom de opvatting van het hof onjuist was en van dat betoog nam de Hoge Raad afstand met dat in zijn spraakgebruik veelbetekenende woordje 'terecht' maar zonder verdere motivering. Maar wat daarvan ook zij, in het T-Mobile-arrest ${ }^{120}$ heeft het Hof van Justitie klare wijn geschonken: 'Om te beginnen zij eraan herinnerd dat artikel 81 EG rechtstreekse gevolgen teweegbrengt in de betrekkingen tussen particulieren en voor de justitiabelen rechten doet ontstaan die de nationale rechter dient te handhaven. Voorts is het een voor de veruulling van de taken van de Europese Gemeenschap onontbeerlijke bepaling van openbare orde, die door de nationale rechter ambtshalve moet worden toegepast', waartoe het hof verwijst naar arresten Eco Swiss en Manfredi. Daarom was de overweging in het Manfredi-arrest bepaald geen 'slip of the pen'. ${ }^{\text {I2I }}$

II3 HR 2I maart I997, NJ I998/207 (m.nt. H.J. Snijders) (Eco Swiss, tussenarrest), r.o. 4.4.

II4 HvJ EG I juni I999, C-I26/97, NJ 2000/339.

II5 Art. 1065, lid I, aanhef en onder 2, Rv.

II6 Terecht mijns inziens betoogt Ancery 20I2/8.2.I dat het Renault-arrest (HvJ EG II mei 2000, $\mathrm{C}-38 / 98, \mathrm{NJ} 2003 / 627$ (m.nt. P. Vlas)) in dit verband niet tot duidelijke conclusies leidt. De uitspraak betrof een exequatur-geschil onder het EEX en beslist werd dat schending van art. I02 VWEU in het te erkennen vonnis geen grond opleverde om de erkenning te weigeren.

II7 HvJ EG I3 juli 2006, C-295-298/04, NJ 2007/34 (m.nt. M.R. Mok), overweging 3I (welke overweging niet in de $\mathrm{NJ}$ is opgenomen).

II8 Anders onder meer A-G Keus voor het hierna te noemen Vreugdenhil-arrest van de HR en Ancery 2012/8.2.I, die vindt dat in het Eco Swiss-arrest het HvJ allesbehalve duidelijk heeft gemaakt dat art. IOI VWEU van openbare orde zou zijn 'in de zin van ambtshalve aanvullen van rechtsgronden'.

II9 HR 3 december 2004, NJ 2005/II8 (M.R. Mok).

I20 HvJ EG C-8/08, NJ 2009/432 (M.R. Mok).

I2I Aldus Snijders WPNR (2008) 676r. Daartegen Hartkamp in zijn reactie daarop in WPNR (2008) 6779 . 
Intussen is de beslissing van het Hof van Justitie in het Van Schijndel-arrest niet van de baan. In het Van der Weerd-arrest van 2007 is zij geciteerd, maar daarin betrof het een geval waarin geen sprake was van EU-recht van openbare orde (Richtlijn 85/5II/EEG betreffende de bestrijding van mond-en-klauwzeer) en bovendien partijen zelf de mogelijkheid hadden maar niet hadden benut om het EU-recht in de procedure aan de orde te stellen. Het effectiviteitsbeginsel eiste dus niet doorbreking van de grenzen van de rechtsstrijd. ${ }^{122}$ Het belang van dit arrest is dat het Hof van Justitie voor het EU-recht in het algemeen de door het nationale procesrecht gestelde grenzen van de rechtsstrijd op gelijke voet met de nationale rechter blijft respecteren, tenzij het effectiviteitsbeginsel in verband met het fundamentele karakter van het EU-recht in kwestie anders meebrengt.

Voor de nationale rechter die ambtshalve EU-recht van openbare orde moet toepassen en daartoe in de door partijen gevormde grondslagen van vordering c.q. verweer onvoldoende feitelijke basis vindt, geldt de verplichting het debat te heropenen om partijen in de gelegenheid te stellen de feitelijke grondslagen in het licht van die rechtstoepassing aan te vullen. Hiermee maak ik de brug naar het arrest Heesakkers/Voets van de Hoge Raad waarin de ambtshalve toepassing van Richtlijn 93/I3/EEG inzake de consumentenbescherming tegen oneerlijke bedingen wordt uitgewerkt. ${ }^{23}$ Het arrest beredeneert waarom hier de openbare orde in het geding is, het is een typisch en prachtig voorbeeld van de Hoge Raad die op het punt van de ambtshalve toepassing procesrecht vormt. Ik sluit daarom met een weergave van de belangrijkste overwegingen in dit arrest de bespreking van het EU-recht af.

'3.6.I. Volgens de rechtspraak van het HvJ EU gaat het hier om een onderzoek met betrekking tot recht dat gelijkwaardig is aan de nationale regels van openbare orde. In HvJ EU 30 mei 2013, C-488/II (Asbeek Brusse en De Man Garabito), is in dit verband als volgt overwogen:

"42. Aangaande de uitvoering van die verplichtingen door een nationale rechter in hoger beroep moet eraan worden herinnerd dat, bij gebreke van een Unierechtelijke regeling, de regels met betrekking tot hogere beroepen die ertoe strekken de rechten te beschermen die de justitiabelen aan het Unierecht ontlenen, krachtens het beginsel van procedurele autonomie van de lidstaten een zaak van de interne rechtsorde van die staten zijn. Deze regels mogen evenwel niet ongunstiger zijn dan die welke voor soortgelijke situaties krachtens intern recht gelden (gelijkwaardigheidsbeginsel) en de uitoefening van de door de rechtsorde van de Unie verleende rechten in de praktijk niet onmogelijk of uiterst moeilijk maken (doeltreffendheidsbeginsel) (zie in die zin arresten Banco Español de Crédito, punt 46, en Banif Plus Bank, punt 26).

43. Wat betreft het gelijkwaardigheidsbeginsel (...) moet erop worden gewezen dat (...) artikel 6, lid I, van de richtlijn een dwingende bepaling is. Voorts moet worden opgemerkt dat volgens de rechtspraak van het Hof deze richtlijn in haar geheel een maatregel vormt die onontbeerlijk is voor de vervulling van de taken van de Unie en in het bijzonder

I22 HvJ EG 7 juni 2007, C-222-225/05, NJ 2007/39I (m.nt. M.R. Mok) (Van der Weerd).

I23 HRI3 september 20I3, ECLI:NL:HR:20I3:69I, NJ 20I4/274 (m.nt. H.B. Krans). Zie naar aanleiding hiervan het rapport van De Rechtspraak, Ambtshalve toetsing II, Herzien rapport van de LOVCK werkgroep, november 2014, te vinden op https://www.rechtspraak.nl/Procedures/Landelijke-regelingen/Sector-civiel-recht/ Pages/rapport-Ambtshalve-toetsing-van-Europees-consumentenrecht.aspx (geraadpleegd augustus 2015) waarin een handleiding wordt gegeven aan de rechters. 
voor de verbetering van de levensstandaard en van de kwaliteit van het bestaan binnen de gehele Unie (zie arrest van 4 juni 2009, Pannon GSM, C-243/08, Jurispr. blz. I-47I3, punt 26, en arrest Banco Español de Crédito, punt 67).

44. Het Hof heeft overigens geoordeeld dat, gelet op de aard en het gewicht van het openbare belang waarop de door de richtlijn aan de consument verzekerde bescherming berust, artikel 6 van deze richtlijn moet worden beschouwd als een norm die gelijkwaardig is aan de nationale regels die in de interne rechtsorde als regels van openbare orde gelden (zie arrest van 6 oktober 2009, Asturcom Telecomunicaciones, C-40/08, Jurispr. blz. I-9579, punt 52, en beschikking van 16 november 2010, Pohotovost', C-76/Io, Jurispr. blz. I-II557, punt 50). Deze kwalificatie is van toepassing op alle bepalingen van de richtlijn die onontbeerlijk zijn voor de verwezenlijking van het met artikel 6 beoogde doel.

45. Hieruit volgt dat de nationale rechter, wanneer hij op grond van de nationale regels van procesrecht bevoegd is ambtshalve de geldigheid van een rechtshandeling te toetsen aan nationale regels van openbare orde, hetgeen volgens de in de verwijzingsbeslissing verstrekte gegevens in het Nederlandse stelsel van rechtspleging het geval is voor de rechter in hoger beroep, deze bevoegdheid ook moet uitoefenen om ambtshalve te beoordelen of een onder de richtlijn vallend contractueel beding uit het oogpunt van de daarin gegeven criteria mogelijk oneerlijk is.

(...)

48. Volgens artikel 6 , lid I, eerste zinsnede, van de richtlijn moeten de lidstaten bepalen dat oneerlijke bedingen 'onder de in het nationale recht geldende voorwaarden' de consument niet binden.

49. Het Hof heeft die bepaling aldus uitgelegd dat de nationale rechter alle consequenties moet trekken die volgens het nationale recht voortvloeien uit de vaststelling van het oneerlijke karakter van het betrokken beding, teneinde zich ervan te vergewissen dat de consument niet is gebonden aan dit beding (arresten Banco Español de Crédito, punt 63, en Banif Plus Bank, punt 27). In dit verband heeft het Hof aangegeven dat de nationale rechter een contractueel beding dat hij oneerlijk acht, buiten toepassing moet laten, tenzij de consument zich hiertegen verzet (zie arrest Pannon GSM, reeds aangehaald, punt 35)."

3.6.2. In laatstgenoemd arrest heeft het HvJ EU voor recht verklaard (onder 53) dat:

"- de nationale rechter, wanneer bij hem door een verkoper tegen een consument een vordering is ingesteld over de uitvoering van een overeenkomst en hij op grond van de nationale regels van procesrecht bevoegd is ambtshalve na te gaan of het aan de vordering ten grondslag liggende beding in strijd is met nationale regels van openbare orde, op dezelfde wijze ambtshalve moet toetsen of dat beding uit het oogpunt van de in deze richtlijn gegeven criteria oneerlijk is, wanneer hij heeft vastgesteld dat het beding binnen de werkingssfeer van de richtlijn valt

- de nationale rechter, wanneer hij op grond van de nationale regels van procesrecht bevoegd is ambtshalve over te gaan tot vernietiging van een beding dat in strijd is met de openbare orde of met een dwingende wetsbepaling waarvan de strekking deze sanctie rechtvaardigt, in beginsel, na partijen de gelegenheid te hebben gegeven op tegenspraak hun standpunt kenbaar te maken, ambtshalve moet overgaan tot vernietiging van een contractueel beding waarvan hij het oneerlijke karakter uit het oogpunt van de in de richtlijn gegeven criteria heeft vastgesteld."

3.6.3. Het vorenstaande brengt voor het Nederlandse recht mee dat de appelrechter is gehouden ambtshalve na te gaan of een beding uit het oogpunt van de in Richtlijn 93/13 gegeven criteria oneerlijk is, ook indien hij daarbij buiten het door de grieven ontsloten gebied moet treden. Volgens het Nederlands appelprocesrecht behoort de rechter immers recht van openbare orde in beginsel ook toe te passen buiten het door de grieven ontsloten gebied, met dien verstande dat hij de grenzen van de rechtsstrijd van partijen 
dient te respecteren. Hij is dus niet tot dit onderzoek gehouden als tegen de toe- of afwijzing van de desbetreffende vordering in hoger beroep niet is opgekomen en hij derhalve als appelrechter niet bevoegd is om over die vordering een beslissing te geven.

3.7.I. Richtlijn 93/13 is niet rechtstreeks van toepassing in de Nederlandse rechtsorde. Een richtlijnconforme uitleg van het Nederlandse recht brengt echter mee dat de Nederlandse rechter op grond van art. 6:233 BW gehouden is het hiervoor bedoelde onderzoek ambtshalve te verrichten ingeval Richtlijn 93/13 die verplichting meebrengt.

3.7.2. In dit verband is van belang dat uit art. 6 lid I van Richtlijn 93/I3 de verplichting van de Lidstaten voortvloeit om een oneerlijk beding niet-bindend te oordelen. Het HvJ EU heeft deze bepaling aldus uitgelegd dat de nationale rechter die heeft vastgesteld dat een beding in een overeenkomst tussen een verkoper en een consument oneerlijk is, zonder meer verplicht is dat beding voor de consument buiten toepassing te laten ( $\mathrm{HvJ}$ EU 30 mei 2013, C-488/II (Asbeek Brusse en De Man Garabito), punt 55-60).

3.7.3. Voor het Nederlandse recht betekent het vorenstaande dat indien de rechter vaststelt dat een beding oneerlijk is in de zin van Richtlijn 93/13, hij gehouden is het beding te vernietigen.

3.8. Hetgeen hiervoor in 3.5.I-3.7.3 is overwogen ten aanzien van de rechterlijke taak, lijdt uitzondering indien de consument zich ertegen verzet dat de rechter een contractueel beding dat hij oneerlijk oordeelt, buiten toepassing laat (HvJ EU 30 mei 2013, C-488/II (Asbeek Brusse en De Man Garabito), punt 49).

De Hoge Raad ziet aanleiding om met betrekking tot de gehoudenheid tot ambtshalve onderzoek nog het volgende te overwegen. Indien de rechter over de daartoe noodzakelijke gegevens, feitelijk en rechtens, beschikt om te vermoeden dat een overeenkomst onder het bereik van Richtlijn 93/13 valt en een beding bevat dat oneerlijk is in de hiervoor genoemde zin, dient hij daarnaar onderzoek te doen, ook indien daarop gerichte stellingen niet aan de vordering of het verweer ten grondslag zijn gelegd. Dit geldt zowel in eerste aanleg als in hoger beroep, wat het laatste betreft met inachtneming van hetgeen hiervoor in 3.6 .3 is overwogen.

Staan de relevante feiten niet alle vast, dan zal de rechter de instructiemaatregelen moeten nemen die in dit verband nodig zijn om de volle werking van de Richtlijn 93/13 te verzekeren, wat betreft zowel de toepasselijkheid van die richtlijn, als de mogelijke oneerlijkheid van het beding.

De rechter dient het beginsel van hoor en wederhoor in acht te nemen. Hij dient partijen in de gelegenheid te stellen zich over een en ander uit te laten en, zo nodig, hun stellingen daaraan aan te passen.

3.9.2. Ook in verstekzaken zal de rechter dit onderzoek ambtshalve moeten verrichten, in dat geval in het kader van art. $139 \mathrm{Rv}$, nu het hier gaat om recht dat gelijkwaardig is aan de nationale regels van openbare orde (vgl. de hiervoor in 3.5.I aangehaalde uitspraak van HvJ EU in Banco Español de Crédito, punt 48). Dat onderzoek dient dan plaats te vinden aan de hand van de dagvaarding. Ook in dat geval zal de rechter eventueel de instructiemaatregelen moeten nemen die nodig zijn om de volle werking van Richtlijn 93/I3 te verzekeren. Voorts dient hij ook in dat geval het beginsel van hoor en wederhoor in acht te nemen en eiser in de gelegenheid te stellen zich terzake nader uit te laten en, zo nodig, zijn stellingen aan te passen.

3.9.3. Voor de cassatieprocedure betekent het hiervoor overwogene dat met succes kan worden geklaagd dat de feitenrechter het hiervoor bedoelde onderzoek achterwege heeft gelaten indien onbegrijpelijk is dat de in de procedure gebleken gegevens hem geen aanleiding hebben gegeven tot het hiervoor in 3.9.I bedoelde vermoeden. 


\section{$4 \quad$ Een paar afrondende opmerkingen}

Hoezeer men ook hecht aan het primaat van de partijen (de partijautonomie), niet meer ontkend kan worden dat partijen èn rechter de verantwoordelijkheid voor de kwaliteit van het proces en dus ook voor de kwaliteit van de uitkomst dragen. ${ }^{\mathrm{I} 24}$ Dat betekent niet dat het proces een 'Arbeitsgemeinschaft' van partijen en rechter is waarin samen wordt toegewerkt naar een door allen beoogd resultaat. Het betekent wel dat alle deelnemers, partijen èn rechter, vanuit hun eigen positie ertoe bijdragen dat het proces voldoet aan de eisen van fairness en de rechter in staat stellen te komen tot een zowel feitelijk als juridisch goed gefundeerde beslissing. ${ }^{125}$ Een eerlijk proces dus - op zichzelf al een doel ${ }^{126}$ - waarin alle voor de beslissing van het geschil relevante informatie zoveel mogelijk op tafel komt. Partijen moeten daarom elkaar (in verband met de kwaliteit van het debat) en de rechter (in verband met de kwaliteit van diens beslissing) naar volledigheid en waarheid de informatie verschaffen die daartoe nodig is, zoals bijvoorbeeld art. 2I Rv voorschrijft. De rechter mag dat van partijen eisen - hij heeft daarvoor ook voldoende instrumenten. ${ }^{127} \mathrm{De}$ rechter moet dat ook kunnen doen om zijn verantwoordelijkheid waar te kunnen maken. Dat betekent dat de rechter niet alleen op processueel terrein maar ook inhoudelijk zich mengt in het debat, om het zo te zeggen. Over de ruimte die hem daarin toekomt, ging het in dit preadvies.

De rechter behoort vanuit dit oogpunt de vrijheid te hebben om het debat te sturen en dat zo nodig te heropenen in het licht van de rechtsregels die zijns inziens dienen te worden toegepast om een aanvaardbare beslissing in het geschil te kunnen geven, maar op basis waarvan partijen hun debat niet hebben gevoerd. De rechter moet, uitgaande van de op de vordering c.q. het verweer toepasselijke rechtsnorm, de volledigheid en juistheid van de gestelde rechtsfeiten aan de orde kunnen stellen. Een evident verweer wordt niet gevoerd, een feitelijke constellatie in de stukken wordt verkeerd gekwalificeerd en leidt tot toepassing van een andere norm, het verweer is daarop niet afgestemd. Dat zijn allemaal situaties die zich kunnen voordoen. Aanvulling van rechtsgronden kan niet zonder herkwalificatie van feiten. De rechter hoort dat te kunnen bespreken, aan de orde te kunnen stellen, ook als het gaat om recht dat niet van openbare orde is. De rechter heeft de plicht ervoor te zorgen dat hij een zowel feitelijk als juridisch verantwoorde basis voor zijn beslissing heeft, een basis met kloppende alternatieven, niet met vraagtekens die leiden tot verrassingsbeslissingen. Partijen mogen niet worden verrast, maar behoren te weten wat ze kunnen verwachten. Voor het overige zou de rechter op dit punt geen belemmeringen mogen worden opgelegd, anders dan die door de goede procesorde worden geëist. De goede procesorde zal

I24 Of men dat nu een gezamenlijke verantwoordelijkheid noemt (zoals mijn mede fundamentele herbezinners en ik het hebben geformuleerd in onze rapporten) of een samen gedragen verantwoordelijkheid is niet zo belangrijk.

I25 Vgl. de kabinetsreactie op het Eindraport Fundamentele Herbezinning Nederlands Burgerlijk Procesrecht (=Asser, Groen \& Vranken 2006), Kamerstukken II 2006/07, 30 95I, nr. I, nr. 25 (m.i. wat te neutraal) 'dat elk van partijen in het civiele proces vanuit zijn eigen belang en verantwoordelijkheid het nodige doet om de rechter in staat te stellen tot een uitspraak te komen'.

I26 Vgl. in deze zin De Bock 20Ir/2.5 (p. 65).

I27 Bijv. art. 22 (bevel tot het geven van inlichtingen), art. $88 \mathrm{Rv}$ (inlichtingencomparitie). 
echter niet snel aan een rechtens juiste beslissing in de weg staan. Het proces blijft immers óók middel tot het doel, met dien verstande dat een koerswijziging het proces in een laat stadium zozeer overhoop kan halen dat het daarmee beoogde resultaat niet meer kan worden bereikt op grond van een, met het oog op de mogelijkheden van een eerlijk debat en verantwoord onderzoek, behoorlijk proces. Voor dit alles is, zoals mijns inziens uit de rechtspraak blijkt, nu al voldoende ruimte.

Het voorgaande is geenszins strijdig met het uitgangspunt van het civiele proces dat de rechter zich houdt aan zijn opdracht: beslissing van het hem voorgelegde, door de over en weer geponeerde feitelijke stellingen omlijnde geschil. Zijn analyse van het geschil moet gebeuren op basis van wat de partijen aan (rechts)feiten hebben gepresenteerd; de door de eiser respectievelijk verweerder daartoe gemaakte keuzen heeft de rechter in principe te respecteren. Enkel in de gevallen dat sprake is van recht van openbare orde (of: superdwingend recht) behoeft de rechter die keuzen niet te volgen en zal hij ook op het feitelijke vlak de leiding moeten overnemen. Maar ook dan blijft het proces gaan over het geschil van partijen dat aan de rechter is voorgelegd (of het geschil voorzover dat in hoger beroep nog aan de orde is). Onderscheiden moet immers worden tussen het geschil en de rechtstoepassing, hoe lastig soms ook, zoals hierboven is gebleken. Het eerste blijft een verantwoordelijkheid van partijen; tot de verantwoordelijkheid van de rechter behoort de beslissing van dat geschil met toepassing van de regels die rechtens van toepassing zijn. 